\title{
12. SEDIMENTOLOGY, MINERALOGY, AND GEOCHEMISTRY OF HYDROTHERMAL DEPOSITS FROM HOLES 424, 424A, 424B, AND 424C (GALAPAGOS SPREADING CENTER)
}

\author{
M. Hoffert, ${ }^{1}$ A. Person, ${ }^{2}$ C. Courtois,${ }^{3}$ A. M. Karpoff,${ }^{1}$ and D. Trauth ${ }^{1}$
}

\section{INTRODUCTION}

On Leg 54 of the Deep Sea Drilling Project, four holes were drilled at Site 424 , about $20 \mathrm{~km}$ south of the Galapagos Spreading Center (GSC) (Figure 1). The holes were situated less than 300 meters from each other on a north-south line in water about 2700 meters deep, near $0^{\circ} 35^{\prime} \mathrm{N}$ and $86^{\circ} 07^{\prime} \mathrm{W}$. The age of the basaltic basement here is about 0.60 to 0.62 m.y. (Hekinian et al., 1978). This particular site was chosen because a major sea-floor hydrothermal system, with associated sediments, occurs in this area (Klitgord and Mudie, 1974; Lonsdale, 1977).

The sampling area is characterized by small mounds, 5 to 20 meters high, parallel to the axis of the GSC, and is associated with heat flow (Williams et al., 1974; Crane and Normark, 1977). The mounds are arrayed above faults in the basaltic basement (Lonsdale, 1977).

The regional sedimentary blanket is about 30 meters thick. Bottom photographs made of the mounds by Corliss et al. (1978) show that they consist of black crusts with light brown and orange patches and that some are partially covered by organisms (e.g., bivalves).

Holes 424 and $424 \mathrm{~A}$ were located as precisely as possible on two mounds. The sediments are respectively 31 and 34 meters thick. Hole 424B is sampled about 300 meters north of Hole 424 in an area between two mounds. The sedimentary thickness is $\mathbf{3 8}$ meters. Finally, Hole $424 \mathrm{C}$, also away from any mounds, was only partially sampled; only 7 meters of sediments in the topmost core was recovered. The sedimentary thickness is 30.5 meters.

\section{LITHOLOGIC DESCRIPTION}

Visual observation of the sedimentary columns of the four holes allowed us to distinguish three main types of deposits on the basis of their color and appearance:

Type I: Black granular material containing hard black fragments whose size may exceed $1 \mathrm{~cm}$. The granular material is a mixture of manganese

\footnotetext{
' Centre de Sédimentologie et Géochimie de la Surface, Institut de Géologie, 1 rue Blessig, 67084 Strasbourg, France.

${ }^{2}$ Laboratoire de Géochimie des Roches Sédimentaires, Université Paris-Sud, Faculté des Sciences, 91405 Orsay, France.

${ }^{3}$ Laboratoire de Géologie Dynamique, Université de Paris VI, 4 place Jussieu, 75230 Paris Cedex, France.
}

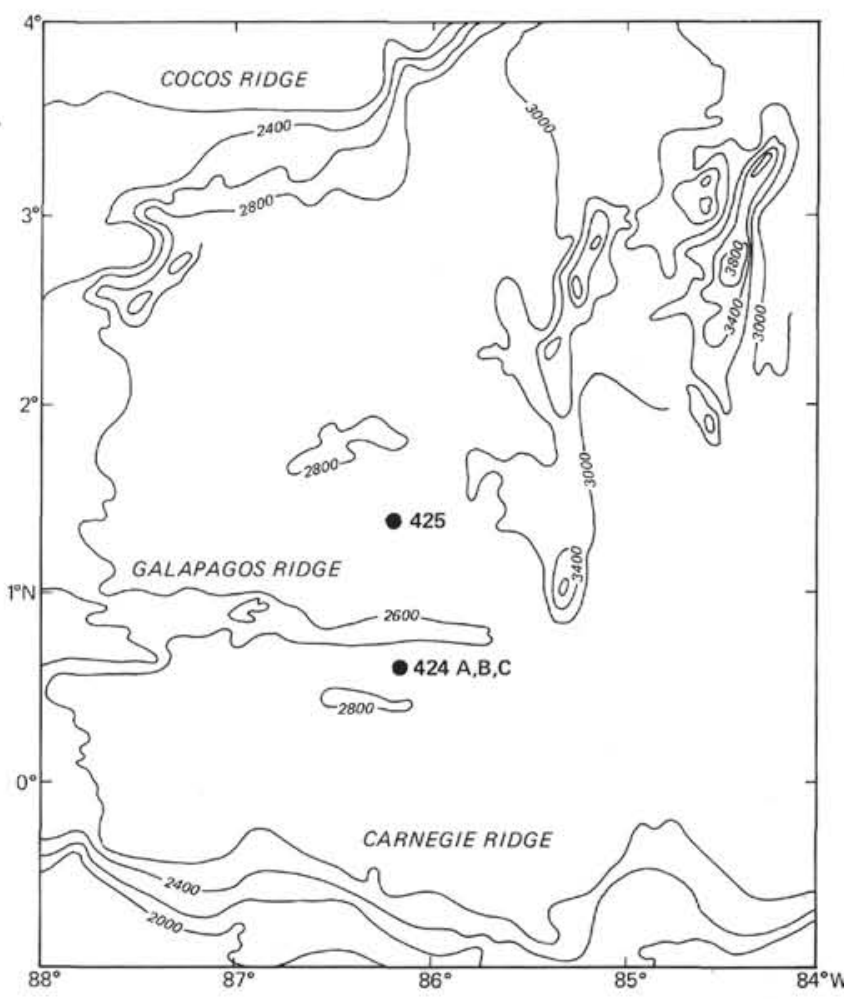

Figure 1. Locationing of DSDP Holes 424A, B, C, and 425 (depths in meters).

oxides and clay minerals. The black fragments are pure manganese oxides.

Type II: Dark green to black clay-rich mud consisting of rather small granules (about 1 $\mathrm{mm})$. The color of these particles varies between a dark green and a brown color, but is usually green.

Type III: Fine, homogeneous gray or greenish gray silicareous foraminifer nannofossil ooze, which may contain minor manganese nodules, blackish layers, and chalk fragments.

\section{Hole 424}

The entire Core 1 is black (N 2) or dark grey (N 3). The sediment, which is rough, consists of granules with small black particles interspersed. The average granule size is about a few millimeters. Some of the grains show fresh cracks. The apparent graded bedding results from 
drilling disturbance. Thus, it is impossible to define the initial texture. We shall design this sediment as "type I.' A small number of black fragments stand out by their length (up to $2 \mathrm{~cm}$ ). They seem to be remains of organisms or burrowing traces replaced by Fe-Mn oxides (Hekinian et al., 1978).

Interval $2-1,0 \mathrm{~cm}$ to $2-3,133 \mathrm{~cm}$

This unit is a greenish black to olive-black sediment composed of granules of about $1 \mathrm{~mm}$ in size. Their smaller grain size, as well as color, sets this type of sediment apart from type I. Furthermore, the black fragments are very scarce and much localized. We shall define this sediment as "type II." Because of a gap in the sampling between types I and II, it is difficult to determine the exact transition from one type to the other. Nevertheless, greenish granules have been observed aboard the ship in Sample 424-1,CC. This argues for a progressive transition between the two types.

\section{Interval $2-3,133 \mathrm{~cm}$ to $2-4,25 \mathrm{~cm}$}

This interval is separated from the preceding one by a clean contact. The sediment which composes it is characterized by its grayish olive-green color and its fine and homogeneous aspect. It is similar to a pelagic ooze. We shall define this deposit as "type III." The lower limit of this unit is ill marked.

\section{Interval $2-4,25 \mathrm{~cm}$ to $2-4,110 \mathrm{~cm}$}

This is a type II sediment. Its lower limit is not sharply defined. Two nodules of about $1 \mathrm{~cm}$ in diameter are present at 2-4, $33 \mathrm{~cm}$ and $2-4,100 \mathrm{~cm}$.

\section{Interval 2-4, $110 \mathrm{~cm}$ to the Base of Core 2}

This is a type III sediment. Nevertheless, this section contains patches and streaks of type II sediments, particularly at intervals $2-5,0 \mathrm{~cm}$ to $20 \mathrm{~cm}$ and $2-5,95 \mathrm{~cm}$ to $110 \mathrm{~cm}$.

\section{Interval $3-1,0 \mathrm{~cm}$ to $3-1,50 \mathrm{~cm}$}

This is a type II unit. The lower limit is much perturbated.

\section{Interval 3-1, $50 \mathrm{~cm}$ to the Base of the Hole}

This is a type III unit. It is an homogeneous sediment up to the contact with the basalt. Nevertheless, two intervals $(3-5,30 \mathrm{~cm}$ to $70 \mathrm{~cm}$ and $4-1,0 \mathrm{~cm}$ to $75 \mathrm{~cm})$ are characterized by the presence of fine, blackish granules visible to the naked eye. These units have characteristics intermediate between types I and II. Finally, black compact nodules, reaching up to $3 \mathrm{~cm}$ in diameter, have been observed at different levels $(3-1,105 \mathrm{~cm} ; 3-5,100$ $\mathrm{cm}$ to $105 \mathrm{~cm} ; 3-7,5 \mathrm{~cm}$ to $10 \mathrm{~cm}$, and $4-1,110 \mathrm{~cm}$ ), and fragments of nodules are often present inside the sedimentary column.

\section{Hole 424A}

Interval 1-1, $0 \mathrm{~cm}$ to $1-1,33 \mathrm{~cm}$

This is a type III unit, much disturbed, containing black fragments similar to those present in type I.
Interval 1-1, $33 \mathrm{~cm}$ to $123 \mathrm{~cm}$

This is a type I unit. Because of perturbation in the sedimentary column, the contact with the preceding unit is difficult to determine. This sediment contains numerous black granules of about $1 \mathrm{~cm}$.

Interval $1-1,123 \mathrm{~cm}$ to $1-2,18 \mathrm{~cm}$

This is a type III unit similar to the forementioned uppermost interval of Hole $424 \mathrm{~A}$.

Interval $1-2,18 \mathrm{~cm}$ to $36 \mathrm{~cm}$

This is a type II unit.

\section{Interval 1-2, $36 \mathrm{~cm}$ to the Base of Core 1}

This section is composed of several phases. Dark green or black granules, representative of type II, are dominant; some of these tend to be of a moderate olivebrown color $(5 \mathrm{Y} 4 / 4)$. In the upper part of this type II unit, fragments of black crusts are present. Thus, this part of the sampling is a mixture of dominant type II deposit and type III. Furthermore, it contains black granules.

Interval $2-1,0 \mathrm{~cm}$ to $120 \mathrm{~cm}$

This is a type III deposit of greenish gray (5 GY 6/1) color, containing black fragments whose size may reach $5 \mathrm{~cm}$.

Interval $2-1,120 \mathrm{~cm}$ to $2-2,80 \mathrm{~cm}$

This is a type II unit. The size of granules may reach 5 mm.

Interval $2-2,80 \mathrm{~cm}$ to $2-3,140 \mathrm{~cm}$

This is a type III unit. This section contains grayish green (10 G 4/2) nannofossil chalk fragments which may reach $2 \mathrm{~cm}$.

\section{Interval 2-3, $140 \mathrm{~cm}$ to $145 \mathrm{~cm}$}

This is a type II unit. The upper and the lower limit are very sharp, indicating conditions of deposit quite different from those of subjacent and overlying units.

Interval 2-3, $145 \mathrm{~cm}$ to the Base of the Hole (contact with the basalt)

This is a type III unit.

\section{Hole 424B}

\section{Interval 1-1, $0 \mathrm{~cm}$ to $1-2,70 \mathrm{~cm}$}

This is a type III unit with traces of bioturbation. Section $1-2,60 \mathrm{~cm}$ to $61 \mathrm{~cm}$ is distinguished by its white color.

\section{Interval 1-2, $70 \mathrm{~cm}$ to the Base of Core 1}

The sedimentary column is very disturbed. It is composed of irregular zones of light olive-brown (5 Y 5/6), dusky brown (5 YR 2/2), dark green or black color. It seems as if this unit should be linked; this is type II unit. 
The entire Core 2 is a type II unit. Its upper part has a moderate olive brown color (5 Y 4/4) and tends progressively to a greenish black color ( $5 \mathrm{G} 2 / 1)$.

Core 3 presents an alternating sequence of type II and type III units. Limits are always sharp. Units of type II are: Intervals $3-1,0 \mathrm{~cm}$ to $3-2,28 \mathrm{~cm}, 3-2,45 \mathrm{~cm}$ to $3-3,30 \mathrm{~cm}, 3-3,60 \mathrm{~cm}$ to $80 \mathrm{~cm}, 3-3,147 \mathrm{~cm}$ to $3-4,70$ $\mathrm{cm}, 3-4,123 \mathrm{~cm}$ to $132 \mathrm{~cm}, 3-5,128 \mathrm{~cm}$ to $140 \mathrm{~cm}$.

Core 4 is a type III unit. In the interval $4-1,0 \mathrm{~cm}$ to $75 \mathrm{~cm}$, black nodules (up to $3 \mathrm{~cm}$ ) are present.

\section{Hole 424C}

This hole, which has been only partially sampled, is composed of one type of sediment, which is fine and homogeneous. Its color varies from dusky yellow-green (5 GY 5/2), to moderate olive-brown (5 Y 4/4), to pale olive $(10 \mathrm{Y} 6 / 2)$. Only the first $12 \mathrm{~cm}$ has a dusky yellow brown color (10 YR 2/2), probably due to oxidation phenomena which occur at the water/sediment interface.

This type of sediment is similar to type III. Because of some gaps in the recovered sedimentary column, we do not know if type II or III is present in this hole. Nevertheless, if present it is not in the upper part of the hole as was the case in the three preceding holes.

\section{Location and Importance of the Three Types of Deposits}

Type I, in Holes 424 and $424 \mathrm{~A}$, is always present in the upper part of these holes. In Hole 424 it is on the surface, which could connect it with the black material observed in the deep-sea photographs in this zone (Corliss et al., 1978). In Hole $424 \mathrm{~A}$ it is separated from the water/sediment interface by a thin layer of type III sediment. The type I deposits are less numerous.

Type II seems to have two slightly divergent locations. It can be found in the upper part of the holes (either directly under type I deposits, or under a type III deposit), as well as in the middle part of the holes. In the latter case, it is always between type III deposits; the borders between the different units are generally quite clear.

Type III is always present in the lower part of the holes, over the basalt. It is also connected in the upper part of the holes with Type II deposits. Finally, in Holes $424 \mathrm{~A}$ and $424 \mathrm{~B}$ it constitutes a thin, superficial layer overlaying type I or type II.

\section{Relationships Between the Three Types of Deposits}

The contacts between the different types of deposits are generally not easy to establish because of the disturbances of the sedimentary column by the drilling. Nevertheless, intermediate types between types I and II seem to be present (Hole 424), and clear demarcations between types II and III on the one hand, and I and III on the other hand, can be easily seen (e.g., Interval $424 \mathrm{~A}-2-3,140 \mathrm{~cm}$ to $145 \mathrm{~cm}$ ).

It thus seems that there is a link between types I and II and no connection between those two types and type III.
In the following section, the results of smear slide and thin section observations will be set out.

\section{Hole 424}

Core 1 , which appears to be a type I unit, is characterized by two dominant phases:

1) Granules with sharp edges (up to $1 \mathrm{~mm}$ ) that are essentially green-brownish. They are prevalent in most samples. The aspect and the morphology of these granules are analogous to those of the granules represented in Figure 2.

2) Oxyhydroxides, almost isotropic under crossed nicols and comprised of black amorphous blots.

With the exception of these two phases, scarce fragments of foraminifers, coccoliths, and sponge spicules are present. A few quartz grains can be detected.

\section{Interval 2-1, $0 \mathrm{~cm}$ to $2-3,133 \mathrm{~cm}$ (Type II Unit)}

The dominant phase consists of sharp-edged granules, whose morphology is similar to those of Core 1 but whose color is bright or dark green. Only a few oxyhydroxides are present. The aspect of this sediment can be seen in Figure 2 (photographs 3 and 4). No organisms have been observed. Very few quartz grains have been discovered. One of the particularities of this level is the existence of scarce automorph calcite crystals.

\section{Interval $2-2,133 \mathrm{~cm}$ to $\mathbf{2 - 4}, 25 \mathrm{~cm}$ (Type III Unit)}

This is a foraminifer-nannofossil ooze containing scarce fragments of often altered siliceous organisms and of scarce white, colorless volcanic glass. The argilaceous phase is reduced. Some greenish granules are detectable.

\section{Interval $2-4,25 \mathrm{~cm}$ to $110 \mathrm{~cm}$}

Sediments are of type II. However, some trace of calcareous organisms are present.

\section{Interval 2-4, $110 \mathrm{~cm}$ to the Base of the Core}

This section appears disturbed to the naked eye. The composition of the sediments undergoes abrupt changes along the core, and it is possible that mixtures of different types of sediments occur. However, the bulk is composed of a foraminifer-nannofossil ooze.

\section{Interval 3-1, $0 \mathrm{~cm}$ to $50 \mathrm{~cm}$}

For the greater part, this section is composed of sharp-edged granules. They are green-brownish near the core surface and drift toward a dark green shade near Section $3-1,50 \mathrm{~cm}$. Moreover, near the surface black oxyhydroxides make up from 20 to 30 per cent and disappear near the base. Therefore, it seems there might be a zonation within this $50-\mathrm{cm}$ interval.

\section{Interval 3-1, $50 \mathrm{~cm}$ to the Base of the Hole}

This is a foraminifer-nannofossil ooze containing fragments of siliceous organisms and scarce, white colorless volcanic glass. Very few discoasters have been detected, perhaps indicating the presence of bottom currents. Intervals $3-5,30 \mathrm{~cm}$ to $70 \mathrm{~cm}$ and $4-1,0 \mathrm{~cm}$ to 75 $\mathrm{cm}$ are differentiated from each other by the presence of dark green, sharp-edged granules. 

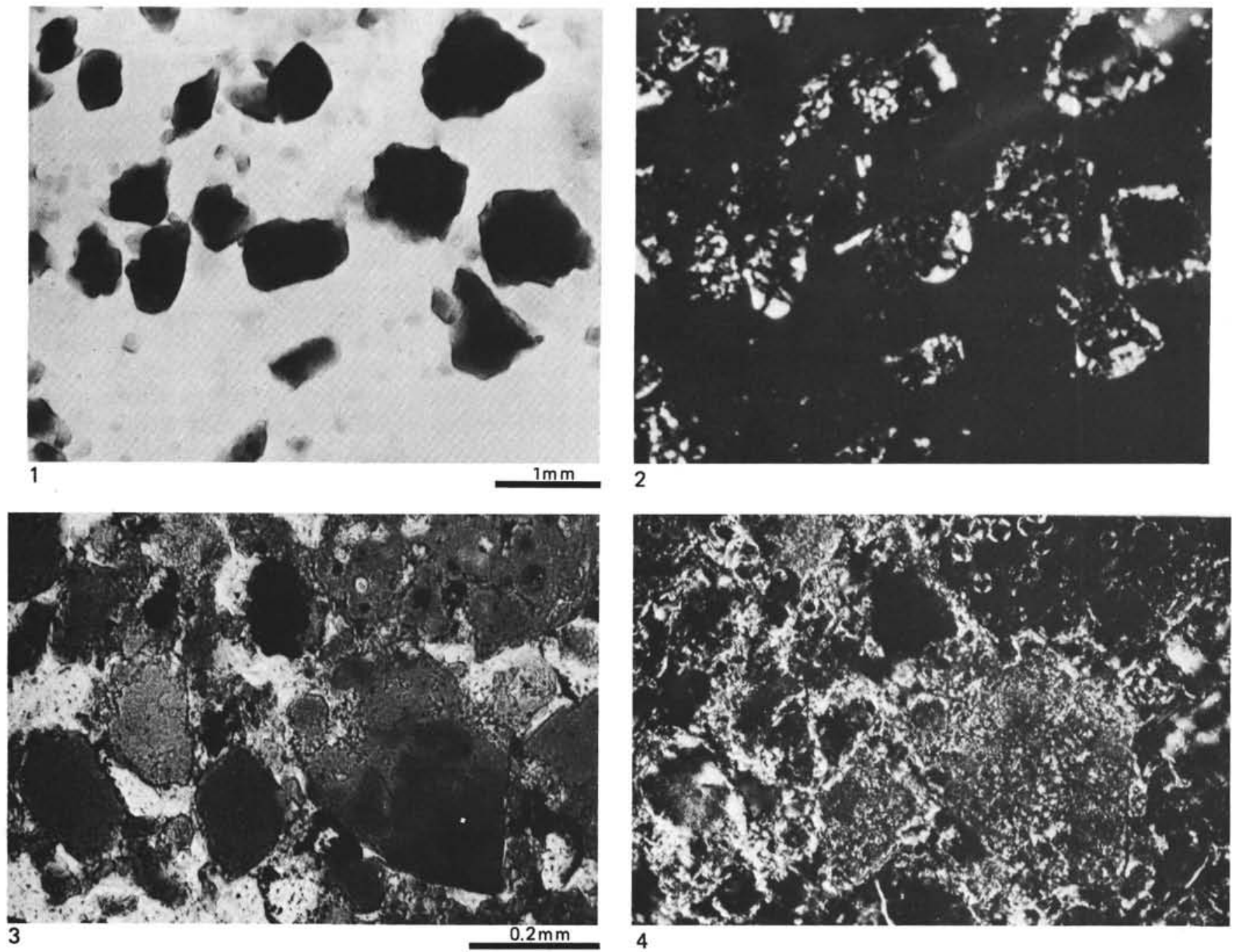

Figure 2. Aspects of hydrothermal deposits in smear slides and in thin sections. (1) Sample 424A-2-3, 142-144 cm (ordinary light). Green granules are about $1 \mathrm{~mm}$ in size, smear slide. (2) Same sample (crossed nicols). (3) Thin section in Sample 424-2-1, 56-58 cm. Granules have very sharp edges. Scarce oxyhydroxides are present. (4) Same sample (crossed nicols).

\section{Hole 424A}

\section{Interval 1-1, $0 \mathrm{~cm}$ to $33 \mathrm{~cm}$}

This is a foraminifer-nannofossil ooze, containing scarce, dark green granules.

\section{Interval 1-1, $33 \mathrm{~cm}$ to the Base of Core 1}

Resulting from the considerable disturbance of the core, strong variations appear in the composition of the sediment in smear slides when taken from neighboring levels. Yet the main phase of this section is composed of blackish or brownish red patches and granules that are identical to those of type II and whose colors vary from green to brown. The proportion of calcareous organisms varies greatly. Scarce fragments of siliceous organisms, of quartz grains, and of volcanic glass have been detected. The sediment appears therefore as a mixture of types I and II already described. This mixture is probably a result of the coring.
Interval $2-1,0 \mathrm{~cm}$ to $120 \mathrm{~cm}$

This is a foraminifer-nannofossil ooze containing scarce, green granules and scarce oxyhydroxides.

Interval $2-1,120 \mathrm{~cm}$ to $2-2,80 \mathrm{~cm}$

The sediment is composed of dark green, sharpedged granules. Thus, this unit is of type II. However, scarce calcareous organisms can be observed, increasing toward the base.

\section{Interval $2-2,80 \mathrm{~cm}$ to $2-3,140 \mathrm{~cm}$}

This is a foraminifer-nannofossil ooze containing scarce green granules.

\section{Interval 2-3, $140 \mathrm{~cm}$ to $145 \mathrm{~cm}$}

This unit, having sharp limits, is mostly constituted of green granules. Traces of calcareous organisms are present. It is a type II unit. Figure 2 shows the aspect of this type of deposit. 
Interval 2-3, $145 \mathrm{~cm}$ to the Base of the Hole

This is a foraminifer-nannofossil ooze containing scarce green granules.

\section{Conclusion}

The same facies as in Hole 424 can be found, but in another disposition and always associated in varying proportions.

\section{Hole 424B}

Interval 1-1, $0 \mathrm{~cm}$ to $1-2,70 \mathrm{~cm}$

This is a foraminifer-nannofossil ooze. Section 1-2, $60 \mathrm{~cm}$ is made up of blots of pure siliceous white glass ( $n$ $=1.50$ ). Very scarce hydroxides are detectable as well as scarce dark green granules.

\section{Interval 1-2, $70 \mathrm{~cm}$ to the Base of Core 1}

The sediment is composed of bright brown and greenish, sharp-edged granules. Oxyhydroxides are scarce, and so are siliceous and calcareous organisms. This type of sediment resembles type I described before but differs from it by its low quantity of oxyhydroxides.

Core 2 is composed only of green granules. Oxyhydroxides are very scarce. A few crystals of calcite are detectable. This core belongs therefore to type II.

Apart from what has already been learned from visual observation, we note that in the upper part of Core 3 (Sample 3-1, 30-32 cm) the color of the granules is rather brownish and their shape is blurred. The granules tend toward a dark green color. It appears there exists a color zonation in the granules: the greener the color is, the fresher the granules seem. On the other hand, when the color tends toward brown, the edges tend to be less splintery and more blurred.

Core 4 completely corresponds to a foraminifer-nannofossil ooze.

\section{Conclusion}

The same units as before can be found, but type II prevails over type I, which is almost entirely missing.

\section{Hole 424C}

This is a sediment composed in its uppermost part of a foraminifer-nannofossil ooze and in its bottom part (starting with Section 2) of a siliceous nannofossil ooze. Granules are very scarce. Only Sample 1-3, 59-61 cm contains about 5 per cent granules with a green-brownish color and blurred edges. The surface level contains very few traces of oxyhydroxides. The larger number and the better preservation of siliceous organisms differentiate this type (III) from the sediments of Holes $424,424 \mathrm{~A}$, and 424B. It appears therefore that the environment of type I and II sediments does not seem favorable for the preservation of siliceous organisms.

\section{MINERALOGICAL STUDIES}

\section{Bulk Sediment}

$\mathrm{X}$-ray diffraction photographs were made for most of the samples on amorphous powders. Confirmation of the forementioned three types of sediments was obtained. Figure 3 shows the three types of diffraction charts.

\section{Type I}

The clay minerals appear as the major constituent. They are characterized by a basal reflection between 9.5 and $12 \AA$ as well as peaks at $4.5,2.5$, and $1.51 \AA$. The precise determination of these clay minerals will be made by oriented X-ray diffractograms. The presence of a peak near $12 \AA$, one at about $3.2 \AA$, as well as the position of the other peaks favor the smectitic nature of these clay minerals.

Other reflections resemble elevations rather than peaks. First, there is an elevation situated near $3.6 \mathrm{~A}$, which should correspond to amorphous silica (Trichet, 1970). Since the smear slides have shown the almost complete absence of siliceous organisms and of volcanic glass, this elevation must be indicative of a siliceous amorphous phase of unknown origin. A small peak at $4.19 \AA$ corresponds to goethite. Yet, this peak is on an elevation near $4.2 \mathrm{~A}$, which indicates the presence of Feoxyhydroxides. Lastly, a peak near $2.4 \AA$, could signify badly crystallized Mn. We shall see that in type I sediments, in which black fragments are abundant, wellcrystallized $\mathrm{Mn}$ oxides are also present.

\section{Type II}

This type of diagram shows great similarity with that of type I: abundant clay minerals, the presence of FeMn oxyhydroxides, as well as of amorphous silica. Only the presence of halite and the absence of goethite distinguish this type from type I.

\section{Type III}

This is characterized by the predominance of calcite (derived from organisms), by the small proportion of clay minerals, the greater abundance of halite, and also by traces of plagioclase.

So it appears that types I and II very nearly constitute mineralogical phases. To confirm this, a mineralogical analysis is in order.

\section{Dark Green and Brown Granules}

This study has been made using a scanning electron microscope on bulk sediments of Type II as well as on isolated granules after washing the sediment with water. (Figure 4 shows the main morphological types). The results show that the granules are composed of particles of fibrous structure, whose size is about $10 \mathrm{~mm}$ and whose aspect is globular. The aspect of the granules is very similar in all the holes, yet in a single hole the coherence of the granules may vary. The aspect of these granules is also very similar to that of glauconite grains described by Odin (1975). 


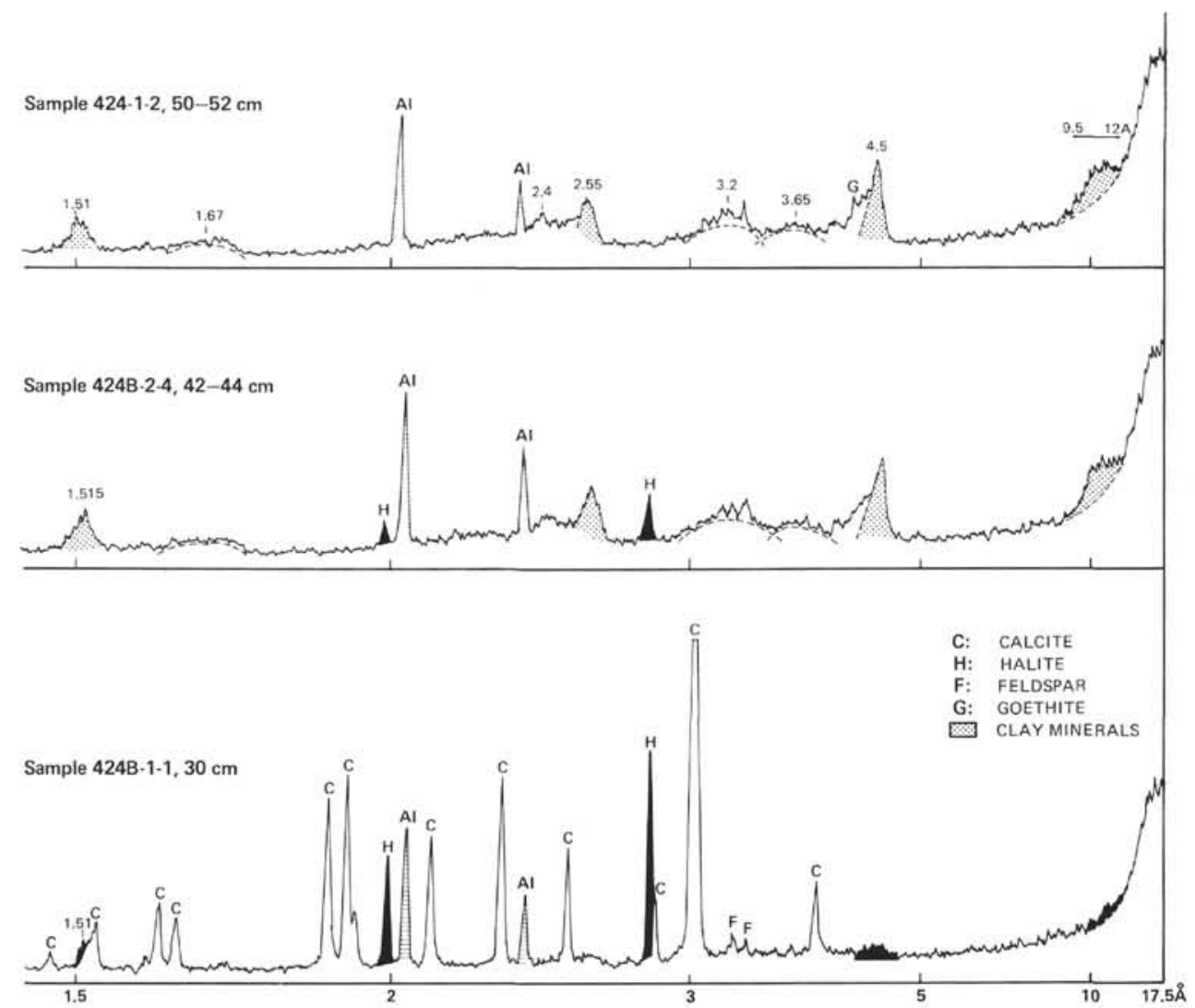

Figure 3. X-ray diffraction charts of the principal three types of deposits. Al-peaks correspond to the powder holders.

\section{X-Ray Diffraction of Isolated Granules}

This study has been made by isolating granules and selecting them according to their green or brown color. Two examples of X-ray diffraction charts are shown in Figure 5. The general aspect of an X-ray diffraction chart on an isolated granule is similar to that of type I and II bulk sediment. The reflections are those of a smectite. However, it can be seen that the position of the principal peak varies according to the color of granules. For green (e.g., Sample 424B-2-3, 20-22 cm), the principal peak is near $11 \mathrm{~A}$. On the other hand, for brown (e.g., Sample 424-1-2, 17-19 cm), the peak is nearer to $12.5 \mathrm{~A}$. It seems therefore that a relationship exists between the color and the mineralogical nature of the granule. It must be noted that the aspect of the X-ray diffractogram, with a peak near $11 \AA$, is similar to that of glauconite presented by Odin (1975).

\section{Clay Mineral Study (on $<2-\mu \mathrm{m}$ fraction)}

The clay fraction has been studied by X-ray diffraction on three types of orientated aggregates: untreated clays, clays treated with ethylene glycol, and clays heated at $490^{\circ} \mathrm{C}$ for 2 hours. Lastly, Mg-saturation has been effected on the three types of aggregates. Two examples of such X-ray diffraction charts are shown in Figure 6. We can see that these minerals are characterized by a basic peak between 11.5 and $12.5 \AA$, but that after $\mathrm{Mg}$-saturation, this peak has shifted to near $14 \mathrm{~A}$.
After treatment with ethylene glycol, the principal peak moves toward $17 \AA$. These minerals are therefore smectites. However, another peak near $10 \AA$ indicates that a second clay mineral must be present. This type of diagram is essentially the same in all the type I and II deposits; only the intensity of the peak near $10 \AA$ varies.

A specimen of a brown granule (Sample 424-1-2, $17-19 \mathrm{~cm}$ ), which appears almost exclusively composed of smectites, has been studied by scanning electron microscopy in order to determine its morphology (Figure 7). The granules have highly irregular surfaces and the smectites look like agglomerates of small elongated glomerules (like "brains"). This is a characteristic morphology of neoformation (Person, 1976).

SEM observations and microdiffraction (Phillips EM300) results on isolated particles are shown in Figures 8,9 and 10. The main conclusions are as follows:

The dominant clay mineral occurs as lath-like material of very small size.

A second type of clay mineral appears as "ringlets."

The lath-minerals seem to grow in a radial manner, starting from other particles and particularly from "ringlet-type" minerals.

Illite or chlorite minerals are extremely scarce, and laths also seem to grow from them.

The microdiffraction study shows that these lathminerals are smectites with a 060 reflection near $1.51 \AA$. 

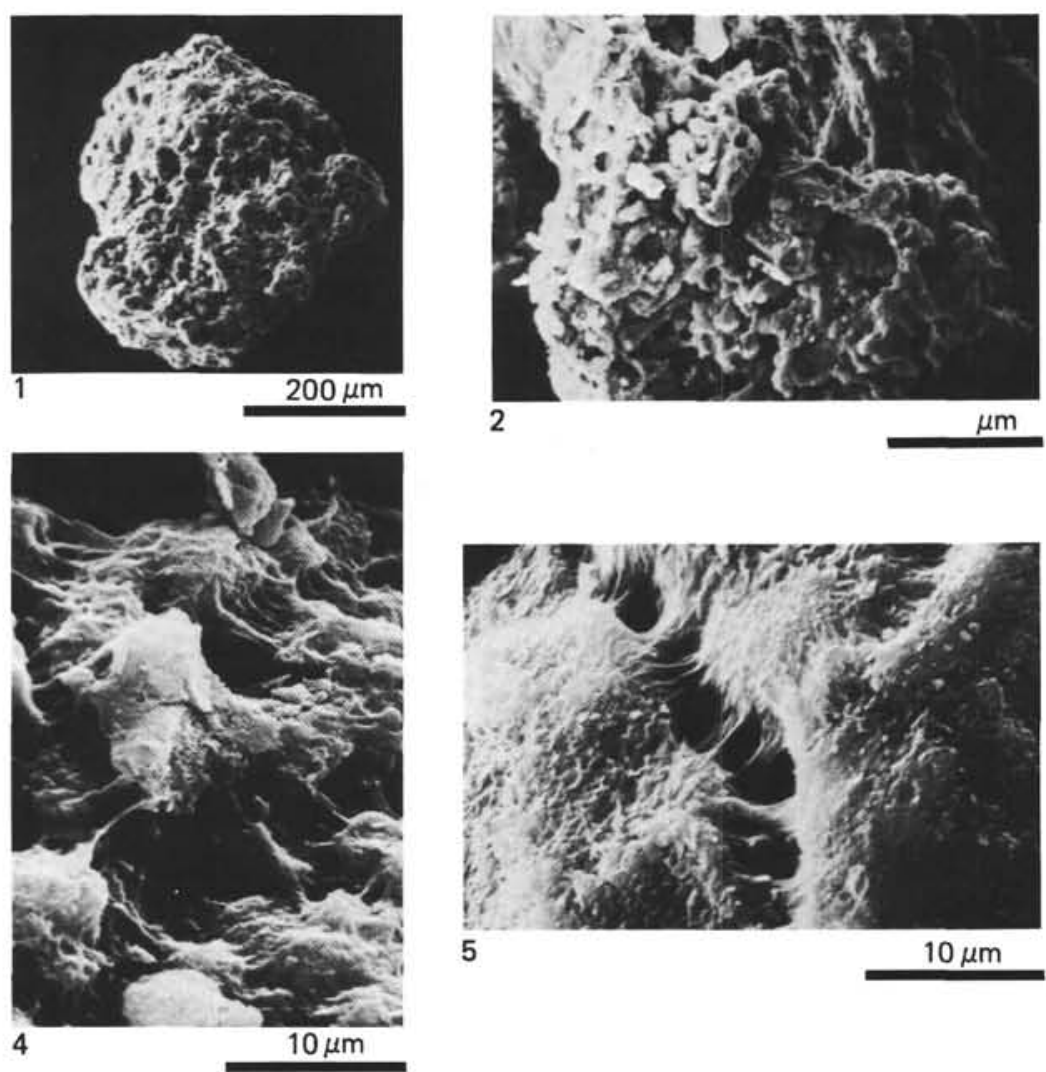

5

$10 \mu \mathrm{m}$

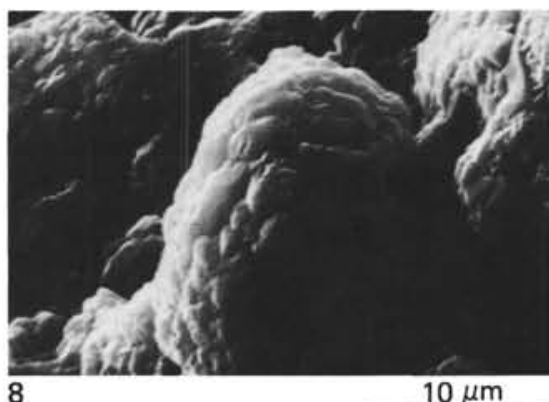

$10 \mu \mathrm{m}$

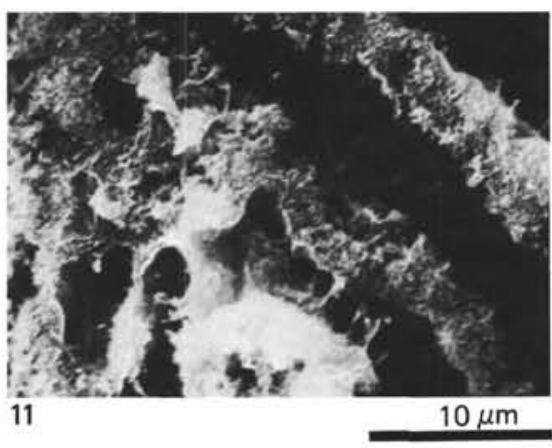

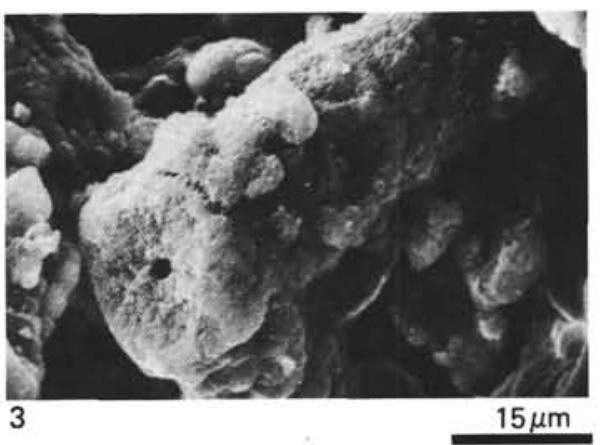

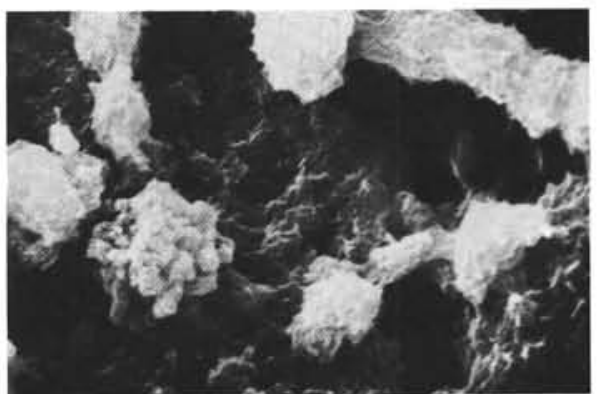

6

$10 \mu \mathrm{m}$

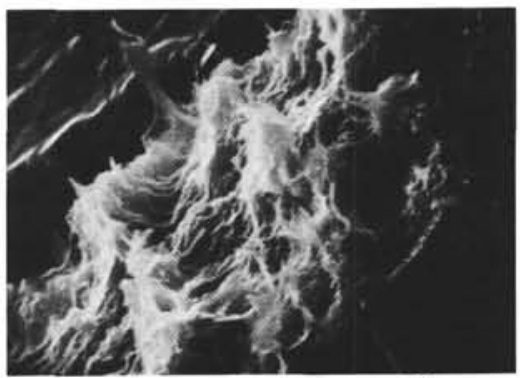

9

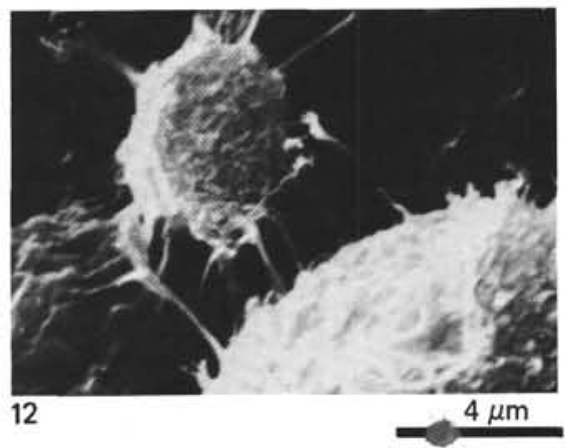

Figure 4. Morphology of dark green or brown granules in SEM examination. (1) Sample 421-1, 90-92 cm: green granule isolated after washing with water. (2) Same sample: it appears that the granule itself is composed of smaller units, whose size is about $10 \mu \mathrm{m}$. (3) Same sample: detail of one of the component units making up the granules. Here the structure is elongated and it seems that a hollow channel is in its center. (4 and 5) Same sample: fibrous structures which link the units described above. (6) Same sample: detail of a sub-unit of the granules. They seem themselves to be composed of an agglomerate of particles whose size is near $1 \mathrm{vm}$. (7) Sample 424A-2-2, 9-11 cm: aspect of the surface of a green granule. Note the presence of sub-units whose size is about 10 $\mu m$. (8) Same sample: detail of granular sub-unit. (9) Same sample: fibrous aspect often presented by the surface of the granules. (10) Sample 424B-3-4, 63-65 cm: fibrous structures on the surface of green granules. (11 and 12) Same sample: detail of its fibrous structure. 


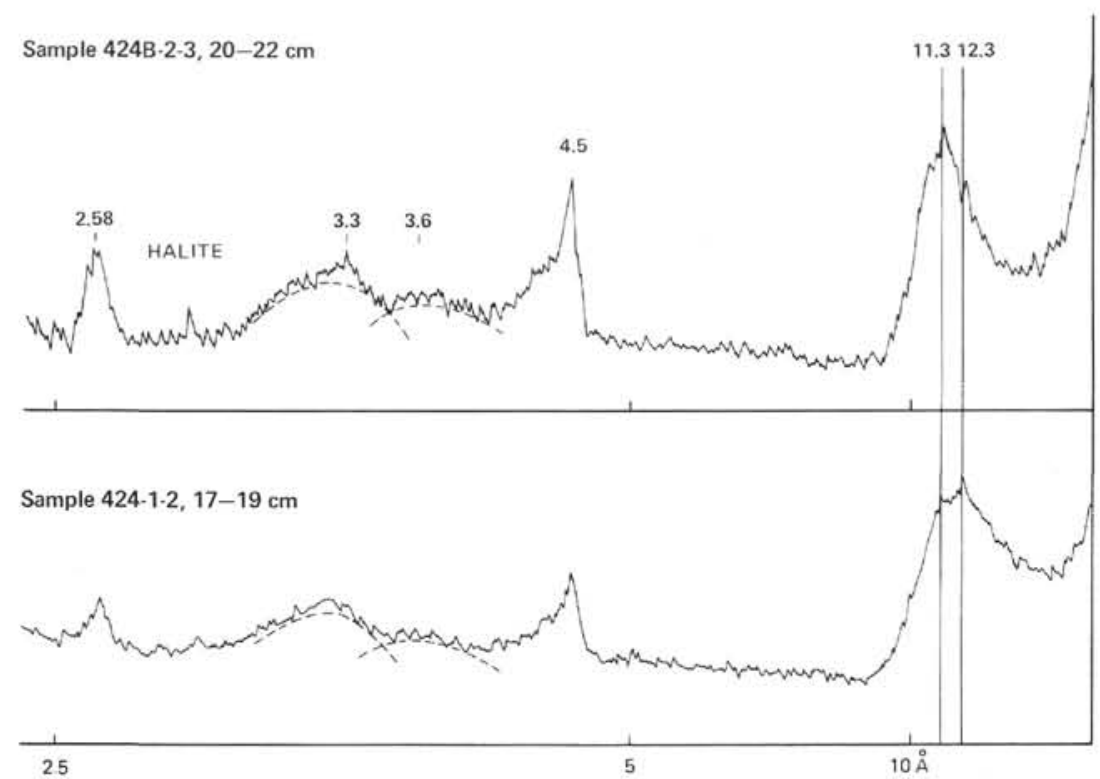

Figure 5. X-ray diffraction charts of isolated brown and green granules. Sample 424B-2-3, 20-22 cm: green granule; Sample 424-1-2. 17-19 cm: brown granule.

The geochemical study permits us to determine their composition accurately.

\section{Manganese Oxides}

The main results are shown in Figures 11, 12, and 13. The manganese minerals present two principal aspects:

As slabs (up to $1 \mathrm{~cm}$ ) of dark gray color. These are either a homogeneous mass or a mass surrounding a core composed of smectitic granules (e.g., Sample 424 $\mathrm{A}-1, \mathrm{CC})$.

As concretions. These are composed of a black crust with metallic lustre covering argillaceous structures, as well as non-mineral structures (e.g., Samples 424-1-2, 17-19 $\mathrm{cm}$ and 424-3-1, 5-7 cm).

The Mn oxides form later than the smectitic granules - at the water/sediment interface - as proved by the presence of organic remains in an environment suitable for the preservation of organic matter.

The agglomerated blades structure is identical to that of the todorokite described by Strazeck et al. (1960) and springs from an environment where the growing of $\mathrm{Mn}$ is facilitated. In the concretions, blades of Mn are flatter; they are organized into globular structures that are perpendicular to the center of the support. This structure is identical to that of Mn oxides observed in the FAMOUS hydrothermal deposits (Person, 1976; Hoffert et al., 1978).

After light crushing without raising the temperature, a microsample was subjected to diffractometric analysis on a revolving-sample support. Two examples of X-ray diffraction charts are presented in Figure 14. We note that $\mathrm{Mn}$ is present, as well-crystallized todorokite.
Peaks for this todorokite are similar to those presented by Burns (in Glasby, 1978).

\section{Todorokite Under Different Thermal Conditions}

Homogeneous powders were prepared for analysis on a Mn slab (Sample 424-1, CC). X-ray diffraction diagrams were made for each of two preparations after heating the samples in increments of $100^{\circ} \mathrm{C}$ during 5 hours and cooling over a 24 -hour period. The first diffraction diagram was made on one sample at $25^{\circ} \mathrm{C}$, for the other at $54^{\circ} \mathrm{C}$. An example of such a series of X-ray diffraction charts is given in Figure 15.

The peak of the todorokite shifts from $9.8 \AA$ to 9.22 $\AA$. This seems to correspond to a loss of water in the structure or to a modification of the hydrogen bonds. Thus the position of the principal peak of todorokite can be plotted versus temperature (Figure 16). Finally, toward $600^{\circ} \mathrm{C}$ the diagram of the haussmanite $\mathrm{MnO}$, $\mathrm{Mn}_{2} \mathrm{O}_{3}$ (ref. A.S.T.M. No. 24 734) appears. In this diagram, a modification of plane (103) occurs, which results from the presence of iron in the initial product.

To compare this Mn oxide with another type of Mn deposit, the analyses were repeated on a polymetallic nodule from the North Pacific. We found that the todorokite from the DSDP holes is more thermally resistant (up to $300^{\circ} \mathrm{C}$ ) than the todorokite from the nodules, which is destroyed at about $160^{\circ} \mathrm{C}$. Moreover, the contraction of the peak at $9.8 \AA$ occurs more quickly in the nodules, which means that the latter's organization is more fragile.

To conclude, the todorokite from this hydrothermal environment seems characterized by a better crystalline organization than todorokite of hydrogenous deposits such as nodules. 

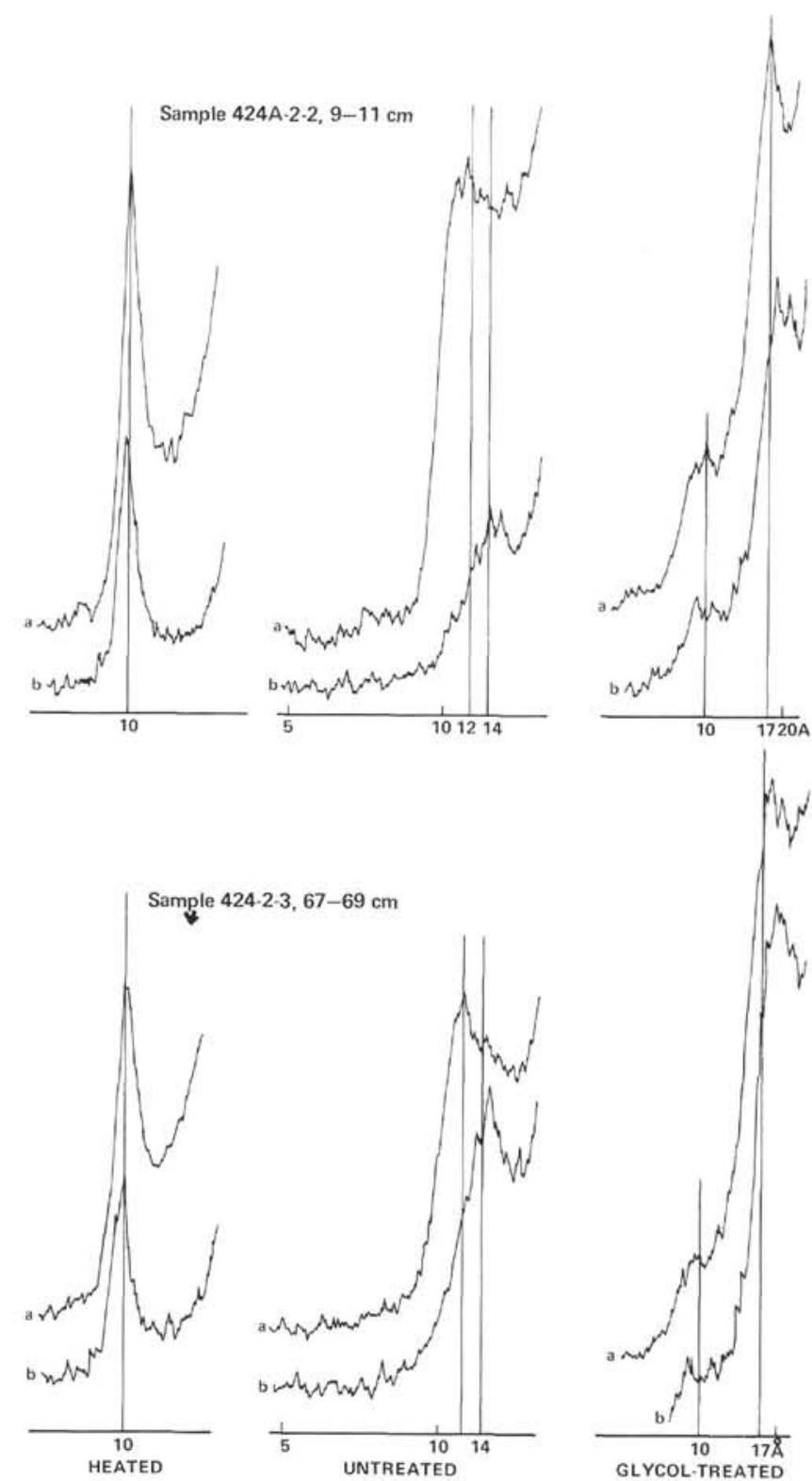

Figure 6. X-ray diffraction charts of the clay fraction
of hydrothermal deposits. (a) Non-saturated sample; (b) Mg-saturated sample.

\section{Clay Minerals in the Foraminifer-Nannofossil Ooze}

To compare the clay minerals from the granules with those present in the foraminifer-nannofossil ooze, $\mathrm{X}$-ray diffraction studies have been made on the $<2-\mu \mathrm{m}$ fraction from type III sediments. Two examples of such $\mathrm{X}$-ray diffraction charts are given in Figure 17, from which we can conclude that these minerals are of the smectitic type. Their basic peak is near $15 \AA$. Electron microscope observation reveals that the aspect of these minerals appears as folded flakes with blurred shape (Figure 18). Thus, the nature of the clay minerals of types I and II is different from that of type III minerals. However, the latter in turn are different from those of a typical deposit from the Panama Basin (Hoffert, manu- script in preparation; Heath et al., 1974). We can combine this fact with the observation made in Figure 9, where we see lath-minerals growing radially on an illite or chlorite mineral. This seems to indicate that the clay minerals that are not of hydrothermal origin are unstable in this environment and tend to transform themselves into a more stable clay structure.

\section{GEOCHEMICAL STUDIES}

\section{Major Oxides and Trace Elements}

\section{Laboratory Methods}

Chemical analyses by arc spectrometry, using an ARL quantometer, were made after the method described by Besnus and Rouault (1973) and Besnus and Lucas (1968). This consists of melting the sample in a mixture of lithium tetraborate and introducing the melt into a glycolated solvent. Trace elements were determined using graphite dishes as described by Besnus and Lucas (1968). Na and $\mathrm{K}$ were determined by emission spectrometry. Relative precision is \pm 2 per cent for major oxides, \pm 20 per cent for trace elements.

\section{Major Oxides}

The results are presented in Tables 1, 3, 5, 7, 9, 10, 11 , and 12 . All these analyses have been recalculated on a calcium-free basis (Tables 2, 4, 6, and 8; Figures 19 through 23).

\section{$S i-A l$}

$\mathrm{Si}$ is the dominant element in type I and II sediments which contain very small amounts of Al. The ratio of $\mathrm{Si} / \mathrm{Al}$ is therefore very high and this is a characteristic of both type I and II deposits. These deposits appear very similar to those of the FAMOUS hydrothermal deposits (Hoffert et al., 1978). The ratio $\mathrm{Si} / \mathrm{Al}$ also serves to make a distinction within type I and II deposits, being highest in the upper part of the holes, on levels which are not interbedded with carbonate oozes. In type III deposits, $\mathrm{Si} / \mathrm{Al}$ has a low value, close to those for normal pelagic clay $(\mathrm{Si} / \mathrm{Al} \approx 4)$ (Tables $13-16)$.

Values of $\mathrm{Si}$ on a calcium-free basis are constant along the holes. Thus, $\mathrm{Si}$ and $\mathrm{Ca}$ are in competition in type III deposits where the content of $\mathrm{CaO}$ is high. In fact, in carbonate oozes, Ca "dilutes" Si. We can see on a $\mathrm{Ca}=0$ basis, that $\mathrm{Al}$ in type III deposits is of different origin than $\mathrm{Si}$ in types I and II. This indicates that in the studied deposits, $\mathrm{Si}$ is present in two distinct phases:

Types I and II: Si and $\mathrm{Al}$ are independent.

Type III: $\mathrm{Si}$ and $\mathrm{Al}$ are correlated.

\section{$\mathrm{Fe}$}

This element seems to be in close relationship with $\mathrm{Si}$ in type I and II deposits. The high $\mathrm{Si}-\mathrm{Fe}$ content is another characteristic of these deposits. However, in type III deposits $\mathrm{Fe}$ has the same variations as $\mathrm{Si}$. This indicates that the $\mathrm{Si}-\mathrm{Al}$ phase is also characterized by $\mathrm{Fe}$ in type III deposits. We thus find that:

Type I and II are $\mathrm{Si}-\mathrm{Fe}$

Type III is $\mathrm{Si}-\mathrm{Al}-(\mathrm{Fe})$ 

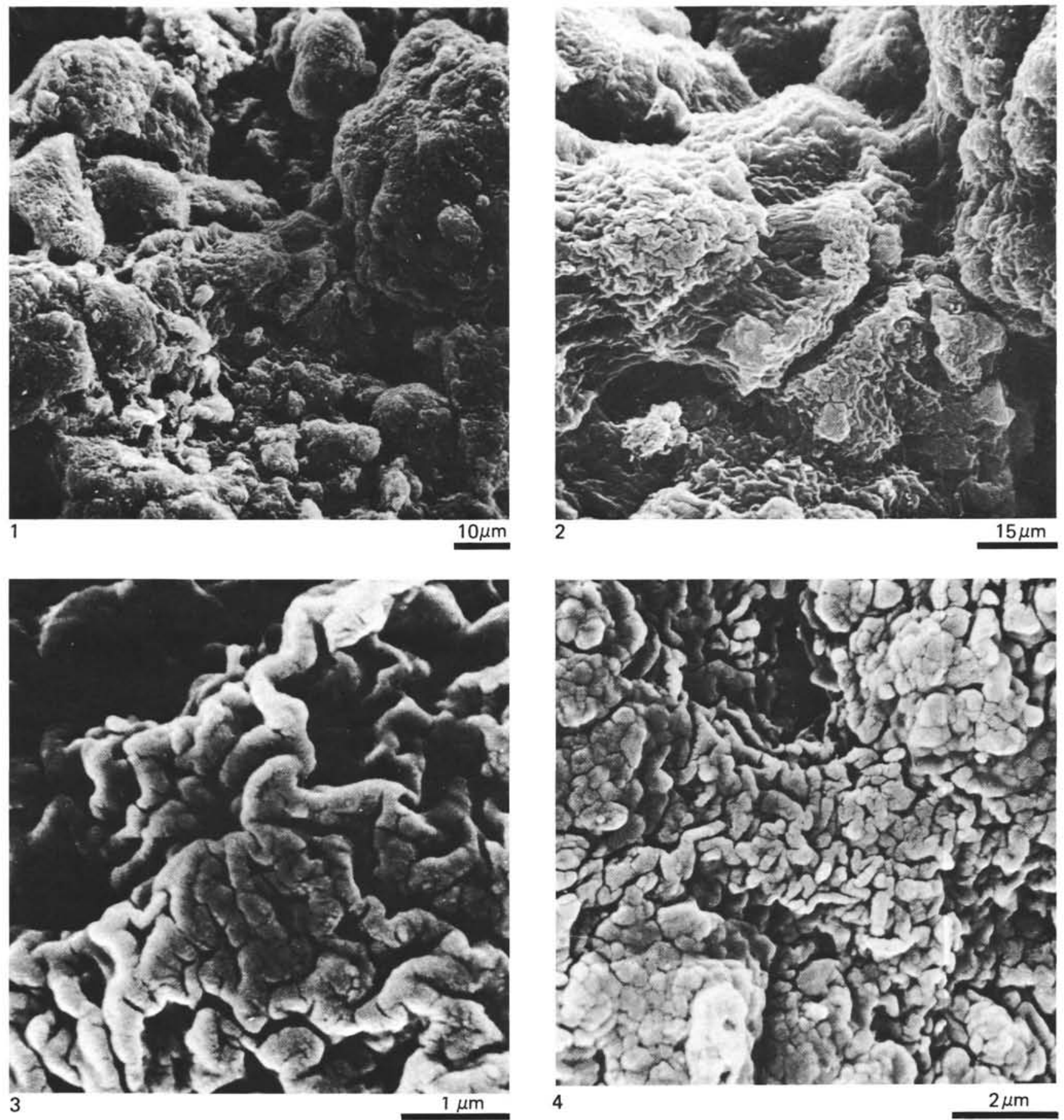

Figure 7. Morphology of a brown smectitic granule in SEM examination (Sample 424-1-2, 17-19 cm). (1) General aspect. (2) Detail of the constituent grains (up to $10 \mu \mathrm{m})$. (3-4) Detail of constituent grains: free-growing smectites.

$\mathrm{Mn}$

Manganese values are strong only in type I deposits. This indicates the independence of phases $\mathrm{Si}-\mathrm{Fe}$ and $\mathrm{Si}-$ $\mathrm{Al}-(\mathrm{Fe})$ from $\mathrm{Mn}$. An increase in $\mathrm{Mn}$ can be noted toward the base of the holes (perhaps because of proximity of the basalt).

\section{$\mathrm{Na}, \mathrm{K}$, and $\mathrm{Mg}$}

These elements have the same variations as $\mathrm{Si}-\mathrm{Fe}$, but nevertheless they serve to differentiate types I and II from type III. The highest $\mathrm{Na}$ values are in type I and II sediments. $\mathrm{K}$ is present in small quantities in type $\mathrm{I}$, and is associated preferentially, in type I and II, with $\mathrm{Si}-\mathrm{Fe}$. 

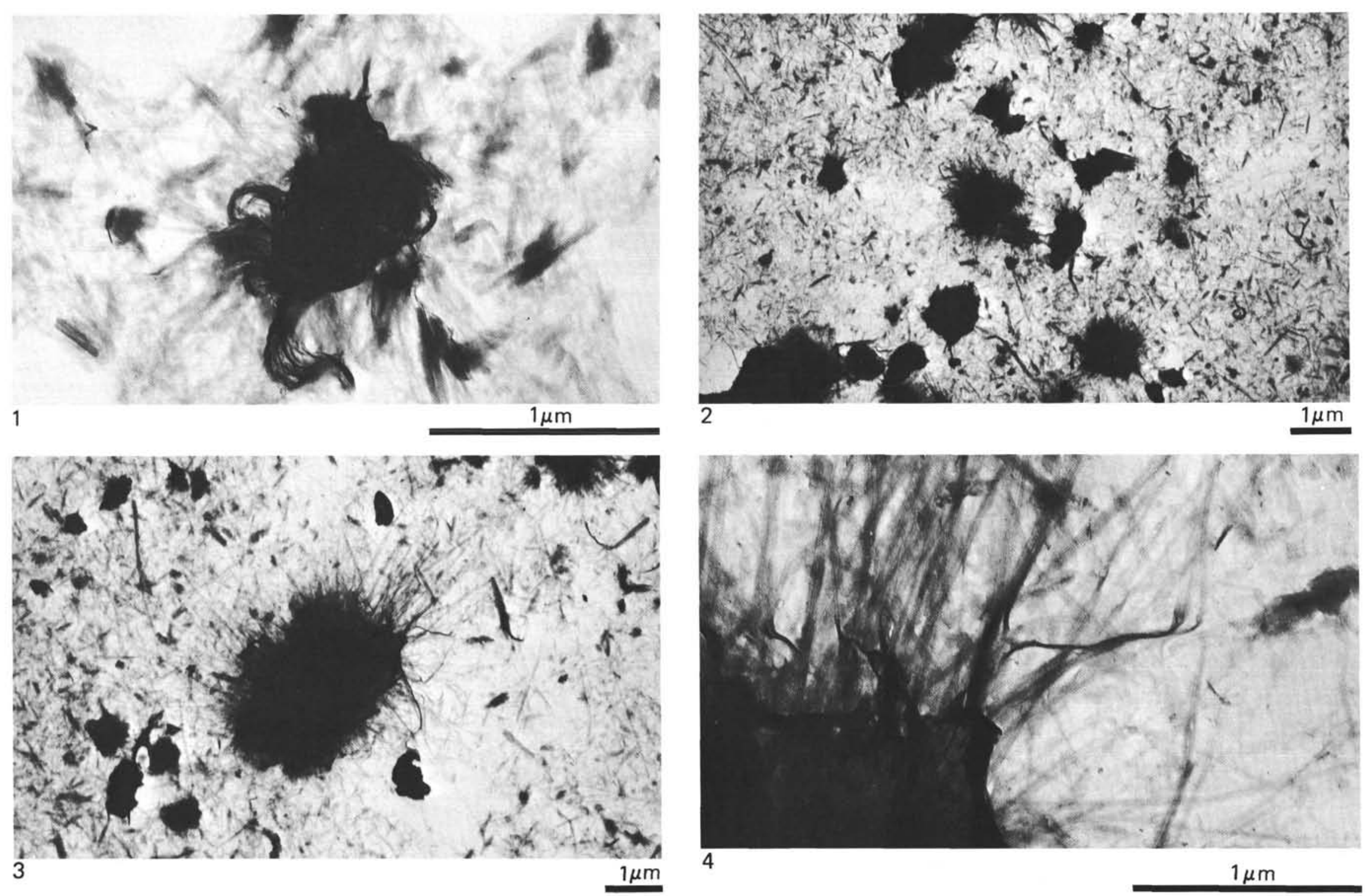

Figure 8. Electron microscope examination of Hole 424 sediments. (1) Sample 424-1-1, 89-91 cm: mineral with "ringlet" aspect and lath-like minerals. (2) Sample 424-3-1, 42-44 cm: general aspect. Two phases are present: abundant lath-like minerals and black particles, sometimes with "'ringlet-aspect" particle and at the expense of which fibers grow in radially. (3) Same sample: detail of the radial growth of fibers at the expense of an indeterminate particle of larger size. (4) Same sample: detail of such radial growth. 

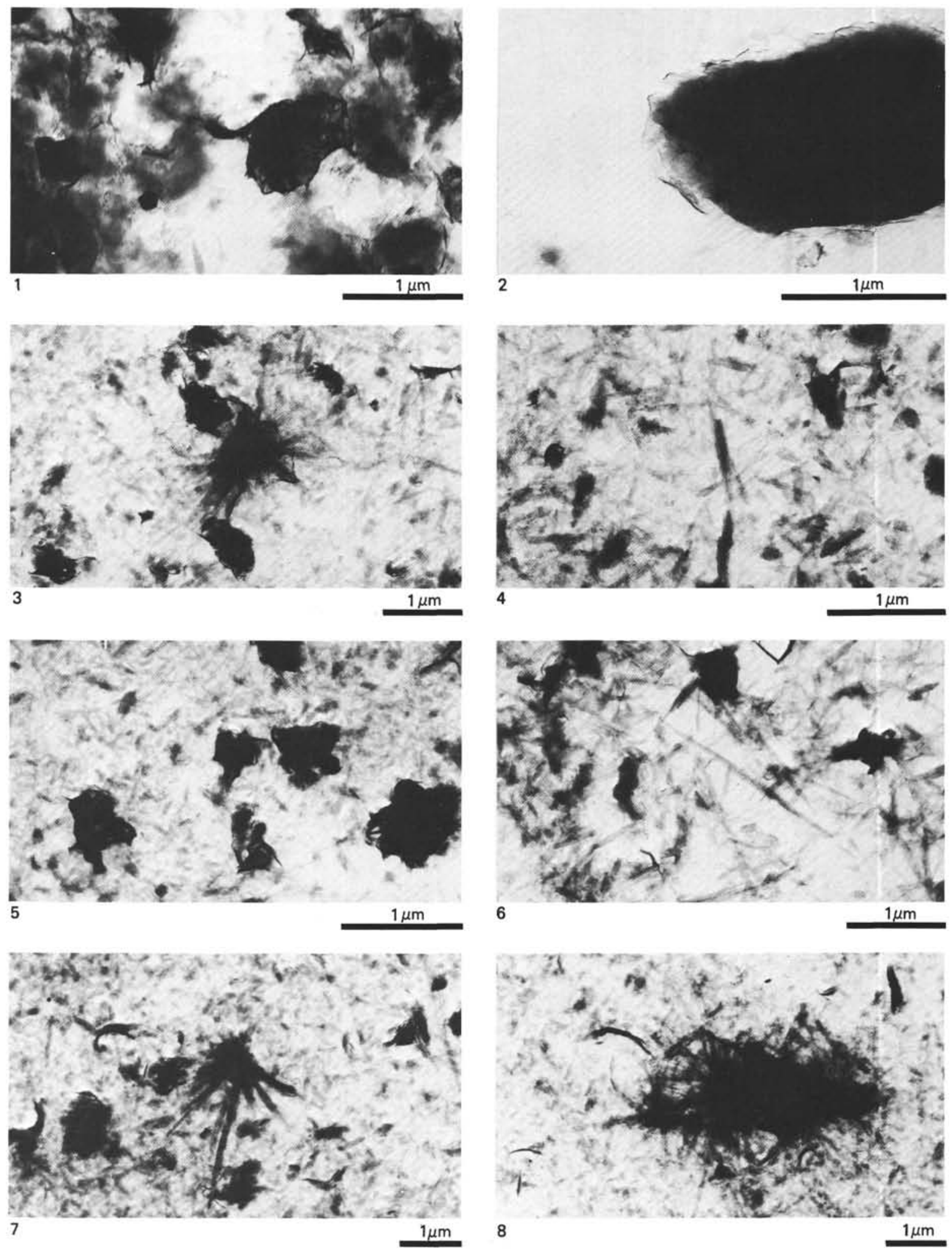

Figure 9. Electron microscope examination of Hole 424A sediments. (1) Sample 424A-1-1, 89-91 cm: "ringlet-aspect" mineral against diffused aspect of the background. (2) Same sample: an illite or chlorite type particle at the expense of which fibers grown in radially. (3) Sample 424A-1-2, 75-77 $\mathrm{cm}$ : detail of radial growth of fibers. (4) Same sample: general aspect of fibers. (5) Sample 424A-2-2, 9-11 cm: sample composed of two phases: "ringlet-aspect" particles and lath-particles. (6) Same sample: other aspect of the same preparation. (7) Sample 424A-2-3, 4I-43 cm: "ringlet-aspect"' particles are absent, but we can see many radially growing particles. (8) Same sample: detail of such radial growth. 

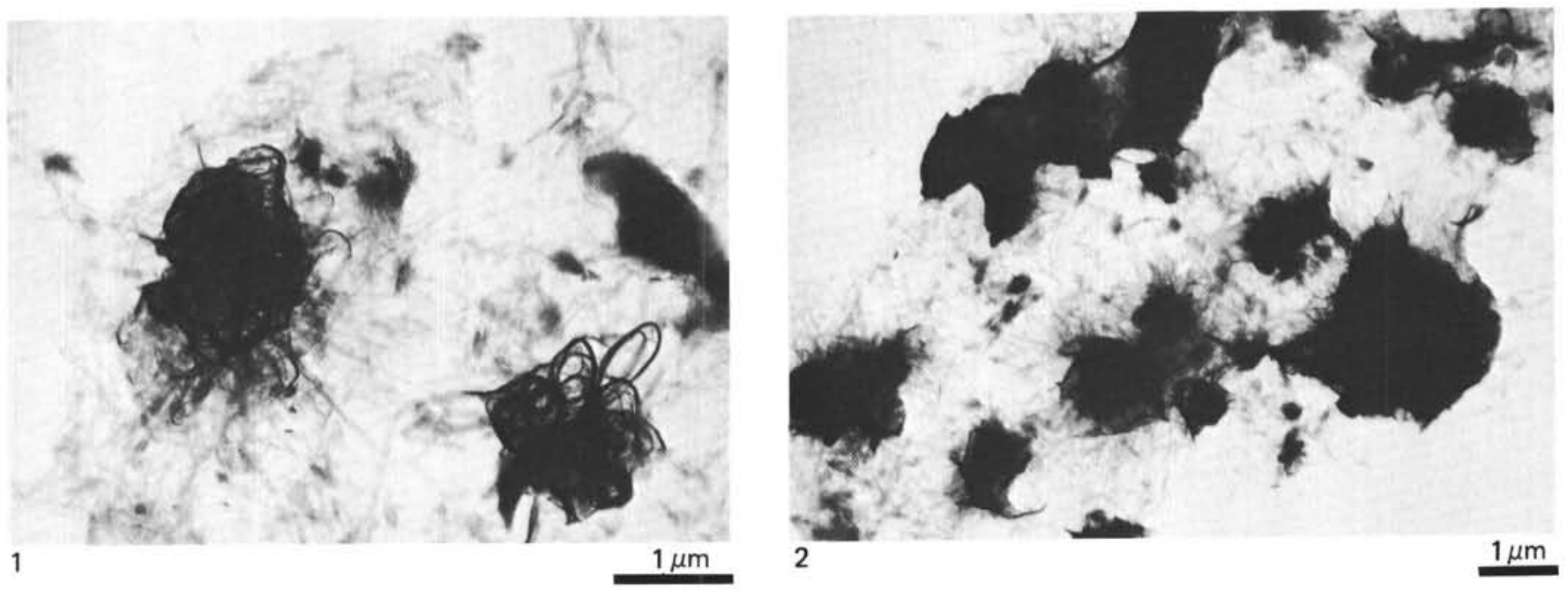

Figure 10. Electron microscope examination of Hole 424B sediments. (I) Sampie 424B-2-3, 70-72 cm: "ringietaspect" minerals. It seems that lath-minerals are radially growing at the expense of "ringiet-minerais." (2) Sampie $424 B-2-4,42-44 \mathrm{~cm}$ : progressive transformation of "ringlet-minerals" to lath-minerais.
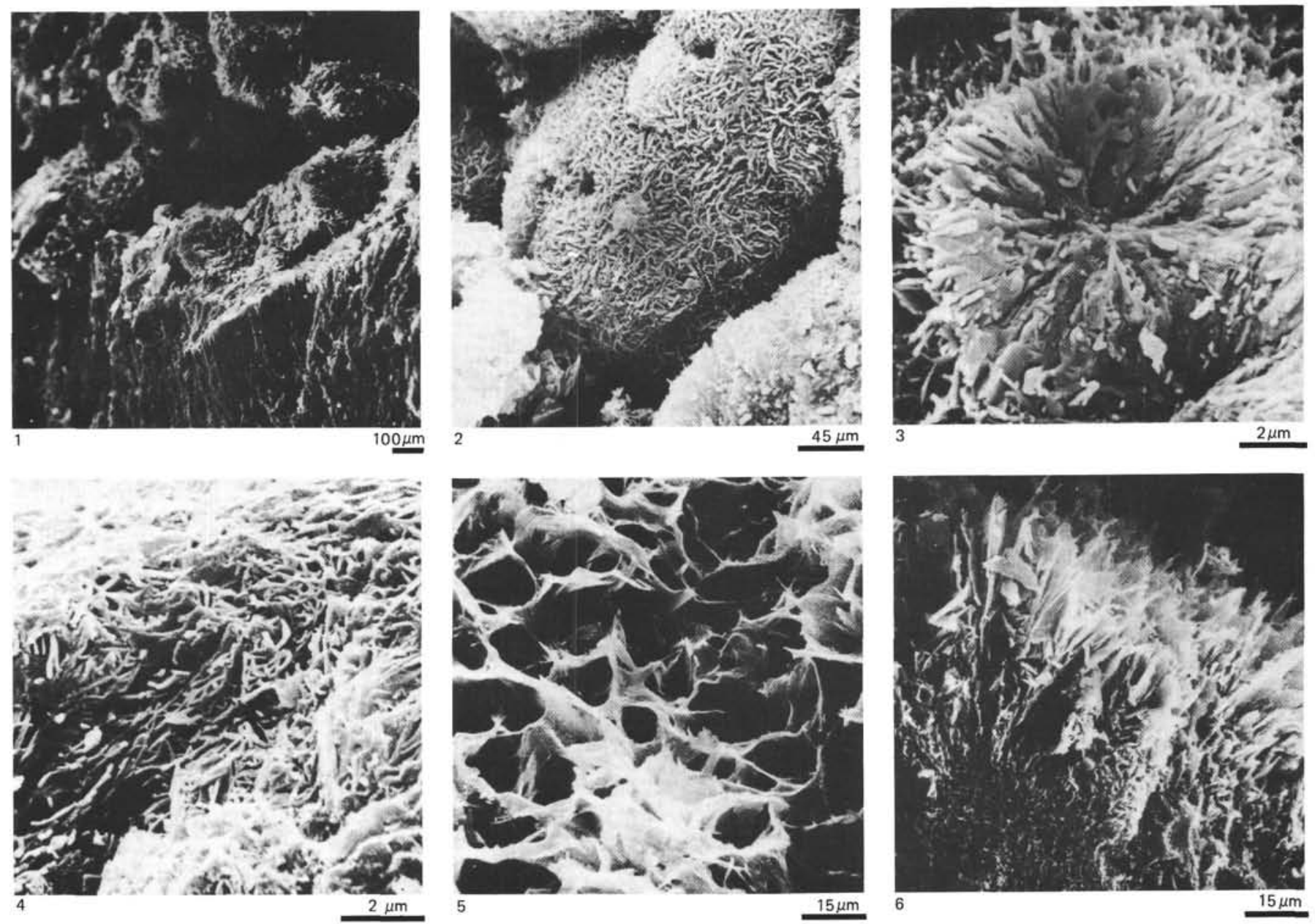

Figure 11. Morphology of Mn slabs (SEM examination). (1) Sample 424A-1,CC: surface of a fracture in a Mn slab: Mn concretions can be seen in the upper part; Mn blades in the lower part. (2) Same sample: aspect of a Mn concretion. (3) Same sample: radial spherical aggregates of the constituent Mn blades. (4) Same sample: compact piling of Mn blades. (5 and 6) Same sample: basis of the compact piling: detail of the aspect of Mn blades. 

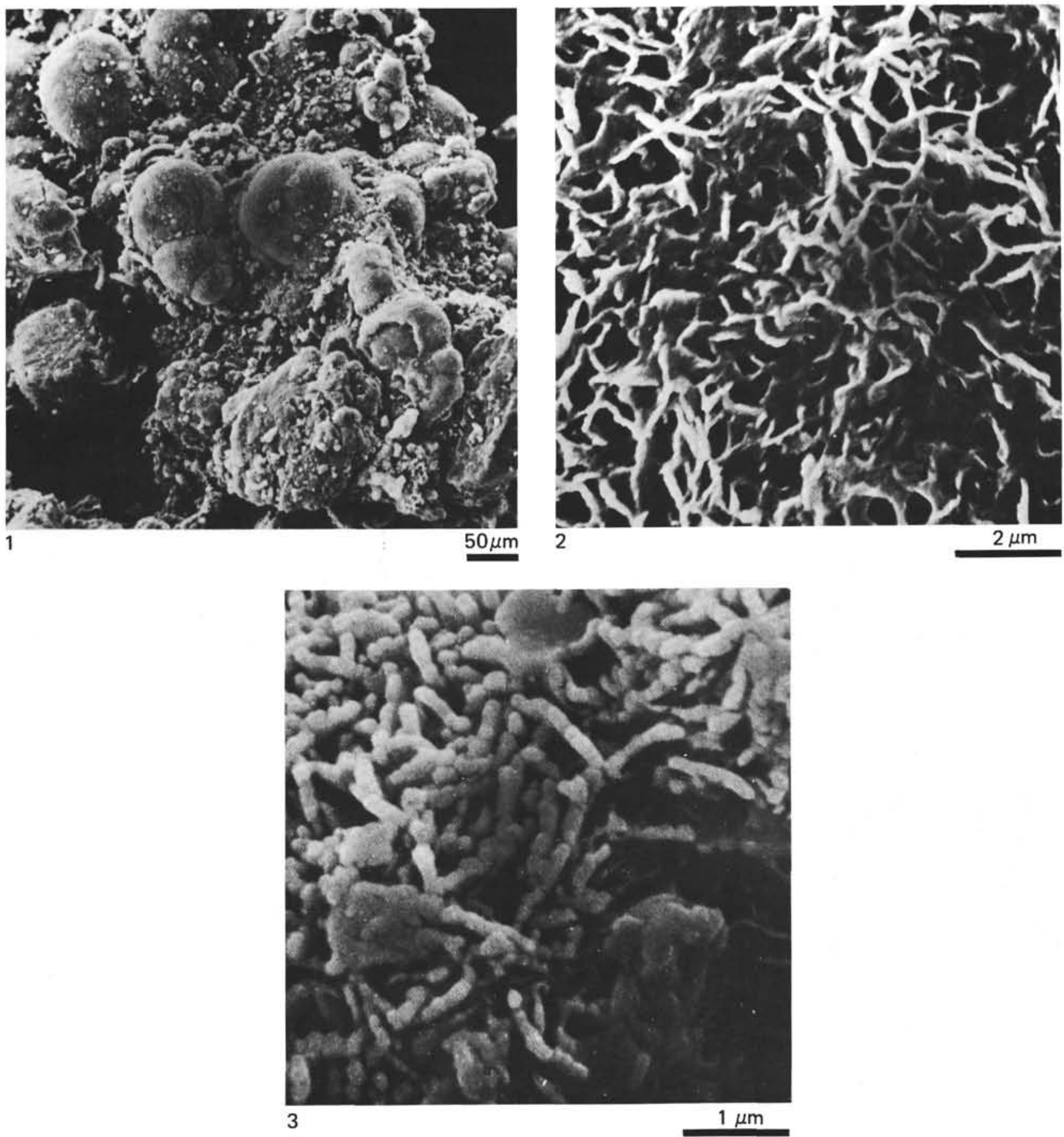

Figure 12. Morphology of Mn concretions (SEM examination). (1) Sample 424-1-1, 2-4 cm: Mn concretions growing on the surface of a smectite granule. (2) Same sample: structural detail of these Mn concretions. (3) Same sample: detail of another structure of Mn concretions. 

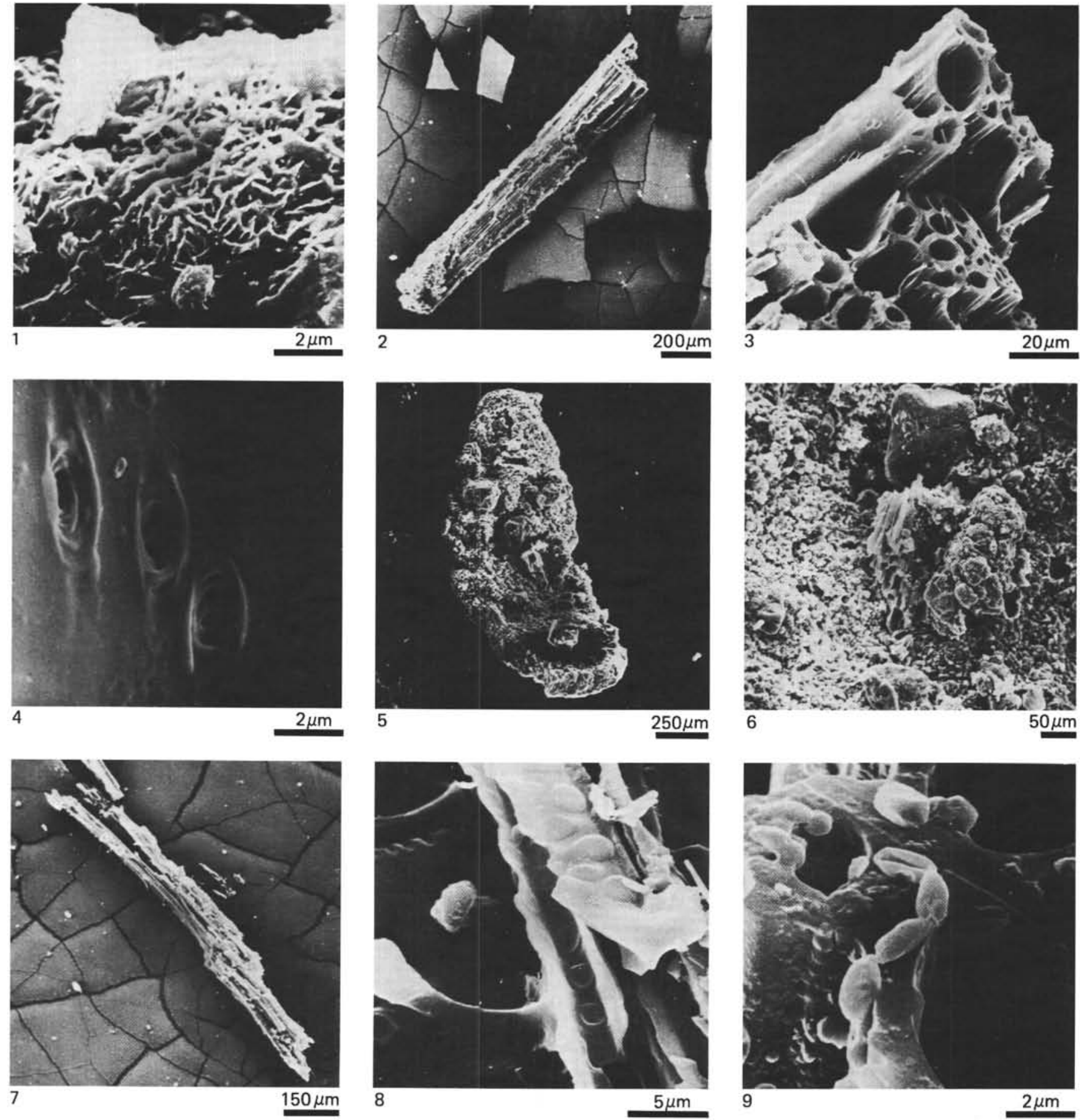

Figure 13. Non-mineral structures (plant remains) recovered from Mn concretions (SEM examination). (1) Sample 424-1-1, 2-4 cm: todorokite blades growing out of a wood particle (see photograph 2). (2) Same sample: black wood particle. Photograph I is the lower end, photograph 3 the upper end. (3) Same sample: detail of tubular structure (angiosperme wood ?). (4) Same sample: puncture in the wall of a wood cellule. (5) Same sample: general aspect: smectitic granule with fragment of wood in the middle part and Mn oxides. (6) Same sample: wood fragment and smectites. (7) Same sample: another fragment of wood. (8) Same sample: detail of 7, punctures in the cellule wall. (9) Same sample detail: bacteria (?) - pollc. (?). 
Sample 424-111, 24-26 cm

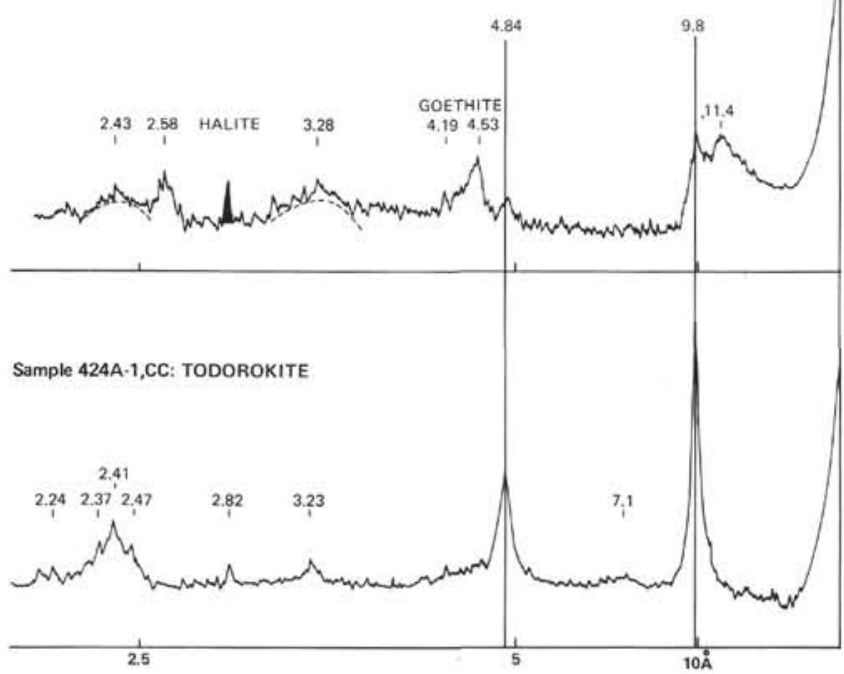

Figure 14. X-ray diffraction charts on two types of $\mathrm{Mn}$ rich deposits. Sample 424-1-1, 24-26 cm corresponds to a type I sediment composed of smectite granules and Mn crusts. Sample 424A-1, CC corresponds to an isolated Mn slab composed only of todorokite.

Sample 424A-1,CC: TODOROKITE

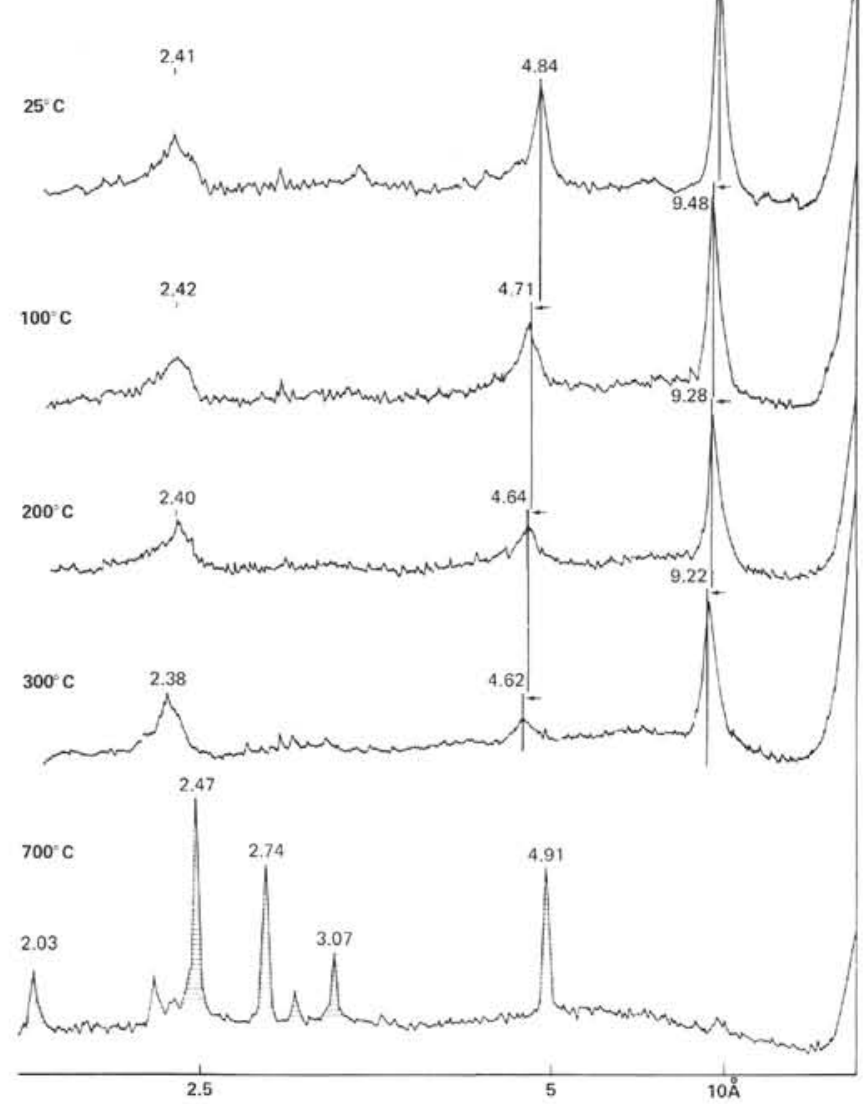

Figure 15. Series of $X$-ray diffraction charts obtained after progressive heating of a todorokite mineral.

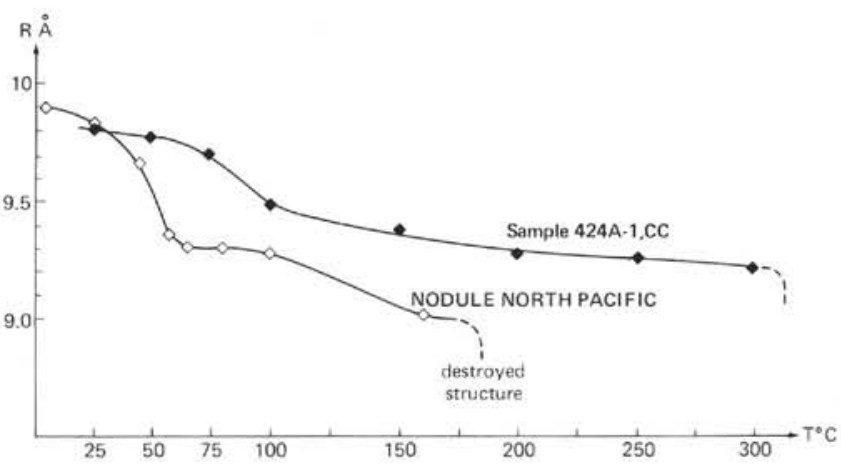

Figure 16. Position of principal todorokite peak versus temperature; example of todorokite from an hydrothermal deposit and from a Mn-nodule.
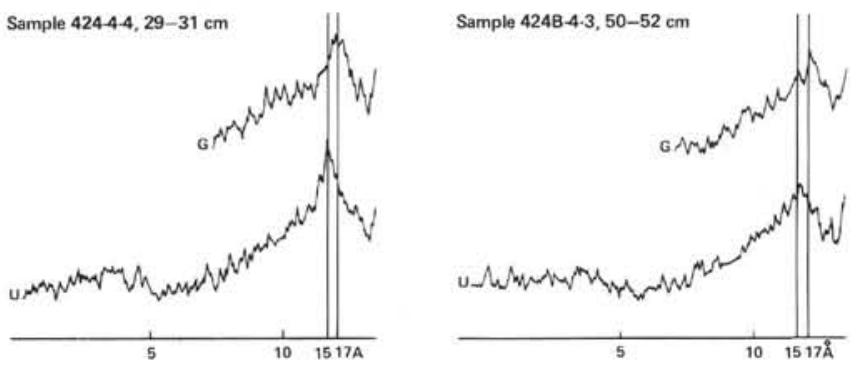

U: UNTREATED G: GLYCOL TREATED

Figure 17. X-ray diffraction charts of the clay fraction of foraminifer-nannofossil ooze.

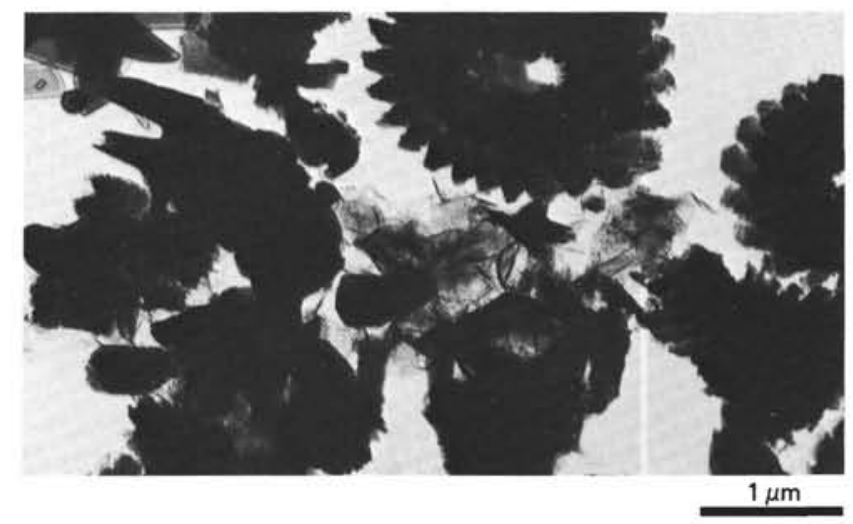

Figure 18. Electron microscope examination of smectites from foraminiferal-nannofossil ooze. 
TABLE 1

Bulk Chemical Analyses of Sediments from Hole 424, Leg 54 (wt. \%)

\begin{tabular}{lllllllllllrr}
\hline $\begin{array}{c}\text { Sample } \\
\text { (Interval in cm) }\end{array}$ & $\mathrm{SiO}_{2}$ & $\mathrm{Al}_{2} \mathrm{O}_{3}$ & $\mathrm{MgO}$ & $\mathrm{CaO}$ & $\mathrm{Fe}_{2} \mathrm{O}_{3}$ & $\mathrm{Mn}_{3} \mathrm{O}_{4}$ & $\mathrm{TiO}_{2}$ & $\mathrm{BaO}$ & $\mathrm{Na}_{2} \mathrm{O}$ & $\mathrm{K}_{2} \mathrm{O}$ & $\begin{array}{r}\text { L.O.I. } \\
\left(\mathrm{at} 1000^{\circ} \mathrm{C}\right)\end{array}$ & $\begin{array}{r}\mathrm{TOTAL} \\
\hline 1-1,2-4\end{array}$ \\
\hline $1,2.2$ & 0.5 & 3.72 & 1.4 & 26.1 & 11.00 & 0.02 & 0.08 & 1.58 & 1.53 & 10.24 & 98.27 \\
$1-128-130$ & 47.1 & $0.2 \mathrm{H}$ & 3.59 & 0.6 & 29.1 & 5.81 & $0.02 \mathrm{H}$ & 0.05 & 1.43 & 1.68 & 8.51 & 98.09 \\
$1-2,50-52$ & 51.6 & $0.2 \mathrm{H}$ & 3.60 & 0.3 & 30.0 & 0.543 & $0.02 \mathrm{H}$ & 0.02 & 0.89 & 1.34 & 6.86 & 95.32 \\
$2-1,56-58$ & 52.5 & 0.2 & 4.14 & 0.3 & 31.2 & 0.124 & 0.02 & $0.01 \mathrm{H}$ & 1.76 & 3.38 & 6.40 & 100.06 \\
$2-2,11-13$ & 52.3 & $0.2 \mathrm{H}$ & 4.41 & 0.3 & 30.6 & 0.184 & $0.02 \mathrm{H}$ & 0.02 & 2.08 & 3.39 & 6.79 & 100.15 \\
$2-3,126-128$ & 50.3 & 0.4 & 4.16 & 0.4 & 31.6 & 0.212 & 0.03 & $0.01 \mathrm{H}$ & 1.83 & 3.38 & 6.78 & 99.08 \\
$2-3,136-138$ & 19.3 & 2.9 & 2.56 & 30.4 & 6.9 & 0.301 & 0.14 & 0.22 & 0.58 & 0.16 & 35.45 & 99.03 \\
$2-4,80-82$ & 43.2 & 0.5 & 3.72 & 1.6 & 36.3 & 0.149 & 0.03 & 0.03 & 1.70 & 3.23 & 8.38 & 98.81 \\
$2-5,140-142$ & 24.6 & 4.4 & 2.69 & 26.1 & 7.3 & 0.264 & 0.22 & 0.32 & 0.78 & 0.21 & 31.31 & 98.21 \\
$2-6,89-91$ & 28.6 & 3.1 & 3.16 & 22.7 & 11.1 & 0.256 & 0.13 & 0.25 & 0.62 & 0.13 & 27.93 & 97.98 \\
$3-1,42-44$ & 50.1 & 1.1 & 4.76 & 0.6 & 27.7 & 2.10 & 0.05 & 0.03 & 2.57 & 3.45 & 7.38 & 99.88 \\
$3-1,134-136$ & 20.5 & 2.9 & 2.17 & 28.7 & 7.6 & 0.243 & 0.12 & 0.27 & 0.27 & $0.05 \mathrm{H}$ & 31.98 & 94.95 \\
$3-4,73-75$ & 17.6 & 3.4 & 2.71 & 32.3 & 5.4 & 0.331 & 0.14 & 0.21 & 0.09 & $0.05 \mathrm{H}$ & 32.62 & 94.79 \\
$3-5,40-42$ & 35.5 & 1.2 & 3.48 & 15.4 & 20.1 & 0.246 & 0.05 & 0.12 & 1.74 & 1.18 & 19.36 & 98.38 \\
$3-6,90-92$ & 12.9 & 2.4 & 2.57 & 36.1 & 3.8 & 0.510 & 0.11 & 0.20 & 0.09 & $0.05 \mathrm{H}$ & 34.29 & 93.05 \\
$4-1,72-74$ & 39.7 & 1.1 & 3.26 & 13.2 & 22.6 & 0.867 & 0.06 & 0.10 & 1.91 & 1.55 & 16.74 & 101.03 \\
$4-2,60-62$ & 17.0 & 1.6 & 1.55 & 35.8 & 7.9 & 1.29 & 0.09 & 0.12 & 0.29 & 0.14 & 31.92 & 97.67 \\
$4-6,39-41$ & 12.3 & 2.6 & 1.73 & 41.5 & 2.2 & 1.03 & 0.10 & 0.10 & 0.06 & $0.05 \mathrm{H}$ & 36.00 & 97.55 \\
\hline
\end{tabular}

Note: Total iron was calculated as $\mathrm{Fe}_{2} \mathrm{O}_{3}$, total manganese as $\mathrm{Mn}_{3} \mathrm{O}_{4} . \mathrm{H}=$ value below detection limit.

TABLE 2

Bulk Chemical Analyses of Sediments from Hole 424, Leg 54 (wt. \%), Recalculated on CaO-Free Basis

\begin{tabular}{lcccccccccc}
\hline $\begin{array}{c}\text { Sample } \\
\text { (Interval in cm) }\end{array}$ & $\mathrm{SiO}_{2}$ & $\mathrm{Al}_{2} \mathrm{O}_{3}$ & $\mathrm{MgO}$ & $\mathrm{Ie}_{2} \mathrm{O}_{3}$ & $\mathrm{Mn}_{3} \mathrm{O}_{4}$ & $\mathrm{TiO}_{2}$ & $\mathrm{BaO}$ & $\mathrm{Na}_{2} \mathrm{O}$ & $\mathrm{K}_{2} \mathrm{O}$ & $\begin{array}{r}\text { L.O.I. } \\
\text { (at } 1000^{\circ} \mathrm{C} \text { ) }\end{array}$ \\
\hline $1-1,2-4$ & 44.06 & 0.522 & 3.88 & 27.25 & 11.48 & 0.02 & 0.08 & 1.64 & 1.59 & 9.54 \\
$1-1,128-130$ & 48.54 & 0.206 & 3.70 & 29.99 & 5.98 & 0.02 & 0.05 & 1.47 & 1.73 & 8.28 \\
$1-2,50-52$ & 54.43 & 0.211 & 3.79 & 31.65 & 0.57 & 0.02 & 0.02 & 0.93 & 1.41 & 6.98 \\
$2-1,56-58$ & 52.75 & 0.200 & 4.15 & 31.34 & 0.12 & 0.02 & 0.01 & 1.76 & 3.39 & 6.19 \\
$2-2,11-13$ & 52.50 & 0.200 & 4.42 & 30.71 & 0.18 & 0.02 & 0.02 & 2.08 & 3.40 & 6.57 \\
$2-3,126-128$ & 51.13 & 0.406 & 4.22 & 32.12 & 0.21 & 0.03 & 0.01 & 1.86 & 3.43 & 6.57 \\
$2-3,136-138$ & 43.14 & 6.48 & 5.72 & 15.42 & 0.67 & 0.31 & 0.49 & 1.29 & 0.35 & 25.83 \\
$2-4,80-82$ & 45.02 & 0.521 & 3.87 & 37.83 & 0.15 & 0.03 & 0.03 & 1.77 & 3.36 & 7.42 \\
$2-5,140-142$ & 47.67 & 8.52 & 5.21 & 14.14 & 0.51 & 0.42 & 0.62 & 1.51 & 0.40 & 20.92 \\
$2-6,89-91$ & 49.79 & 5.39 & 5.50 & 19.32 & 0.44 & 0.33 & 0.43 & 1.07 & 0.22 & 17.56 \\
$3-1,42-44$ & 50.70 & 1.11 & 4.81 & 28.03 & 2.12 & 0.05 & 0.03 & 2.60 & 3.49 & 6.99 \\
$3-1,134-136$ & 46.91 & 6.63 & 4.96 & 17.39 & 0.55 & 0.27 & 0.61 & 0.61 & 0.11 & 21.56 \\
$3-4,73-75$ & 47.43 & 9.16 & 7.30 & 14.55 & 0.89 & 0.37 & 0.56 & 0.24 & 0.13 & 19.49 \\
$3-5,40-42$ & 50.08 & 1.69 & 4.91 & 28.35 & 0.34 & 0.07 & 0.16 & 245 & 1.66 & 10.23 \\
$3-6,90-92$ & 45.14 & 8.39 & 8.99 & 13.29 & 1.78 & 0.38 & 0.69 & 0.31 & 0.17 & 20.70 \\
$4-1,72-74$ & 51.25 & 1.42 & 4.20 & 29.17 & 1.11 & 0.07 & 0.12 & 2.46 & 2.00 & 8.21 \\
$4-2,60-62$ & 50.39 & 4.74 & 4.59 & 23.42 & 3.82 & 0.26 & 0.35 & 0.85 & 0.41 & 11.20 \\
$4-6,39-41$ & 52.49 & 11.09 & 7.38 & 9.38 & 4.39 & 0.42 & 0.42 & 0.25 & 0.21 & 14.42 \\
\hline
\end{tabular}

TABLE 3

Bulk Chemical Analyses of Sediments from Hole 424A, Leg 54 (wt. \%)

\begin{tabular}{|c|c|c|c|c|c|c|c|c|c|c|c|c|}
\hline $\begin{array}{c}\text { Sample } \\
\text { (Interval in } \mathrm{cm} \text { ) }\end{array}$ & $\mathrm{SiO}_{2}$ & $\mathrm{Al}_{2} \mathrm{O}_{3}$ & $\mathrm{MgO}$ & $\mathrm{CaO}$ & $\mathrm{Fe}_{2} \mathrm{O}_{3}$ & $\mathrm{Mn}_{3} \mathrm{O}_{4}$ & $\mathrm{TiO}_{2}$ & $\mathrm{BaO}$ & $\mathrm{Na}_{2} \mathrm{O}$ & $\mathrm{K}_{2} \mathrm{O}$ & $\begin{array}{c}\text { L.O.I. } \\
\text { (at } 1000^{\circ} \mathrm{C} \text { ) }\end{array}$ & TOTAL \\
\hline $1-1,89-91$ & 45.3 & 4.1 & 3.90 & 3.8 & 19.0 & 4.72 & 0.18 & 0.18 & 3.58 & 2.14 & 12.99 & 99.92 \\
\hline $1-1,146-148$ & 25.5 & 5.4 & 3.58 & 15.9 & 6.5 & 15.74 & 0.23 & 0.48 & 1.67 & 0.34 & 24.95 & 90.28 \\
\hline $1-2,75-77$ & 46.3 & 0.6 & 3.58 & 1.1 & 27.6 & 6.02 & 0.03 & 0.09 & 2.33 & 2.56 & 8.37 & 98.55 \\
\hline $2-1,39-41$ & 9.4 & 1.7 & 1.24 & 40.8 & 1.6 & 1.26 & 0.07 & 0.23 & 0.11 & $0.05 \mathrm{H}$ & 37.25 & 93.69 \\
\hline $2-2,9-11$ & 51.4 & 0.2 & 4.43 & 0.6 & 29.0 & 0.115 & $0.02 \mathrm{H}$ & $0.01 \mathrm{H}$ & 2.20 & 3.91 & 6.81 & 98.81 \\
\hline $2-2,71-73$ & 19.8 & 1.8 & 2.55 & 29.4 & 8.8 & 0.382 & 0.09 & 0.20 & 0.24 & $0.05 \mathrm{H}$ & 32.77 & 96.00 \\
\hline $2-3,141-143$ & 44.0 & 0.5 & 3.88 & 7.5 & 25.0 & 0.205 & 0.03 & 0.03 & 1.68 & 3.25 & 11.58 & 97.63 \\
\hline $2-4,29-31$ & 6.1 & 1.5 & 1.58 & 47.8 & 1.5 & 0.737 & 0.06 & 0.10 & 0.20 & 0.14 & 38.17 & 97.85 \\
\hline $3-3,30-32$ & 4.1 & 0.8 & 1.42 & 46.7 & 0.9 & 1.23 & 0.04 & 0.03 & 0.11 & 0.06 & 38.78 & 94.18 \\
\hline
\end{tabular}

Note: Total iron was calculated as $\mathrm{Fe}_{2} \mathrm{O}_{3}$, total manganese as $\mathrm{Mn}_{3} \mathrm{O}_{4} \cdot \mathrm{H}=$ value below detection limit. 
TABLE 4

Bulk Chemical Analyses of Sediments from Hole 424A, Leg 54 (wt. \%), Recalculated on CaO-Free Basis

\begin{tabular}{lrrrrrrrrrr}
\hline $\begin{array}{c}\text { Sample } \\
\text { (Interval in cm) }\end{array}$ & $\mathrm{SiO}_{2}$ & $\mathrm{Al}_{2} \mathrm{O}_{3}$ & $\mathrm{MgO}$ & $\mathrm{Fe}_{2} \mathrm{O}_{3}$ & $\mathrm{Mn}_{3} \mathrm{O}_{4}$ & $\mathrm{TiO}_{2}$ & $\mathrm{BaO}$ & $\mathrm{Na}_{2} \mathrm{O}$ & $\mathrm{K}_{2} \mathrm{O}$ & $\begin{array}{r}\text { L.O.I. } \\
\text { (at } 1000^{\circ} \mathrm{C} \text { ) }\end{array}$ \\
\hline $1-1,89-91$ & 48.64 & 4.40 & 4.18 & 20.40 & 5.06 & 0.19 & 0.19 & 3.84 & 2.29 & 10.74 \\
$1-1,146-148$ & 41.20 & 8.72 & 5.78 & 10.50 & 25.43 & 0.37 & 0.77 & 2.69 & 0.54 & 20.12 \\
$1-2,75-77$ & 47.93 & 0.62 & 3.70 & 28.57 & 6.23 & 0.03 & 0.09 & 2.41 & 2.65 & 7.77 \\
$2-1,39-41$ & 45.14 & 8.16 & 5.95 & 7.68 & 6.05 & 0.33 & 1.10 & 0.52 & 0.24 & 24.88 \\
$2-2,9-11$ & 52.58 & 0.20 & 4.53 & 29.67 & 0.11 & 0.02 & 0.01 & 2.25 & 4.00 & 6.48 \\
$2-2,71-73$ & 45.52 & 4.13 & 5.86 & 20.23 & 0.87 & 0.20 & 0.45 & 0.55 & 0.11 & 22.2 \\
$2-3,141-143$ & 52.23 & 0.59 & 4.60 & 29.67 & 0.24 & 0.03 & 0.03 & 1.99 & 3.85 & 6.74 \\
$2-4,29-31$ & 48.88 & 12.02 & 12.66 & 12.02 & 5.90 & 0.48 & 0.80 & 1.60 & 1.12 & 4.80 \\
$3-3,30-32$ & 38.05 & 7.42 & 13.18 & 8.35 & 11.41 & 0.37 & 0.27 & 1.02 & 0.55 & 19.24 \\
\hline
\end{tabular}

TABLE 5

Bulk Chemical Analyses of Sediments from Hole 424B, Leg 54 (wt. \%)

\begin{tabular}{llllrllllllrr}
\hline $\begin{array}{c}\text { Sample } \\
\text { (Interval in cm) }\end{array}$ & $\mathrm{SiO}_{2}$ & $\mathrm{Al}_{2} \mathrm{O}_{3}$ & $\mathrm{MgO}$ & $\mathrm{CaO}$ & $\mathrm{Fe}_{2} \mathrm{O}_{3}$ & $\mathrm{Mn}_{3} \mathrm{O}_{4}$ & $\mathrm{TiO}_{2}$ & $\mathrm{BaO}$ & $\mathrm{Na}_{2} \mathrm{O}$ & $\mathrm{K}_{2} \mathrm{O}$ & $\begin{array}{c}\text { L.O.I. } \\
\left(\text { at } 1000^{\circ} \mathrm{C}\right)\end{array}$ & \begin{tabular}{c}
$\mathrm{TOTAL}$ \\
\hline $1-1,30-32$
\end{tabular} \\
\hline 16.2 & 1.7 & 1.54 & 36.4 & 2.8 & 0.533 & 0.08 & 0.28 & 0.10 & $0.05 \mathrm{H}$ & 37.44 & 97.07 \\
$1-2,112-114$ & 53.9 & 0.2 & 3.70 & 0.4 & 31.2 & 0.234 & $0.02 \mathrm{H}$ & 0.02 & 2.02 & 2.62 & 6.44 & 100.77 \\
$2-1,60-62$ & 52.6 & 0.4 & 3.76 & 0.3 & 31.1 & 0.068 & 0.03 & 0.06 & 2.37 & 2.56 & 6.74 & 100.02 \\
$2-2,50-52$ & 53.9 & 0.5 & 3.60 & 0.4 & 29.5 & 0.065 & 0.04 & 0.05 & 2.47 & 2.96 & 6.37 & 99.90 \\
$2-2,125-127$ & 47.8 & 2.2 & 3.83 & 0.9 & 24.6 & 0.148 & 0.09 & 0.24 & 3.99 & 3.07 & 9.22 & 96.15 \\
$2-3,40-42$ & 52.1 & 0.9 & 3.72 & 0.6 & 29.1 & 0.074 & 0.04 & 0.09 & 2.75 & 2.93 & 7.07 & 99.40 \\
$2-4,42-44$ & 51.8 & 1.9 & 3.85 & 0.5 & 28.6 & 0.091 & 0.07 & 0.13 & 2.84 & 3.61 & 6.73 & 99.97 \\
$2-6,17-19$ & 52.9 & $0.2 \mathrm{H}$ & 3.60 & 0.5 & 30.5 & 0.065 & $0.02 \mathrm{H}$ & $0.01 \mathrm{H}$ & 2.14 & 3.59 & 6.09 & 99.49 \\
$3-1,30-32$ & 39.8 & 1.3 & 4.09 & 10.2 & 21.4 & 0.105 & 0.06 & 0.15 & 3.00 & 2.15 & 16.62 & 98.86 \\
$3-2,17-19$ & 52.8 & 0.3 & 4.53 & 0.6 & 30.6 & 0.068 & $0.02 \mathrm{H}$ & $0.01 \mathrm{H}$ & 1.97 & 3.59 & 6.16 & 100.61 \\
$3-3,17-19$ & 42.2 & 0.7 & 4.11 & 10.8 & 22.5 & 0.113 & 0.04 & 0.09 & 2.71 & 2.14 & 15.31 & 100.73 \\
$3-4,63-65$ & 51.8 & $0.2 \mathrm{H}$ & 4.45 & 0.6 & 29.2 & 0.053 & $0.02 \mathrm{H}$ & $0.01 \mathrm{H}$ & 1.90 & 4.50 & 6.15 & 98.82 \\
$3-4,72-74$ & 25.3 & 1.6 & 2.94 & 27.5 & 11.8 & 0.348 & 0.07 & 0.15 & 0.69 & 0.46 & 27.85 & 98.70 \\
$3-4,128-130$ & 42.1 & 0.4 & 4.22 & 9.4 & 23.6 & 0.191 & 0.02 & 0.04 & 2.63 & 2.60 & 14.61 & 99.82 \\
$3-5,132-134$ & 39.1 & 0.5 & 4.82 & 12.3 & 22.6 & 0.216 & 0.02 & 0.02 & 2.12 & 1.66 & 15.96 & 99.32 \\
$4-2,40-42$ & 7.1 & 1.2 & 1.90 & 45.2 & 2.8 & 0.908 & 0.07 & 0.07 & 0.06 & $0.05 \mathrm{H}$ & 37.53 & 96.92 \\
\hline
\end{tabular}

Note: Total iron was calculated as $\mathrm{Fe}_{2} \mathrm{O}_{3}$, total manganese as $\mathrm{Mn}_{3} \mathrm{O}_{4} . \mathrm{H}=$ value below detection limit.

TABLE 6

Bulk Chemical Analyses of Sediments from Hole 424B, Leg 54 (wt. \%), Recalculated on CaO-Free Basis

\begin{tabular}{lcccccccccr}
\hline $\begin{array}{c}\text { Sample } \\
\text { (Interval in cm) }\end{array}$ & $\mathrm{SiO}_{2}$ & $\mathrm{Al}_{2} \mathrm{O}_{3}$ & $\mathrm{MgO}$ & $\mathrm{Fe}_{2} \mathrm{O}_{3}$ & $\mathrm{Mn}_{3} \mathrm{O}_{4}$ & $\mathrm{TiO}_{2}$ & $\mathrm{BaO}$ & $\mathrm{Na}_{2} \mathrm{O}$ & $\mathrm{K}_{2} \mathrm{O}$ & $\begin{array}{r}\text { L.O.I. } \\
\text { (at } 1000^{\circ} \mathrm{C} \text { ) }\end{array}$ \\
\hline $1-1,30-32$ & 50.53 & 5.30 & 4.80 & 8.73 & 1.66 & 0.24 & 0.87 & 0.31 & 0.15 & 27.54 \\
$1-2,112-114$ & 53.87 & 0.19 & 3.69 & 31.18 & 0.23 & 0.01 & 0.01 & 2.01 & 2.61 & 6.12 \\
$2-1,60-62$ & 52.87 & 0.40 & 3.77 & 31.26 & 0.06 & 0.03 & 0.06 & 2.38 & 2.57 & 6.53 \\
$2-2,50-52$ & 54.34 & 0.50 & 3.62 & 29.74 & 0.06 & 0.04 & 0.05 & 2.49 & 2.98 & 6.10 \\
$2-2,125-127$ & 50.55 & 2.32 & 4.05 & 26.02 & 0.15 & 0.09 & 0.25 & 4.22 & 3.24 & 9.00 \\
$2-3,40-42$ & 52.98 & 0.91 & 3.78 & 29.59 & 0.07 & 0.04 & 0.09 & 2.79 & 2.97 & 6.71 \\
$2-4,42-44$ & 52.28 & 1.91 & 3.88 & 28.86 & 0.09 & 0.07 & 0.13 & 2.86 & 3.64 & 6.39 \\
$2-4,17-19$ & 53.65 & 0.20 & 3.65 & 30.93 & 0.06 & 0.02 & 0.01 & 2.17 & 3.64 & 5.77 \\
$3-1,30-32$ & 49.35 & 1.61 & 5.07 & 26.53 & 0.13 & 0.07 & 0.18 & 3.72 & 2.66 & 10.66 \\
$3-2,17-19$ & 53.04 & 0.30 & 4.55 & 30.74 & 0.06 & 0.02 & 0.01 & 1.97 & 3.60 & 5.71 \\
$3-3,17-19$ & 51.81 & 0.85 & 5.04 & 27.62 & 0.13 & 0.04 & 0.11 & 3.32 & 2.62 & 8.37 \\
$3-4,63-65$ & 52.99 & 0.20 & 4.55 & 29.87 & 0.05 & 0.02 & 0.01 & 1.94 & 4.60 & 5.80 \\
$3-4,72-74$ & 51.02 & 3.22 & 5.92 & 23.79 & 0.70 & 0.14 & 0.30 & 1.39 & 0.92 & 12.57 \\
$3-4,128-130$ & 50.70 & 0.48 & 5.08 & 28.42 & 0.23 & 0.02 & 0.04 & 3.16 & 3.13 & 8.69 \\
$3-5,132-134$ & 50.54 & 0.64 & 6.23 & 29.21 & 0.27 & 0.02 & 0.02 & 2.74 & 2.14 & 8.13 \\
$4-2,40-42$ & 43.84 & 7.41 & 11.73 & 17.29 & 5.60 & 0.43 & 0.43 & 0.37 & 0.30 & 12.36 \\
\hline
\end{tabular}


TABLE 7

Bulk Chemical Analyses of Sediments from Hole 424C, Leg 54 (wt. \%)

\begin{tabular}{|c|c|c|c|c|c|c|c|c|c|c|c|c|}
\hline $\begin{array}{c}\text { Sample } \\
\text { (Interval in } \mathrm{cm} \text { ) }\end{array}$ & $\mathrm{SiO}_{2}$ & $\mathrm{Al}_{2} \mathrm{O}_{3}$ & $\mathrm{MgO}$ & $\mathrm{CaO}$ & $\mathrm{Fe}_{2} \mathrm{O}_{3}$ & $\mathrm{Mn}_{3} \mathrm{O}_{4}$ & $\mathrm{TiO}_{2}$ & $\mathrm{BaO}$ & $\mathrm{Na}_{2} \mathrm{O}$ & $\mathrm{K}_{2} \mathrm{O}$ & $\begin{array}{l}\text { L.O.I. } \\
\text { (at } 1000^{\circ} \mathrm{C} \text { ) }\end{array}$ & TOTAL \\
\hline $1-4,49-51$ & 17.5 & 3.0 & 1.20 & 37.6 & 2.2 & 0.290 & 0.13 & 0.24 & $0.05 \mathrm{H}$ & $0.05 \mathrm{H}$ & 34.57 & 96.68 \\
\hline $1-5,49-51$ & 15.1 & 2.0 & 1.19 & 38.5 & 1.3 & 0.294 & 0.09 & 0.21 & 0.05 & $0.05 \mathrm{H}$ & 36.17 & 94.91 \\
\hline
\end{tabular}

Note: Total iron was calculated as $\mathrm{Fe}_{2} \mathrm{O}_{3}$, total manganese as $\mathrm{Mn}_{3} \mathrm{O}_{4}$.

TABLE 8

Bulk Chemical Analyses of Sediments from Hole 424C, Leg 54 (wt. \%), Recalculated on CaO-Free Basis

\begin{tabular}{lrrrrrrrrrr}
\hline $\begin{array}{c}\text { Sample } \\
\text { (Interval in cm) }\end{array}$ & $\mathrm{SiO}_{2}$ & $\mathrm{Al}_{2} \mathrm{O}_{3}$ & $\mathrm{MgO}$ & $\mathrm{Fe}_{2} \mathrm{O}_{3}$ & $\mathrm{Mn}_{3} \mathrm{O}_{4}$ & $\mathrm{TiO}_{2}$ & $\mathrm{BaO}$ & $\mathrm{Na}_{2} \mathrm{O}$ & $\mathrm{K}_{2} \mathrm{O}$ & $\begin{array}{c}\text { L.O.I. } \\
\text { (at } 1000^{\circ} \mathrm{C} \text { ) }\end{array}$ \\
\hline $1-4,49-51$ & 59.26 & 10.16 & 4.06 & 7.45 & 0.98 & 0.44 & 0.81 & 0.16 & 0.16 & 16.98 \\
$1-5,49-51$ & 57.74 & 7.64 & 4.55 & 4.97 & 1.12 & 0.34 & 0.80 & 0.19 & 0.19 & 22.59 \\
\hline
\end{tabular}

TABLE 9

Trace Element Concentrations (ppm), Hole 424, Leg 54

\begin{tabular}{lrrrrrrrrrrrr}
\hline $\begin{array}{c}\text { Sample } \\
\text { (Interval in cm) }\end{array}$ & $\mathrm{Sr}$ & $\mathrm{Ba}$ & $\mathrm{V}$ & $\mathrm{Ni}$ & $\mathrm{Co}$ & $\mathrm{Cr}$ & $\mathrm{B}$ & $\mathrm{Ti}$ & $\mathrm{Zn}$ & $\mathrm{Ga}$ & $\mathrm{Cu}$ & $\mathrm{Pb}$ \\
\hline $1-1,2-4$ & 121 & 666 & 26 & 31 & 4 & $5 \mathrm{H}$ & 316 & 92 & 59 & 30 & 71 & 237 \\
$1-1,128-130$ & 94 & 384 & 20 & 13 & $2 \mathrm{H}$ & $5 \mathrm{H}$ & 312 & 39 & 33 & 14 & 59 & 162 \\
$1-2,50-52$ & 51 & 149 & 22 & 8 & $2 \mathrm{H}$ & 8 & 313 & 46 & 35 & $2 \mathrm{H}$ & 48 & 121 \\
$2-1,56-58$ & 44 & 26 & 26 & 6 & $2 \mathrm{H}$ & 10 & 317 & 48 & 38 & $2 \mathrm{H}$ & 37 & 107 \\
$2-2,11-13$ & 64 & 37 & 25 & 10 & 3 & 9 & 281 & 93 & 53 & $2 \mathrm{H}$ & 30 & 55 \\
$2-3,126-128$ & 49 & 97 & 29 & 14 & 5 & 9 & 332 & 161 & 84 & $2 \mathrm{H}$ & 40 & 52 \\
$2-3,136-138$ & 1931 & 2652 & 87 & 73 & 30 & 29 & 114 & $\mathrm{OZ}$ & 99 & $2 \mathrm{H}$ & 19 & 2 \\
$2-4,80-82$ & 75 & 149 & 19 & 10 & $2 \mathrm{H}$ & 8 & 371 & 151 & 42 & $2 \mathrm{H}$ & 62 & 27 \\
$2-5,140-142$ & 1762 & 3815 & 162 & 86 & 27 & 37 & 100 & $\mathrm{OZ}$ & 154 & 4 & 22 & 3 \\
$2-6,89-91$ & 2790 & 3989 & 138 & 237 & 27 & 40 & 145 & $\mathrm{OZ}$ & 359 & 13 & 51 & 36 \\
$3-1,42-44$ & 92 & 255 & 35 & 33 & 4 & 13 & 310 & 490 & 156 & 8 & 77 & 130 \\
$3-1,134-136$ & 1877 & 3861 & 72 & 145 & 8 & 27 & 106 & $\mathrm{OZ}$ & 145 & 5 & 45 & 29 \\
$3-4,73-75$ & 1490 & 2421 & 65 & 150 & 15 & 31 & $5 \mathrm{H}$ & $\mathrm{OZ}$ & 87 & 2 & 42 & 3 \\
$3-5,40-42$ & 459 & 720 & $5 \mathrm{H}$ & 76 & $2 \mathrm{H}$ & 11 & 262 & $\mathrm{OZ}$ & 98 & $2 \mathrm{H}$ & 60 & 113 \\
$3-6,90-92$ & 1330 & 2094 & 32 & 194 & 10 & 14 & $5 \mathrm{H}$ & $\mathrm{OZ}$ & 108 & $2 \mathrm{H}$ & 36 & $2 \mathrm{H}$ \\
$4-1,72-74$ & 472 & 671 & 12 & 56 & $2 \mathrm{H}$ & 15 & 264 & $\mathrm{OZ}$ & 95 & $2 \mathrm{H}$ & 73 & 135 \\
$4-2,60-62$ & 1304 & 1192 & $5 \mathrm{H}$ & 72 & $2 \mathrm{H}$ & 7 & 100 & $\mathrm{OZ}$ & 52 & $2 \mathrm{H}$ & 20 & 26 \\
$4-6,39-41$ & 1407 & 1124 & 17 & 55 & $2 \mathrm{H}$ & 15 & $5 \mathrm{H}$ & $\mathrm{OZ}$ & 45 & 2 & 32 & 10 \\
\hline
\end{tabular}

Note: $\mathrm{H}=$ Value below detection limit. $\mathrm{OZ}=$ Element determined in major oxides $(\%)$.

TABLE 10

Trace Element Concentrations (ppm), Hole 424A, Leg 54

\begin{tabular}{lrrrrrrrrrrrr}
\hline $\begin{array}{c}\text { Sample } \\
\text { (nterval in cm) }\end{array}$ & $\mathrm{Sr}$ & $\mathrm{Ba}$ & $\mathrm{V}$ & $\mathrm{Ni}$ & $\mathrm{Co}$ & $\mathrm{Cr}$ & $\mathrm{B}$ & $\mathrm{Ti}$ & $\mathrm{Zn}$ & $\mathrm{Ga}$ & $\mathrm{Cu}$ & $\mathrm{Pb}$ \\
\hline $1-1,89-90$ & 222 & 1622 & 87 & 118 & 10 & 29 & 203 & 1553 & 205 & 15 & 133 & 262 \\
$1-1,146-148$ & 1775 & 4253 & 90 & 322 & 35 & 58 & 97 & & 175 & & 151 & 115 \\
$1-2,75-77$ & 156 & 938 & 34 & 65 & 8 & 11 & 335 & 259 & 183 & 21 & 115 & $537 \mathrm{E}$ \\
$2-1,39-41$ & 1624 & 2778 & 5 & 126 & $2 \mathrm{H}$ & 8 & $5 \mathrm{H}$ & $\mathrm{OZ}$ & 80 & $2 \mathrm{H}$ & 55 & 11 \\
$2-2,9-11$ & 69 & 311 & 37 & 34 & 15 & 10 & 451 & 193 & 108 & $2 \mathrm{H}$ & 61 & 111 \\
$2-2,71-73$ & 1396 & 2340 & 18 & 138 & 36 & 17 & 120 & $\mathrm{OZ}$ & 127 & $2 \mathrm{H}$ & 53 & 23 \\
$2-3,141-143$ & 336 & 480 & 22 & 83 & 22 & 13 & 558 & 265 & 75 & $2 \mathrm{H}$ & 74 & 160 \\
$2-4,29-31$ & 1734 & 1011 & $5 \mathrm{H}$ & 84 & 46 & 12 & $5 \mathrm{H}$ & $\mathrm{OZ}$ & 60 & $2 \mathrm{H}$ & 57 & $2 \mathrm{H}$ \\
$3-3,30-32$ & 1494 & 372 & $5 \mathrm{H}$ & 22 & $2 \mathrm{H}$ & $5 \mathrm{H}$ & $5 \mathrm{H}$ & $\mathrm{OZ}$ & 33 & $2 \mathrm{H}$ & 43 & 16 \\
\hline
\end{tabular}

Note: $\mathrm{H}=$ Value below detection limit. $\mathrm{OZ}=$ Element determined in major oxides $(\%)$. 
TABLE 11

Trace Element Concentrations (ppm), Hole 424B, Leg 54

\begin{tabular}{lrrrrrrrrrrrr}
\hline $\begin{array}{c}\text { Sample } \\
\text { (Interval in cm) }\end{array}$ & $\mathrm{Sr}$ & $\mathrm{Ba}$ & $\mathrm{V}$ & $\mathrm{Ni}$ & $\mathrm{Co}$ & $\mathrm{Cr}$ & $\mathrm{B}$ & $\mathrm{Ti}$ & $\mathrm{Zn}$ & $\mathrm{Ga}$ & $\mathrm{Cu}$ & $\mathrm{Pb}$ \\
\hline $1-1,30-32$ & 1559 & 3136 & 67 & 162 & $2 \mathrm{H}$ & 17 & 38 & $\mathrm{OZ}$ & 33 & $2 \mathrm{H}$ & 3 & $2 \mathrm{H}$ \\
$1-2,112-114$ & 64 & 213 & 31 & 34 & 4 & 9 & 311 & 128 & 127 & $2 \mathrm{H}$ & 95 & 75 \\
$2-1,60-62$ & 70 & 400 & 21 & 14 & 2 & 12 & 247 & 160 & 111 & $2 \mathrm{H}$ & 54 & 72 \\
$2-2,50-52$ & 75 & 450 & 27 & 16 & 3 & 13 & 298 & 259 & 118 & $2 \mathrm{H}$ & 100 & 62 \\
$2-2,125-127$ & 245 & 2814 & 67 & 40 & 10 & 19 & 361 & 941 & 126 & $2 \mathrm{H}$ & 134 & 39 \\
$2-3,40-42$ & 141 & 1192 & 38 & 20 & 6 & 16 & 297 & 500 & 147 & 4 & 100 & 56 \\
$2-4,42-44$ & 150 & 1481 & 39 & 25 & 5 & 14 & 392 & 698 & 154 & $2 \mathrm{H}$ & 94 & 71 \\
$2-6,17-19$ & 143 & 162 & 28 & 21 & 7 & 12 & 313 & 92 & 218 & 3 & 48 & 62 \\
$3-1,30-32$ & 662 & 1843 & 53 & 29 & 8 & 19 & 337 & 648 & 103 & 2 & 79 & 78 \\
$3-2,17-19$ & 65 & 71 & 30 & 31 & 7 & 49 & 286 & 174 & 130 & $2 \mathrm{H}$ & 115 & 62 \\
$3-3,17-19$ & 599 & 1002 & 38 & 33 & 8 & 16 & 315 & 297 & 118 & 2 & 61 & 76 \\
$3-4,63-65$ & 69 & 77 & 29 & 24 & 7 & 8 & 481 & 55 & 133 & 5 & 41 & 44 \\
$3-4,72-74$ & 1355 & 1660 & 25 & 60 & $2 \mathrm{H}$ & 22 & 270 & $\mathrm{OZ}$ & 97 & $2 \mathrm{H}$ & 28 & 9 \\
$3-4,128-130$ & 489 & 523 & 48 & 70 & 10 & 12 & 496 & 212 & 100 & 3 & 65 & 85 \\
$3-5,132-134$ & 327 & 135 & $5 \mathrm{H}$ & 27 & $2 \mathrm{H}$ & 5 & 479 & $\mathrm{OZ}$ & 23 & 10 & 58 & 49 \\
$4-2,40-42$ & 1424 & 711 & $5 \mathrm{H}$ & 52 & $2 \mathrm{H}$ & $5 \mathrm{H}$ & $5 \mathrm{H}$ & $\mathrm{OZ}$ & 26 & $2 \mathrm{H}$ & 11 & $2 \mathrm{H}$ \\
\hline
\end{tabular}

Note: $\mathrm{H}=$ Value below detection limit. $\mathrm{OZ}=$ Element determined in major oxides $(\%)$.

TABLE 12

Trace Element Concentrations (ppm), Hole 424C, Leg 54

\begin{tabular}{lcccccccccccc}
\hline $\begin{array}{c}\text { Sample } \\
\text { (Interval in cm) }\end{array}$ & $\mathrm{Sr}$ & $\mathrm{Ba}$ & $\mathrm{V}$ & $\mathrm{Ni}$ & $\mathrm{Co}$ & $\mathrm{Cr}$ & $\mathrm{B}$ & $\mathrm{Ti}$ & $\mathrm{Zn}$ & $\mathrm{Ga}$ & $\mathrm{Cu}$ & $\mathrm{Pb}$ \\
\hline $1-4,49-51$ & 1834 & 2899 & 64 & 131 & $2 \mathrm{H}$ & 24 & $5 \mathrm{H}$ & $\mathrm{OZ}$ & 28 & $2 \mathrm{H}$ & $2 \mathrm{H}$ & $2 \mathrm{H}$ \\
$1-5,49-51$ & 1502 & 2329 & 32 & 140 & $2 \mathrm{H}$ & 19 & 51 & $\mathrm{OZ}$ & 14 & $2 \mathrm{H}$ & 3 & $2 \mathrm{H}$ \\
\hline
\end{tabular}

Note: $\mathrm{H}=$ Value below detection limit. $\mathrm{OZ}=$ Element determined in major oxides $(\%)$.

TABLE 13

Ratios Between Different Elements, Hole 424, Leg 54

\begin{tabular}{lrccc}
\hline $\begin{array}{c}\text { Sample } \\
\text { (Interval in cm) }\end{array}$ & $\mathrm{Si} / \mathrm{Al}$ & $\mathrm{Fe}_{2} \mathrm{O}_{3} / \mathrm{Mn}_{3} \mathrm{O}_{4}$ & $\mathrm{Fe}_{2} \mathrm{O}_{3} / \mathrm{Al}_{2} \mathrm{O}_{3}$ & $\mathrm{Mn}_{3} \mathrm{O}_{4} / \mathrm{Al}_{2} \mathrm{O}_{3}$ \\
\hline $1-1,2-4$ & 74.27 & 26.10 & 52.20 & 22.00 \\
$1-1,128-130$ & 207.24 & 5.00 & 145.50 & 29.05 \\
$1-2,50-52$ & 227.04 & 55.24 & 150.00 & 2.71 \\
$2-1,56-58$ & 231.00 & 251.61 & 156.00 & 0.62 \\
$2-2,11-13$ & 230.12 & 166.30 & 153.00 & 0.92 \\
$2-3,126-128$ & 110.66 & 149.05 & 79.00 & 0.53 \\
$2-3,136-138$ & 5.85 & 22.92 & 2.37 & 0.10 \\
$2-4,80-82$ & 76.03 & 243.62 & 72.60 & 0.29 \\
$2-5,140-142$ & 4.92 & 27.65 & 1.65 & 0.06 \\
$2-6,89-91$ & 8.11 & 43.35 & 3.58 & 0.08 \\
$3-1,42-44$ & 40.08 & 13.19 & 25.18 & 1.90 \\
$3-1,134-136$ & 6.22 & 31.27 & 2.62 & 0.08 \\
$3-4,73-75$ & 4.55 & 16.31 & 1.58 & 0.09 \\
$3-5,40-42$ & 26.03 & 81.70 & 16.75 & 0.20 \\
$3-6,90-92$ & 4.73 & 7.45 & 1.58 & 0.21 \\
$4-1,72-74$ & 31.76 & 26.06 & 20.54 & 0.78 \\
$4-2,60-62$ & 9.35 & 6.12 & 4.93 & 0.80 \\
$4-6,39-41$ & 4.16 & 2.13 & 0.84 & 0.39 \\
\hline
\end{tabular}

TABLE 14

Ratios Between Different Elements, Hole 424A, Leg 54

\begin{tabular}{lrccc}
\hline $\begin{array}{c}\text { Sample } \\
\text { (Interval in cm) }\end{array}$ & $\mathrm{Si} / \mathrm{Al}$ & $\mathrm{Fe}_{2} \mathrm{O}_{3} / \mathrm{Mn}_{3} \mathrm{O}_{4}$ & $\mathrm{Fe}_{2} \mathrm{O}_{3} / \mathrm{Al}_{2} \mathrm{O}_{3}$ & $\mathrm{Mn}_{3} \mathrm{O}_{4} / \mathrm{Al}_{2} \mathrm{O}_{3}$ \\
\hline $1-1,89-91$ & 8.83 & 4.02 & 4.63 & 1.15 \\
$1-1,146-148$ & 4.15 & 0.41 & 1.20 & 2.91 \\
$1-2,75-77$ & 67.90 & 4.58 & 46.00 & 10.03 \\
$2-1,39-41$ & 4.86 & 1.27 & 0.94 & 0.74 \\
$2-2,9-11$ & 226.16 & 252.17 & 145.00 & 0.57 \\
$2-2,71-73$ & 9.68 & 23.03 & 4.88 & 0.21 \\
$2-3,141-143$ & 77.44 & 121.95 & 50.00 & 0.41 \\
$2-4,29-31$ & 3.57 & 2.03 & 1.00 & 0.49 \\
$3-3,30-32$ & 4.51 & 0.73 & 1.12 & 1.53 \\
\hline
\end{tabular}

TABLE 15

Ratios Between Different Elements, Hole 424B, Leg 54

\begin{tabular}{lrccc}
\hline $\begin{array}{c}\text { Sample } \\
\text { Interval in cm) }\end{array}$ & $\mathrm{Si} / \mathrm{Al}$ & $\mathrm{Fe}_{2} \mathrm{O}_{3} / \mathrm{Mn}_{3} \mathrm{O}_{4}$ & $\mathrm{Fe}_{2} \mathrm{O}_{3} / \mathrm{Al}_{2} \mathrm{O}_{3}$ & $\mathrm{Mn}_{3} \mathrm{O}_{4} / \mathrm{Al}_{2} \mathrm{O}_{3}$ \\
\hline $1-1,30-32$ & 8.38 & 5.25 & 1.64 & 0.314 \\
$1-2,112-114$ & 237.16 & 133.33 & 156.00 & 1.17 \\
$2-1,60-62$ & 115.72 & 457.35 & 77.75 & 0.17 \\
$2-2,50-52$ & 94.86 & 453.84 & 59.00 & 0.13 \\
$2-2,125-127$ & 19.12 & 166.21 & 11.18 & 0.06 \\
$2-3,40-42$ & 50.94 & 393.24 & 32.33 & 0.08 \\
$2-4,42-44$ & 23.99 & 314.28 & 15.05 & 0.04 \\
$2-6,17-19$ & 232.76 & 469.23 & 152.50 & 0.32 \\
$3-1,30-32$ & 26.94 & 203.81 & 16.46 & 0.08 \\
$3-2,17-19$ & 154.88 & 450.00 & 102.00 & 0.22 \\
$3-3,17-19$ & 53.05 & 199.11 & 32.14 & 0.16 \\
$3-4,63-65$ & 227.92 & 550.94 & 146.00 & 0.26 \\
$3-4,72-74$ & 13.91 & 33.90 & 7.37 & 0.21 \\
$3-4,128-130$ & 92.62 & 123.56 & 59.00 & 0.47 \\
$3-5,132-134$ & 68.81 & 104.63 & 45.20 & 0.43 \\
$4-2,40-42$ & 5.20 & 3.08 & 2.33 & 0.75 \\
\hline
\end{tabular}

TABLE 16

Ratios Between Different Elements, Hole 424C, Leg 54

Sample

(Interval in cm) $\quad \mathrm{Si} / \mathrm{Al} \quad \mathrm{Fe}_{2} \mathrm{O}_{3} / \mathrm{Mn}_{3} \mathrm{O}_{4} \quad \mathrm{Fe}_{2} \mathrm{O}_{3} / \mathrm{Al}_{2} \mathrm{O}_{3} \quad \mathrm{Mn}_{3} \mathrm{O}_{4} / \mathrm{Al}_{2} \mathrm{O}_{3}$

$\begin{array}{lllll}1-4,49-51 & 5.13 & 7.58 & 0.73 & 0.09 \\ 1-5,49-51 & 6.64 & 4.42 & 0.65 & 0.14\end{array}$ 
This defines a $\mathrm{Si}-\mathrm{Fe}-\mathrm{K}$ phase. On a $\mathrm{CaO}-0$ basis, $\mathrm{Mg}$ shows a good correlation with $\mathrm{Al}$ in type III deposits. The noncarbonate phase of this type of deposit is thus: $\mathrm{Si}-\mathrm{Al}-\mathrm{Mg}-(\mathrm{Fe})$.

\section{$\mathrm{Ca}$}

This element signifies the presence of a carbonate biogenic phase. It is absent in type I and II sediments. The proportion of $\mathrm{CaO}$ in interbedded layers near the base of the holes reflects the mixed characteristics between types II and III. The study of the variation of major oxides permits establishment of a geochemical profile of the samples:

Type I: $[\mathrm{Si}-\mathrm{Fe}-\mathrm{K}]+\mathrm{Na}+\mathrm{Mn} ; \mathrm{Si} / \mathrm{Al}$ high

Type II: $[\mathrm{Si}-\mathrm{Fe}-\mathrm{K}]+\mathrm{Na} ; \mathrm{Si} / \mathrm{Al}$ high

Type III: [Ca biogenic) $+\mathrm{Si}-\mathrm{Al}-\mathrm{Mg}-(\mathrm{Fe})$

\section{Trace Elements}

The study of their abundances and relationships with major oxides enables us to establish that the silica phases from types I and II on the one hand and the aluminosilicates phase of type II on the other hand, are fundamentally different. We can identify several associations of trace elements.

\section{$S r-B a$}

These elements characterize the carbonate facies (type III), which is a well-known fact (El Wakeel and Riley, 1961; Brongersma-Sanders, 1967).

\section{$\mathrm{Ti}, \mathrm{V}, \mathrm{Ni}, \mathrm{Co}$, and $\mathrm{Cr}$}

These elements are present in very low concentrations in type I and II sediments ( $\mathrm{V}$ about $25 \mathrm{ppm}$, Ni less than $50 \mathrm{ppm}$; Co and $\mathrm{Cr}$ less than $10 \mathrm{ppm}$ ) and in higher amounts in type III. This may indicate the presence of some small amount of volcanic glass or the capacity of this clay fraction to "incorporate" such trace elements. It is well known that clay minerals are rich in such trace elements (Ataman, 1964; Karpoff et al., 1973).

\section{$\mathrm{B}, \mathrm{Pb}$, and $\mathrm{Cu}$}

These elements have a different relationship from that of the forementioned trace elements and characterize type I and II sediments (B about $300 \mathrm{ppm}, \mathrm{Pb}$ about $130 \mathrm{ppm}$, and $\mathrm{Cu}$ about $50 \mathrm{ppm}) . \mathrm{Pb}$ and $\mathrm{Cu}$ must be substituted by $\mathrm{Fe}$, while $\mathrm{B}$ should have a high concentration in view of the argillaceous composition of this facies.

\section{Other Trace Elements}

$\mathrm{Ga}$ is present in very low concentration, probably due to the low concentration of $\mathrm{Al}$ in this type of sediment.

$\mathrm{Zn}$ occurs sometimes in high concentrations in type I or II deposits, and may then be correlated with $\mathrm{Cu}$ and Ni. The reason for this is not clear (glass? organisms?).

With an increase in $\mathrm{Mn}$, we note an increase also in $\mathrm{Ba}, \mathrm{Ni}, \mathrm{Co}, \mathrm{Cu}$, and $\mathrm{Pb}$, indicating that these elements may occur in different mineral phases (silicates, oxides, and carbonates).

In conclusion, these studies have enabled us to determine that clay minerals of types I and II are very low in transition elements, except $\mathrm{Cu}$ and $\mathrm{Pb}$, and also that these clays absorb B. Smectites of type III are rich in transition elements such as $\mathrm{Ti}, \mathrm{Ni}, \mathrm{V}$, and $\mathrm{Co}$. Mn oxides are a trap for elements which are derived from carbonate and from silicate phases $(\mathrm{Ba}, \mathrm{Ni}, \mathrm{Co}$, and $\mathrm{Cu})$.

\section{Polished Sections (SEM Studies)}

Polished sections, after induration of the hydrothermal material, have been studied with a Cameca 07 scanning electron microscope to determine the location of some elements of type II granules. An example is given in Figure 24. The granules (a) contain a predominance of two elements, $\mathrm{Si}$ and $\mathrm{Fe}$. $\mathrm{Al}$ is absent, as was shown with the Tracor system. (The latter also confirmed results of the chemical analyses.) Our studies have led to the following conclusions:

$\mathrm{K}$ and $\mathrm{Mg}$ are also associated, but in a low proportion with $\mathrm{Si}-\mathrm{Fe}$.

$\mathrm{Ca}$ is present in two phases: associated with $\mathrm{Si}-\mathrm{Fe}-$ $\mathrm{Mg}-\mathrm{K}$ and alone, in those granules where fragments of biological origin occur.

$\mathrm{Na}$ and $\mathrm{Cl}$ are associated in a very restricted phase (b) and correspond to halite. We could not establish whether this halite is incorporated into a type (a) granule or whether it is in a surface layer surrounding this granule. This leads us to conclude that the relationship between $\mathrm{Si}-\mathrm{Fe}-\mathrm{K}-(\mathrm{Mg})$ and $\mathrm{Na}$ detected by chemical analysis reflects two different phases: smectites and halites.

Phase (c) corresponds to induration resin.

These observations are in good agreement with the chemical analysis, proving that the granules are $\mathrm{Si}-\mathrm{Fe}$ associated with $\mathrm{K}$ and $\mathrm{Mg}$, and also that they are very poor in $\mathrm{Al}$.

\section{REE Distribution}

We were interested to study the evolution of the distribution of REE between the fresh underlying basalt, the hydrothermal deposits, and the foraminifernannofossil ooze. Measurements were made by neutron activation analysis after the method described by Treuil et al. (1973), with an accuracy of about 20 per cent. In spite of the very low REE concentrations (which are sometimes near the limit of detection for elements such as $\mathrm{Tb}$ ) in these sediments, their distribution is fairly uniform.

\section{In Basalts}

In each of the three holes, a sample of fresh basalt has been analyzed for REE distribution. The specimens were, respectively, Samples 424-5-4, 2-5 cm (Piece 1), 424A-4-1, 3-5 cm (Piece 1), and 424B-5-1, 67-70 cm (Piece 9). Results are reported in Tables 17, 18, and 19, respectively, for the three holes, and the chondritic normalized patterns in Figure 25. The REE contents of these basalts are of the order of some tens of ppm, and the distribution curves are very regular. They are 


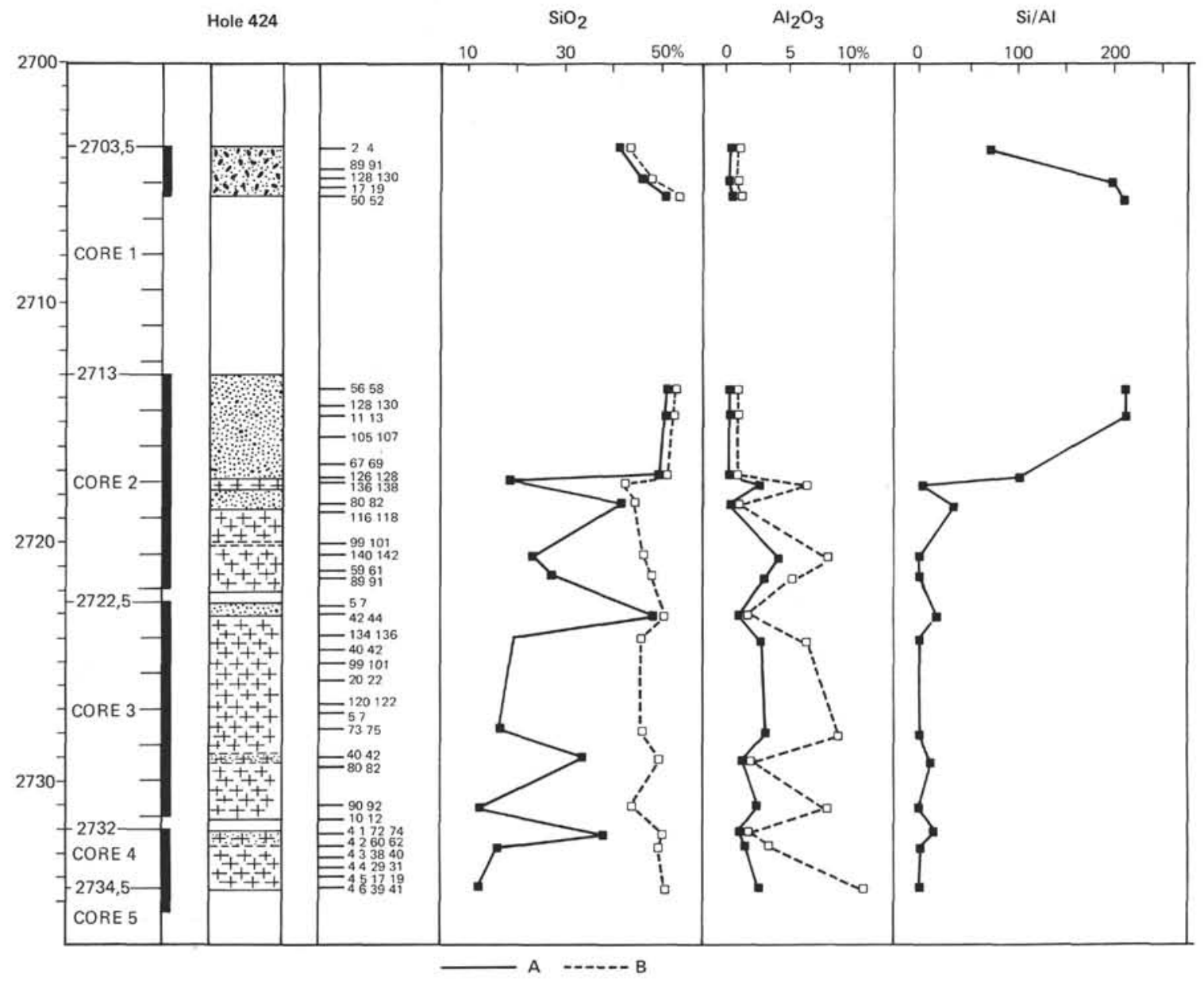

Figure 19. Variations on the major oxides along Hole 424. (A) bulk sediment. (B) Analysis recalculated on $\mathrm{CaO}-\mathrm{O}$. 


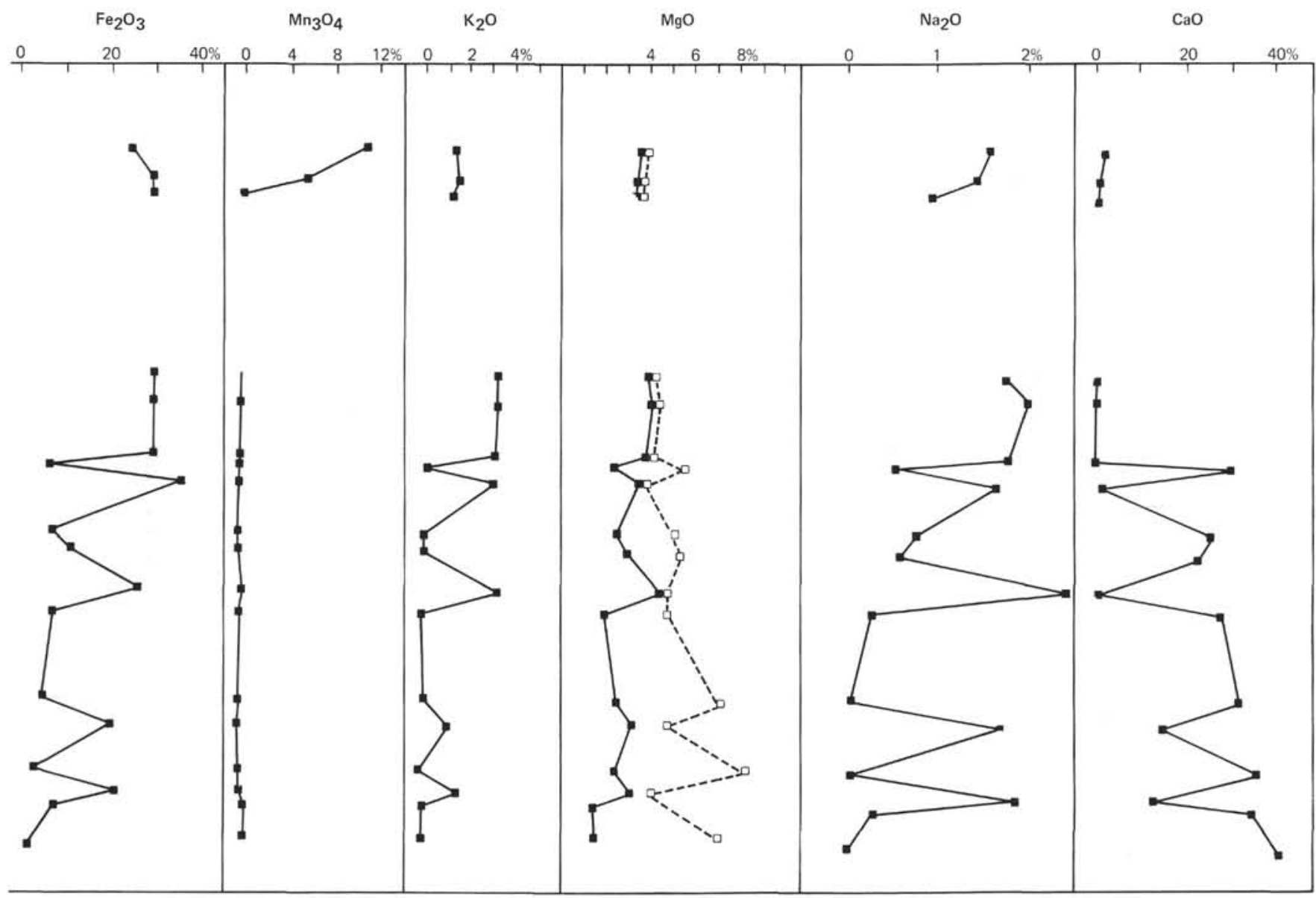

Figure 19. (Continued). 


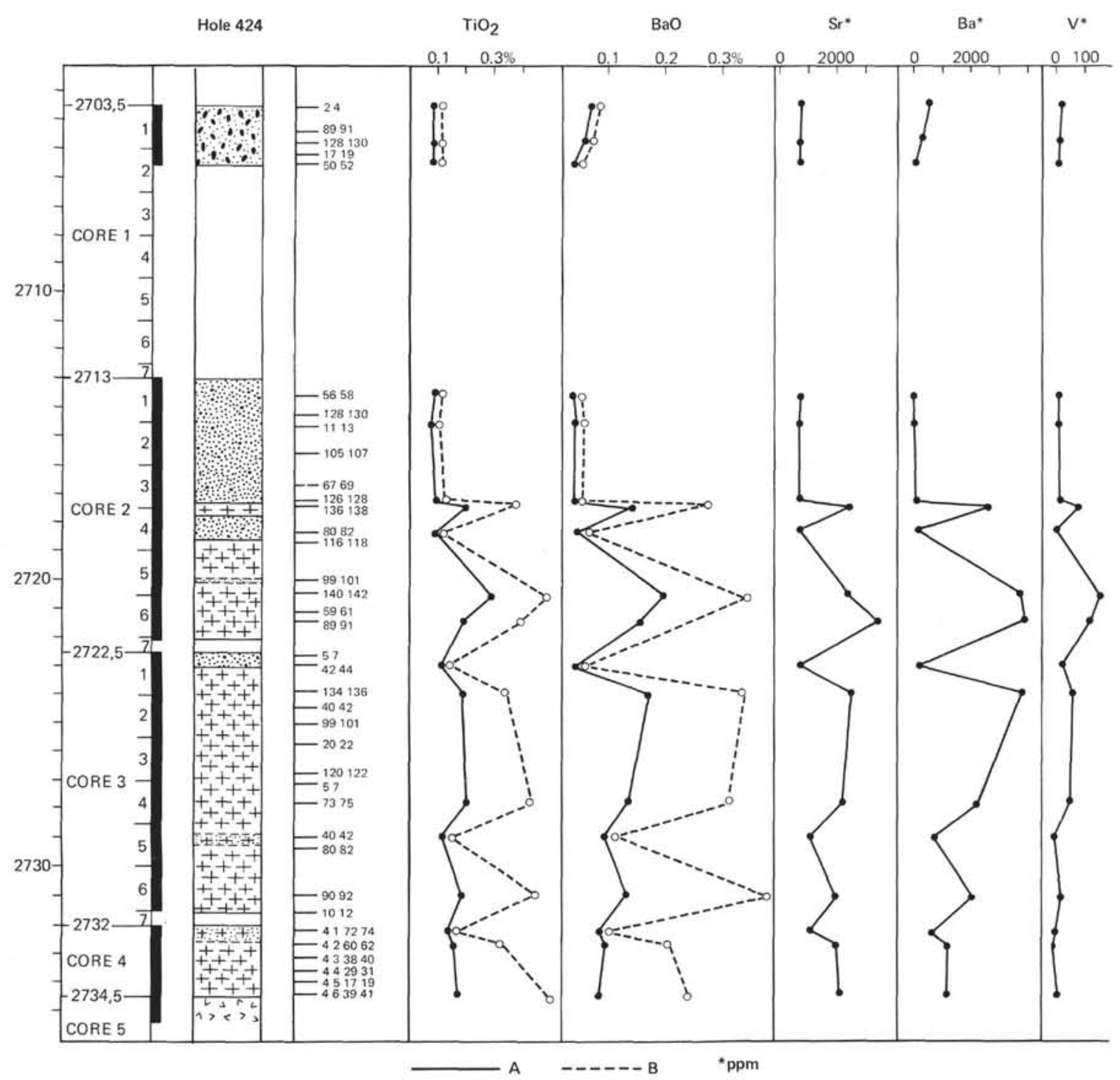

Figure 20. Variations of trace elements along Hole 424. 
HYDROTHERMAL DEPOSITS

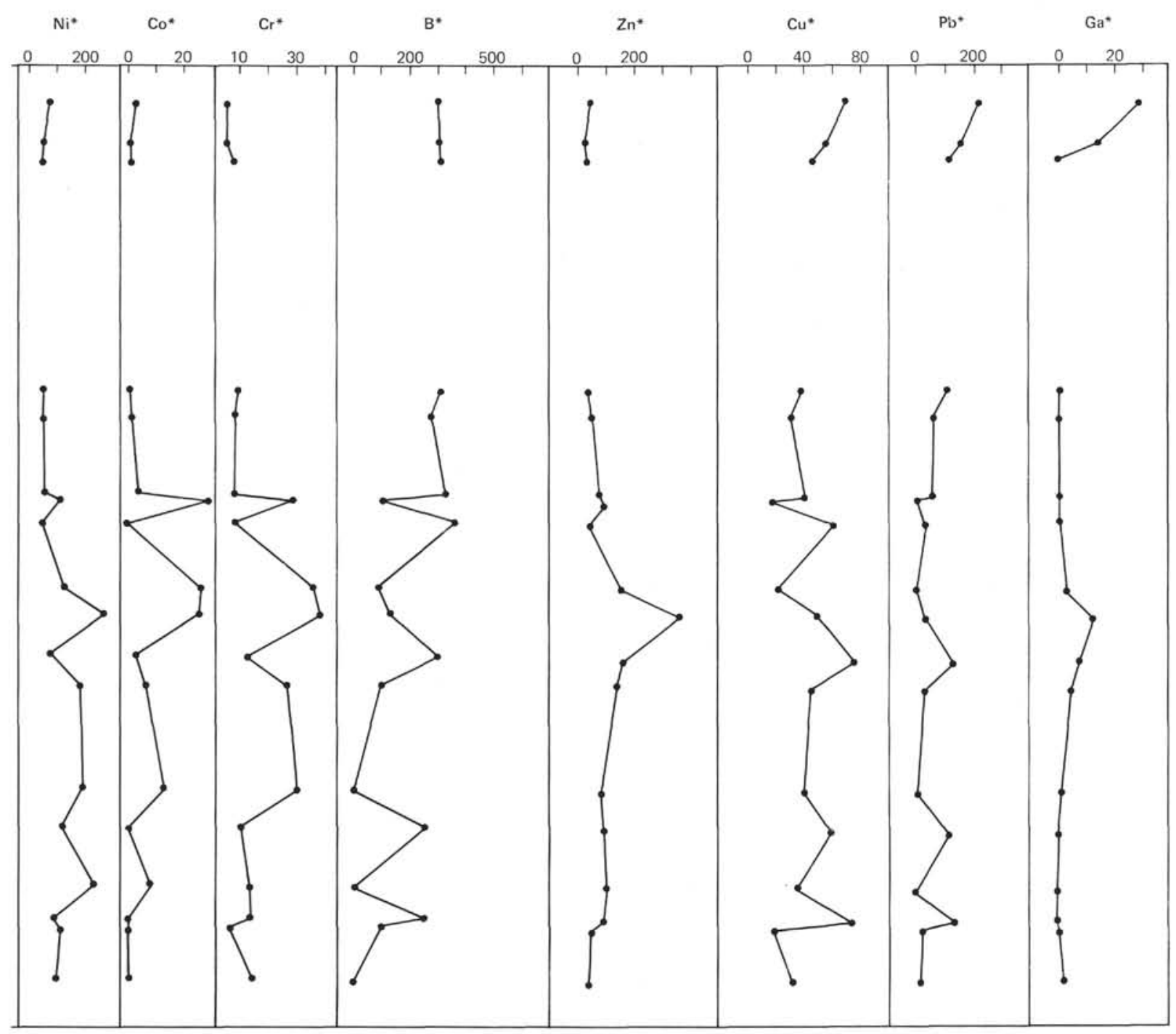

Figure 20. (Continued). 


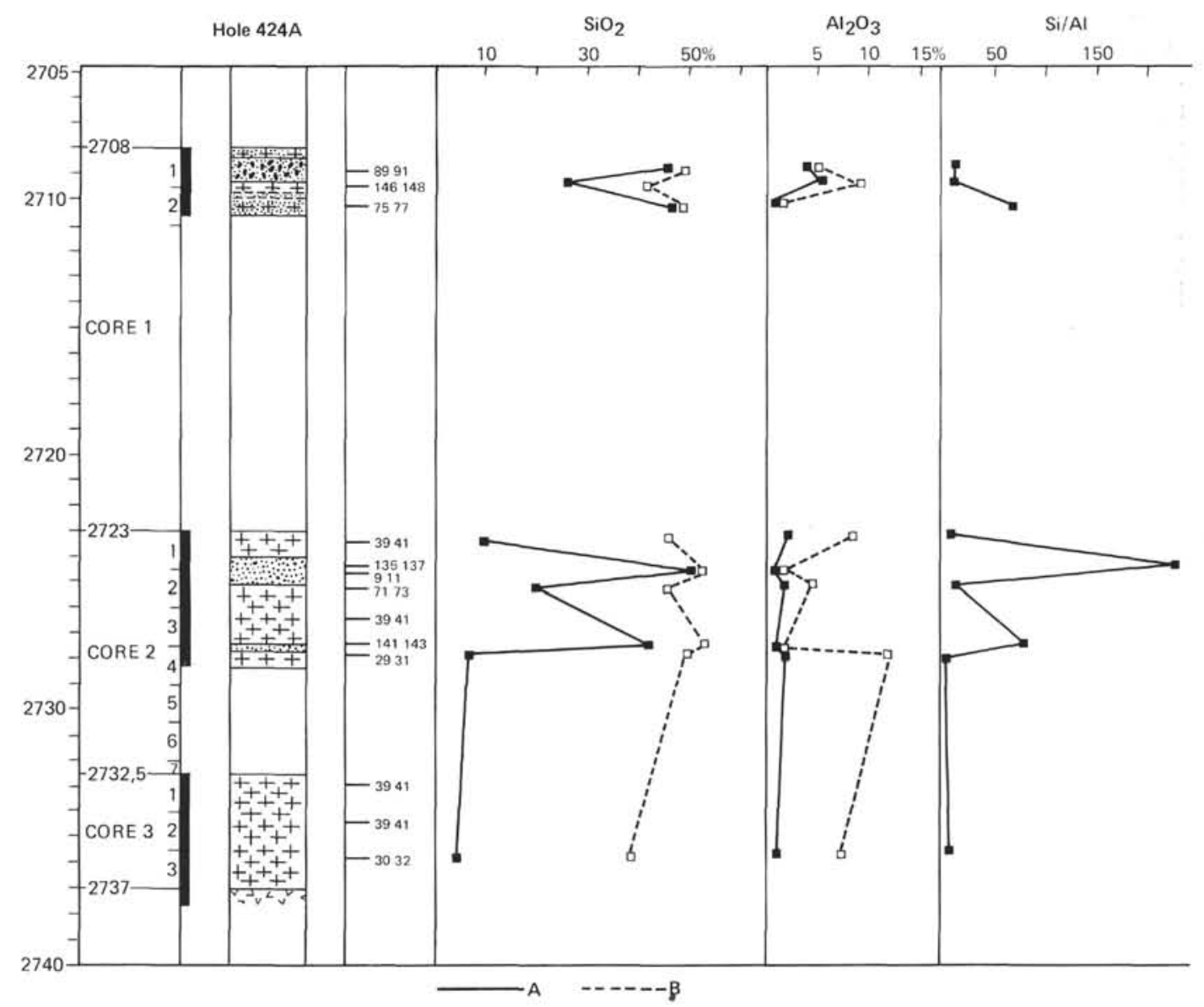

Figure 21. Variations of major oxides along Hole $424 \mathrm{~A}$. 
HYDROTHERMAL DEPOSITS

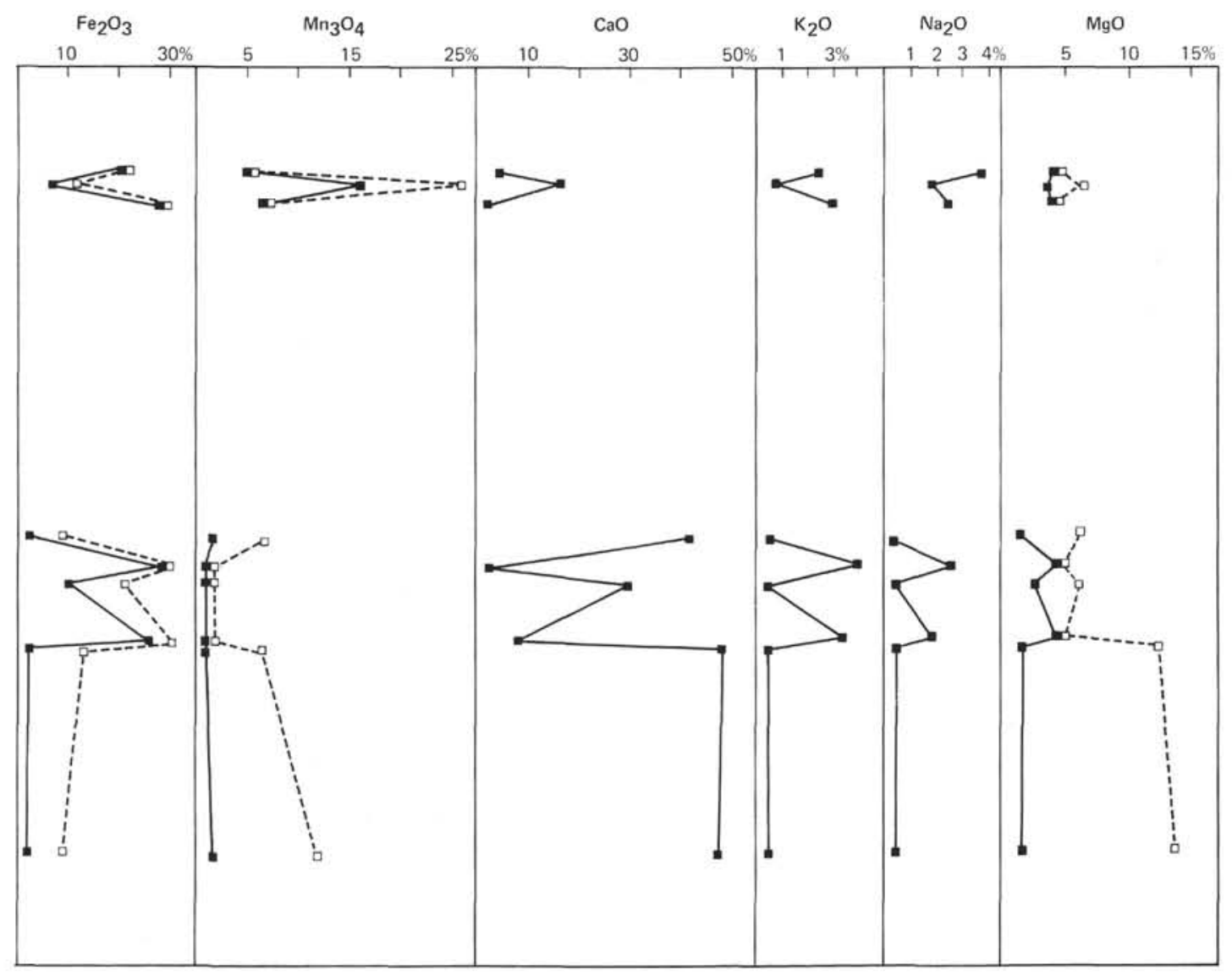

Figure 21. (Continued).

365 


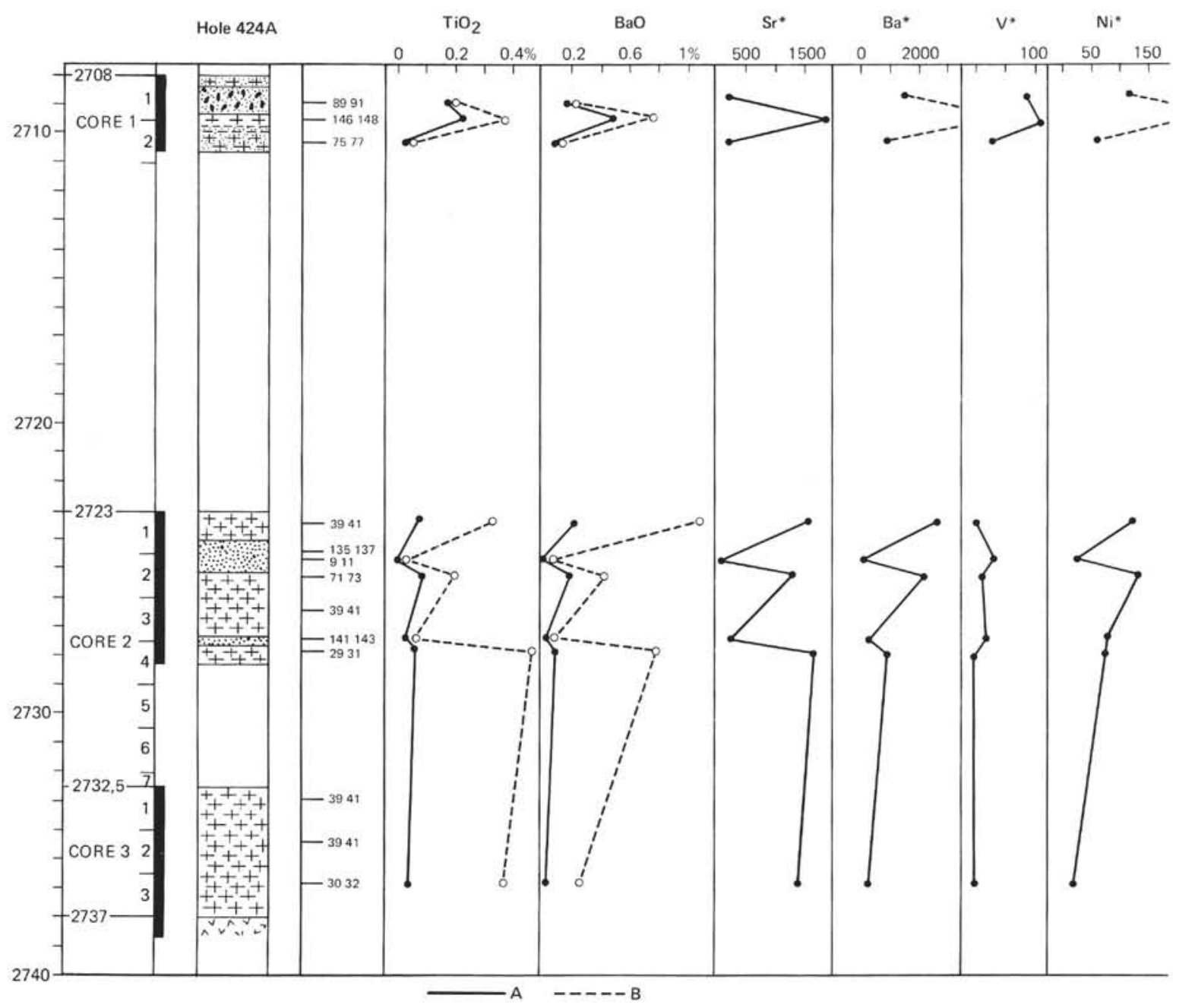

Figure 22. Variations of trace elements along Hole $424 \mathrm{~A}$. 


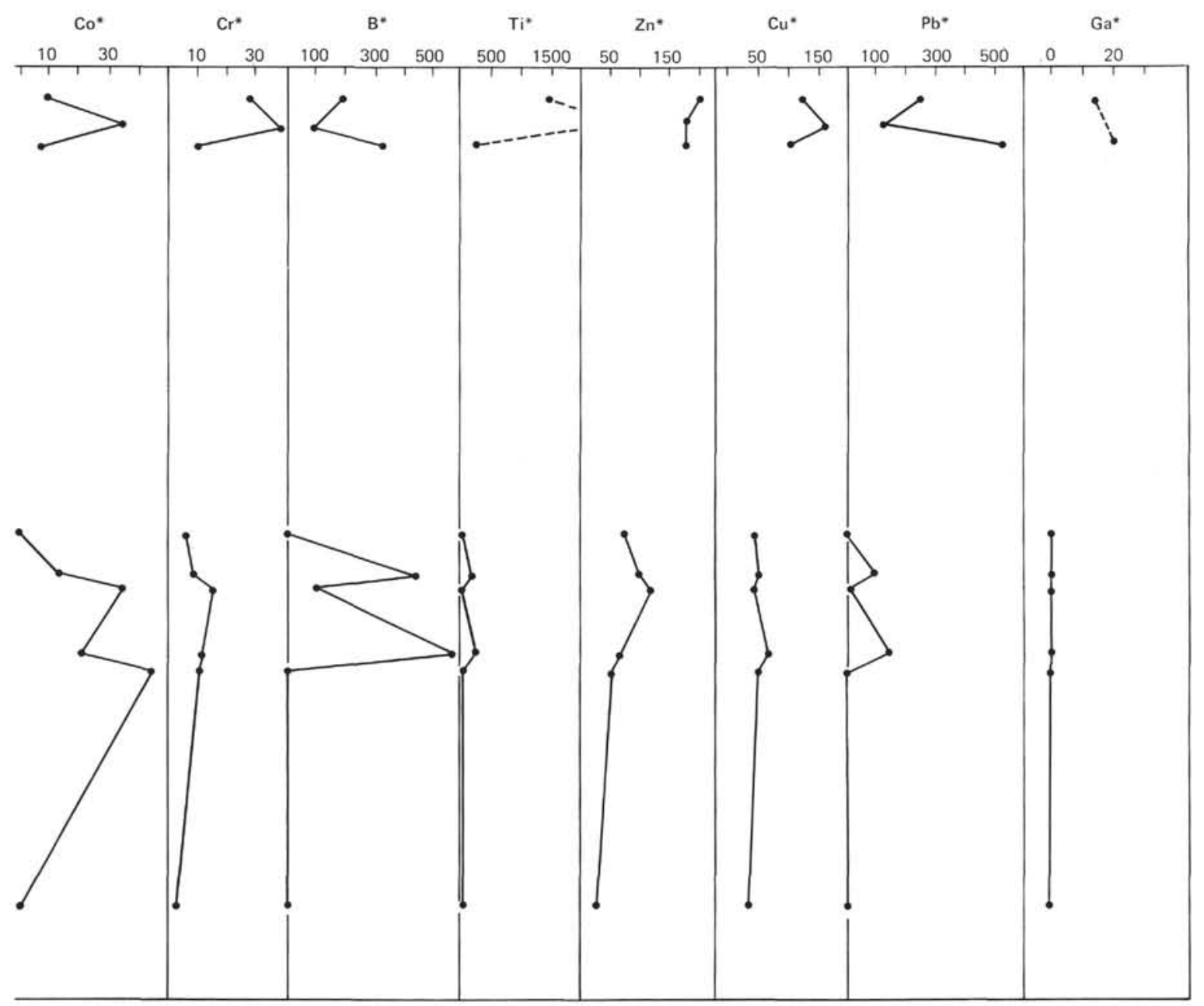

Figure 22. (Continued). 


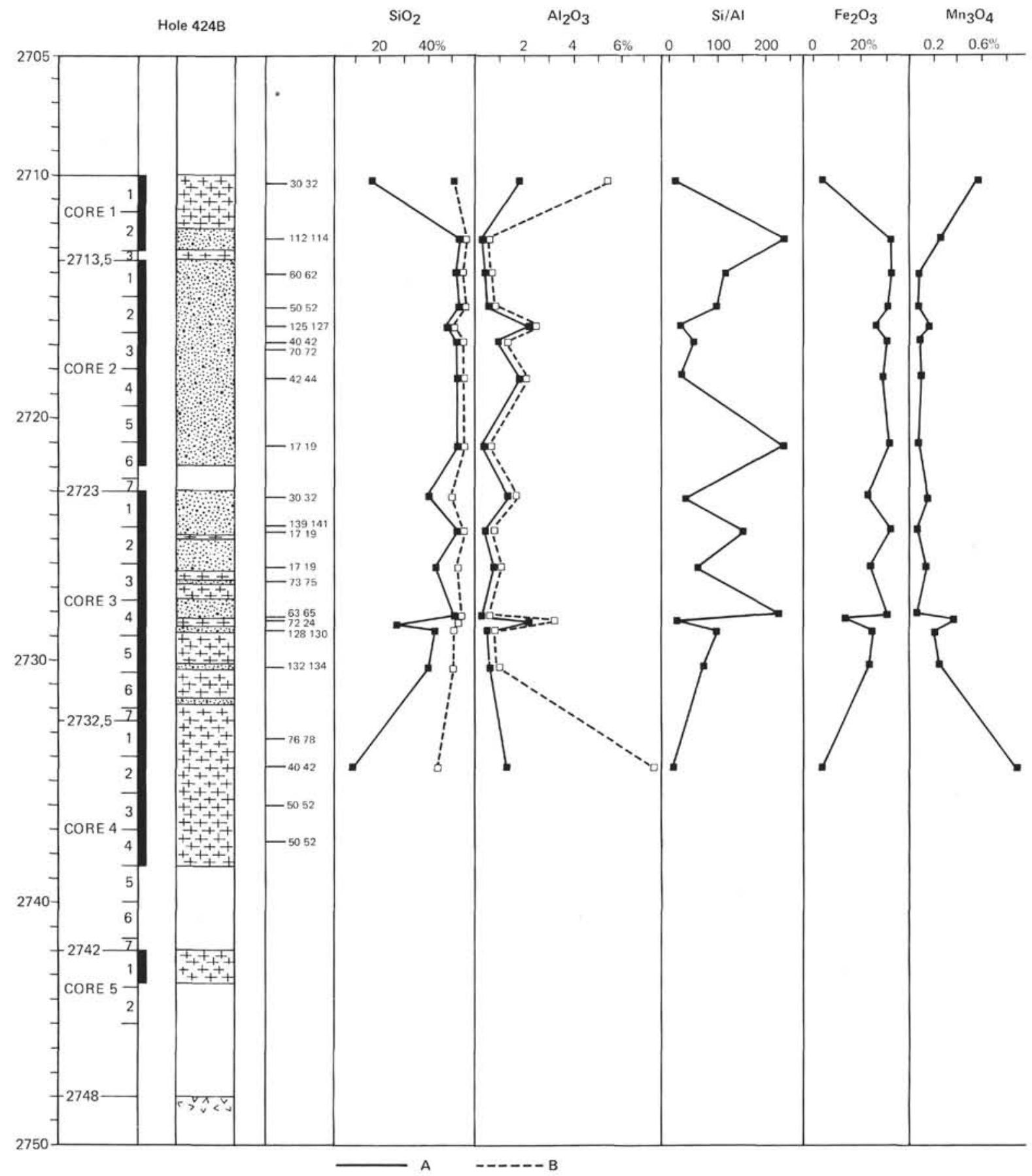

Figure 23. Variations of the major oxides along Hole 424B. 


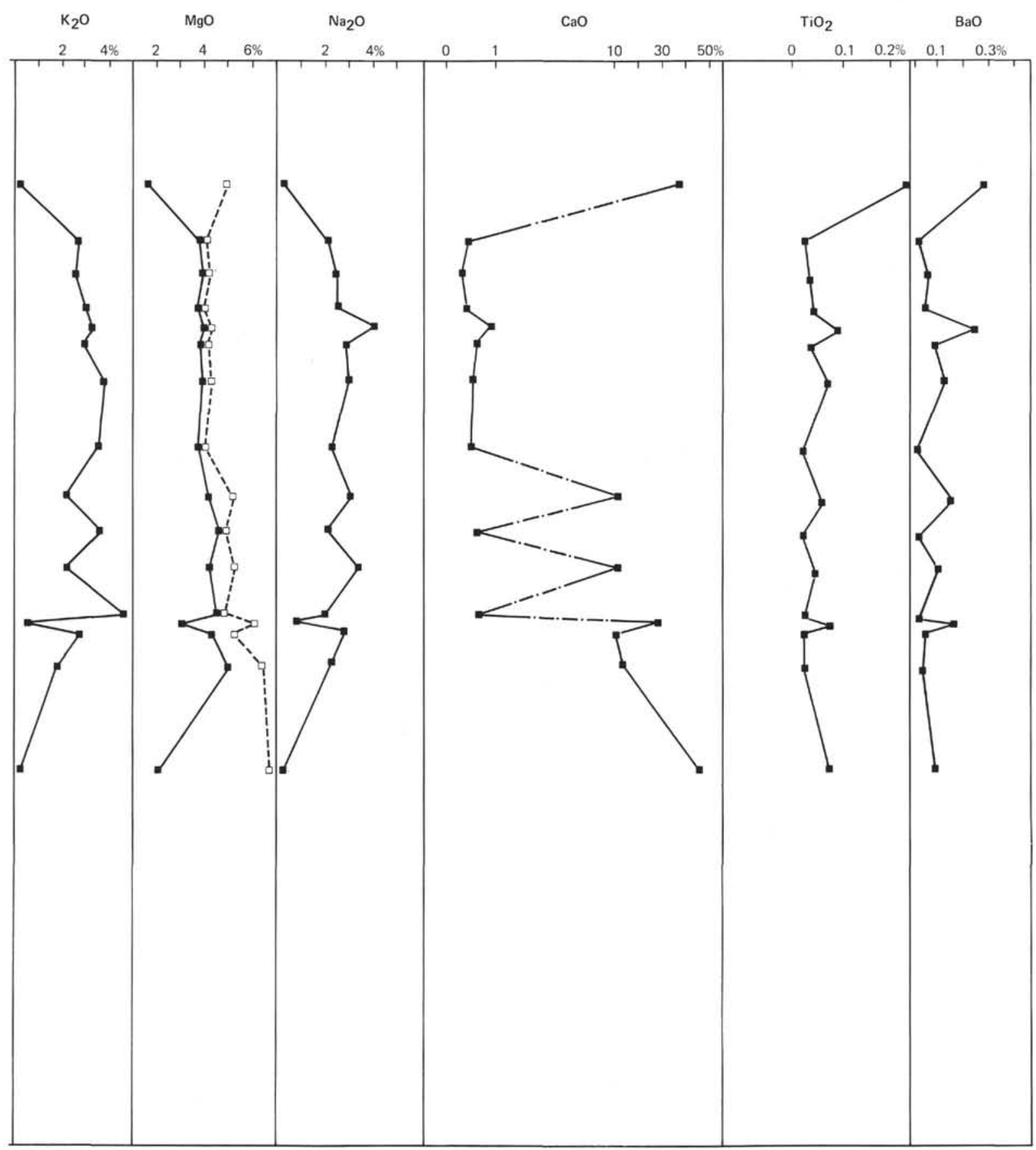

Figure 23. (Continued). 


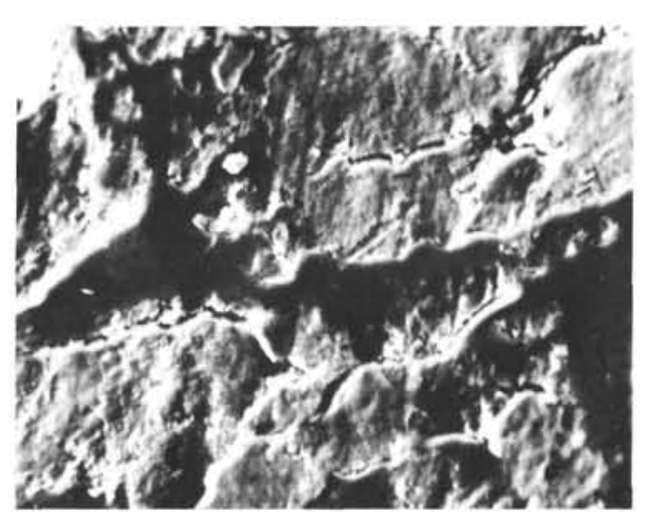

$\mathrm{Si}$

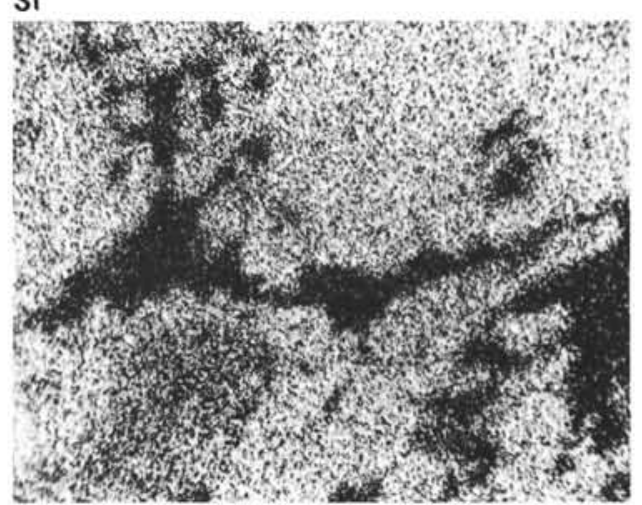

$\mathrm{Fe}$

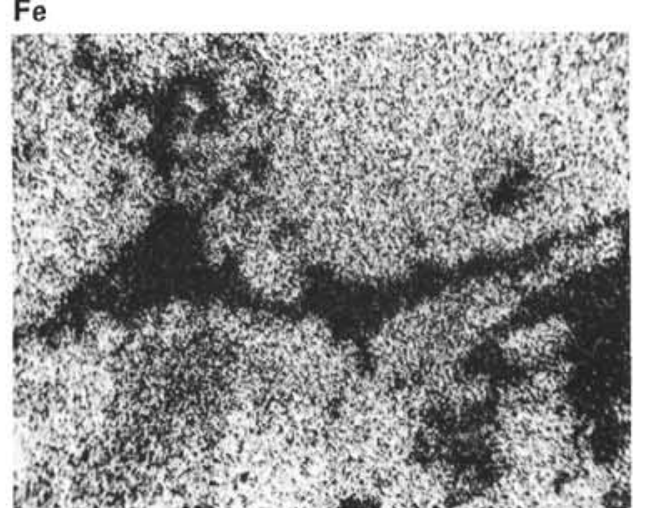

Sample 424B-2-6, 17-19
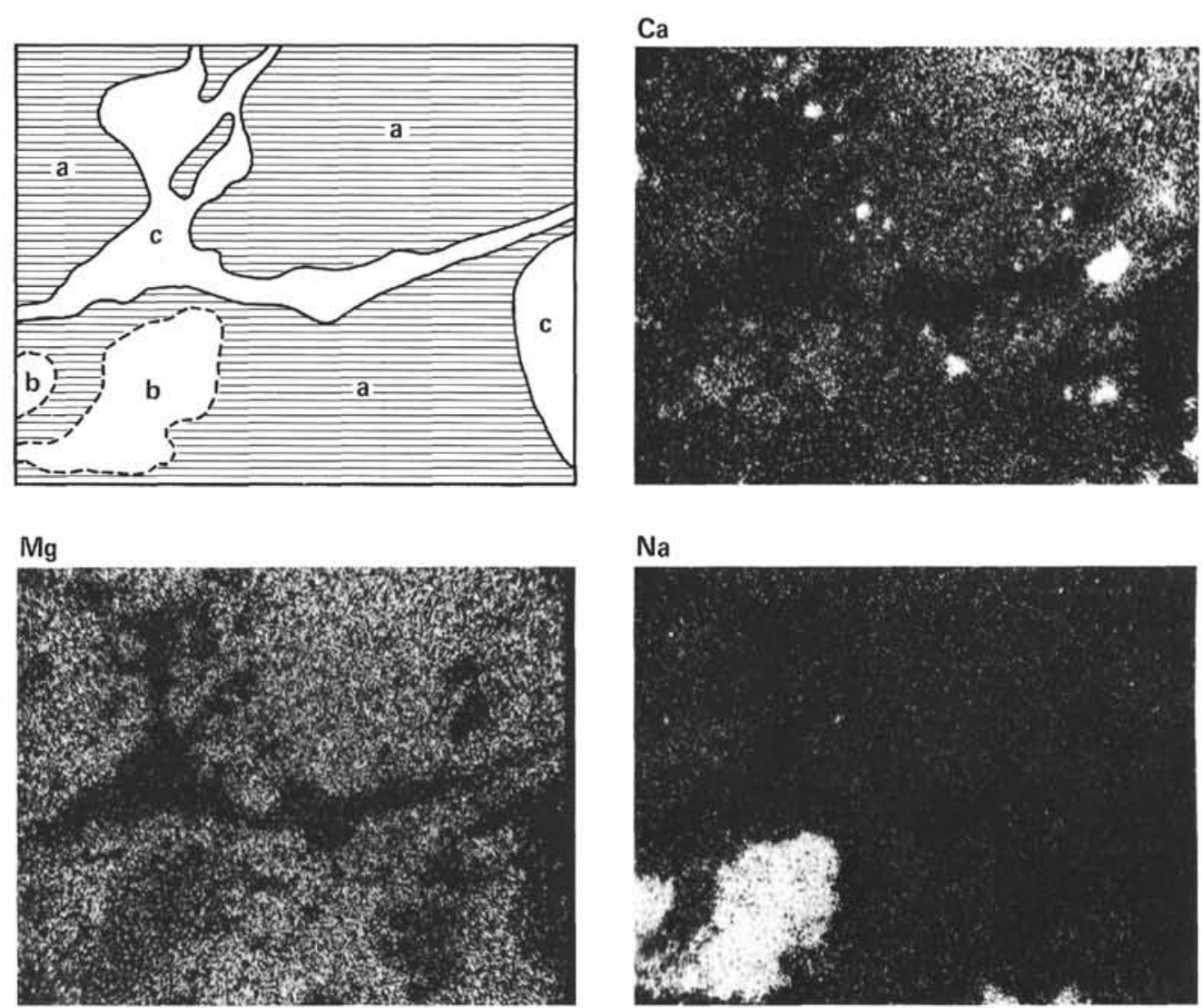

K

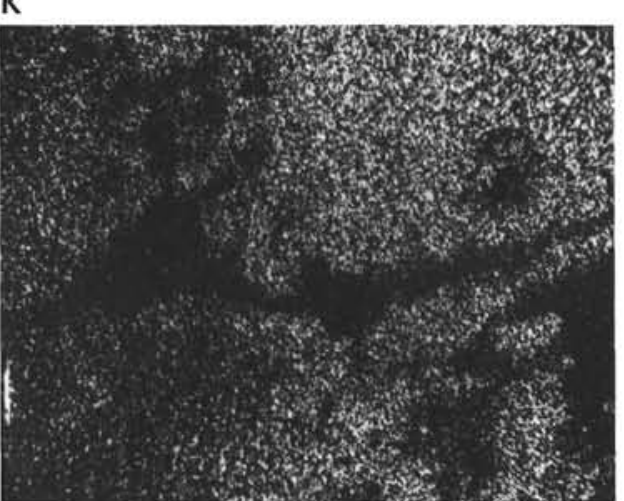

$\mathrm{Na}$

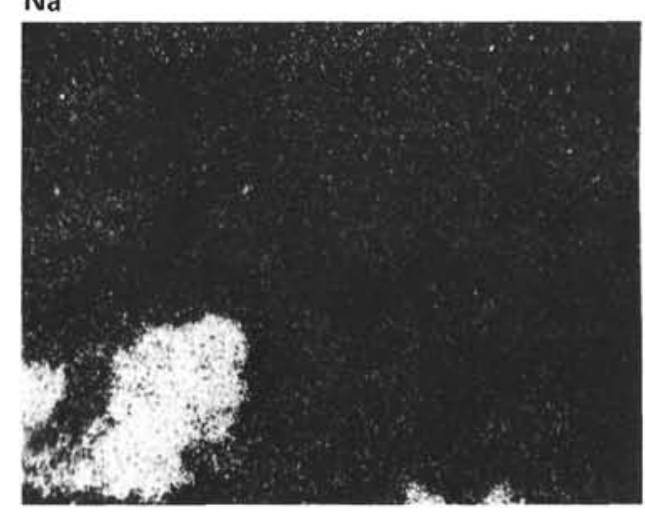

$\mathrm{Cl}$

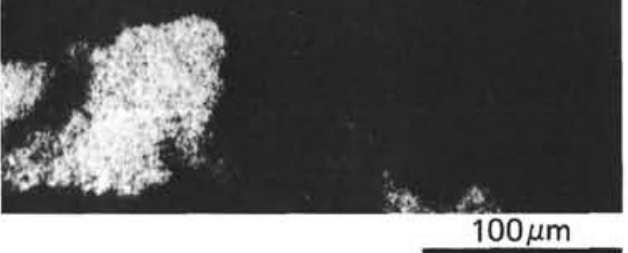

Figure 24. Distribution of certain elements from green, clay-rich particles obtained in SEM examination. 
TABLE 17

REE Concentrations (ppm), Hole 424, Leg 54

\begin{tabular}{lllllllllll}
\hline $\begin{array}{c}\text { Sample } \\
\text { Interval in cm) }\end{array}$ & $\mathrm{La}$ & $\mathrm{Ce}$ & $\mathrm{Nd}$ & $\mathrm{Sm}$ & $\mathrm{Eu}$ & $\mathrm{Tb}$ & $\mathrm{Yb}$ & $\mathrm{Lu}$ & TOTAL & $\mathrm{Ce} / \mathrm{Ce} *$ \\
\hline $1-1,89-91$ & 1.0 & 1.2 & 0.9 & 0.18 & 0.05 & 0.05 & 0.18 & 0.032 & 4 & 0.58 \\
$2-1,128-130$ & 0.40 & 0.76 & 0.42 & 0.10 & 0.03 & 0.03 & 0.32 & 0.06 & 2 & 0.87 \\
$2-3,67-69$ & 1.1 & 1.6 & 1.4 & 0.33 & 0.09 & 0.075 & 0.35 & 0.065 & 5 & 0.64 \\
$2-6,59-61$ & 8.9 & 9.3 & 9.1 & 1.89 & 0.52 & 0.41 & 1.53 & 0.28 & 32 & 0.51 \\
$3-1,42-44$ & 1.52 & 2.25 & 2.28 & 0.48 & 0.135 & 0.12 & 0.46 & 0.095 & 7 & 0.63 \\
$4-4,29-31$ & 6.6 & 7.4 & 6.2 & 1.2 & 0.31 & 0.29 & 1.08 & 0.195 & 23 & 0.56 \\
5-4, 2-5 (Piece 1) & 3.15 & 12.2 & 12.0 & 4.24 & 1.60 & 1.20 & 4.83 & 0.88 & 40 & \\
\hline
\end{tabular}

TABLE 18

REE Concentrations (ppm), Hole 424A, Leg 54

\begin{tabular}{lcccccccccc}
\hline $\begin{array}{c}\text { Sample } \\
\text { (Interval in cm) }\end{array}$ & $\mathrm{La}$ & $\mathrm{Ce}$ & $\mathrm{Nd}$ & $\mathrm{Sm}$ & $\mathrm{Eu}$ & $\mathrm{Tb}$ & $\mathrm{Yb}$ & $\mathrm{Lu}$ & $\mathrm{TOTAL}$ & $\mathrm{Ce} / \mathrm{Ce} *$ \\
\hline $1-1,89-91$ & 7.69 & 9.80 & 9.54 & 2.29 & 0.60 & 0.46 & 1.45 & 0.26 & 32 & 0.56 \\
$1-2,75-77$ & 0.90 & 1.13 & 1.10 & 0.22 & 0.05 & 0.04 & 0.185 & 0.035 & 4 & 0.57 \\
$2-2,9-11$ & 0.30 & 0.42 & 0.46 & 0.08 & 0.02 & 0.02 & 0.08 & 0.015 & 2 & 0.60 \\
$2-3,14-16$ & 0.58 & 1.0 & 0.45 & 0.09 & 0.02 & 0.015 & 0.08 & 0.016 & 2 & 1.0 \\
$2-4,29-31$ & 3.33 & 6.0 & 3.0 & 0.60 & 0.16 & 0.16 & 0.61 & 0.12 & 14 & 0.90 \\
$3-2,39-41$ & 4.50 & 4.60 & 5.0 & 0.80 & 0.21 & 0.17 & 0.80 & 0.15 & 16 & 0.48 \\
$4-1,3-5$ (Piece 1) & 3.40 & 11.80 & 12.75 & 4.30 & 1.75 & 1.32 & 5.36 & 0.98 & 42 & \\
\hline
\end{tabular}

TABLE 19

REE Concentrations (ppm), Hole 424B, Leg 54

\begin{tabular}{lccccccccrr}
\hline $\begin{array}{c}\text { Sample } \\
\text { (Interval in cm) }\end{array}$ & $\mathrm{La}$ & $\mathrm{Ce}$ & $\mathrm{Nd}$ & $\mathrm{Sm}$ & $\mathrm{Eu}$ & $\mathrm{Tb}$ & $\mathrm{Yb}$ & $\mathrm{Lu}$ & $\mathrm{TOTAL}$ & $\mathrm{Ce} / \mathrm{Ce}$ \\
\hline $1-2,112-114$ & 3.73 & 4.76 & 3.57 & 0.82 & 0.185 & 0.17 & 0.65 & 0.123 & 14 & 0.62 \\
$2-2,50-52$ & 0.75 & 0.81 & 0.89 & 0.22 & 0.05 & 0.05 & 0.16 & 0.03 & 3 & 0.49 \\
$2-2,125-127$ & 1.53 & 2.28 & 1.90 & 0.46 & 0.116 & 0.09 & 0.32 & 0.05 & 7 & 0.66 \\
$2-3,70-72$ & 8.20 & 11.85 & 10.5 & 2.61 & 0.65 & 0.515 & 1.63 & 0.28 & 36 & 0.65 \\
$2-4,42-44$ & 3.45 & 4.85 & 4.21 & 1.03 & 0.265 & 0.22 & 0.71 & 0.123 & 15 & 0.64 \\
$5-1,67-70$ (Piece 9) & 3.12 & 9.72 & 11.6 & 3.98 & 1.52 & 1.17 & 4.67 & 0.85 & 36 & \\
\hline
\end{tabular}

characterized by a depletion in the lightest rare earths, especially $\mathrm{La}$ and $\mathrm{Ce}$, and agree with the data of Schilling et al. (1976) for basalts dredged along the GSC. This light-REE-depleted pattern is typical of tholeiitic basalts from great ocean depths, and the samples show no sign of alteration which can sometimes disturb their initial REE location (Frey et al., 1974).

\section{In Sediments}

We studied two types of sediments: Type I and II hydrothermal deposits, on the one hand; type III foraminifer-nannofossil ooze, on the other hand. The REE content in dark green hydrothermal deposits is very low, of the order of a few ppm for the total of the elements analyzed in this study. These very low concentrations are surprising in view of the fact that these deposits are composed of argillaceous granules. (It is well known that these commonly contain a large quantity of trace elements, particularly REE.) The surface specimen, Sample 424A-1-1, 89-91 cm is an exception as it contains $32 \mathrm{ppm}$ of REE. This sample also contains more trace elements than the deeper sediments. The foramini- fer-nannofossil oozes have a REE concentration which is five to 10 times higher than that of hydrothermal deposits.

To compare these deposits with other types of marine sediments, REE distribution curves were established by normalization to an average value of shales (Haskin and Haskin, 1966); they are reported in Figures 26 through 31.

The REE distribution curves of hydrothermal deposits are regular and show two principal characteristics:

A negative $\mathrm{Ce}$ anomaly which is constant in intensity $\left(\mathrm{Ce} / \mathrm{Ce}^{*}\right.$ ratio between 0.50 and $0.65, \mathrm{Ce}^{*}$ being the interpolated value between $\mathrm{La}$ and $\mathrm{Nd}$ as if there were no anomaly) in most of the studied samples.

An important fractionation marked by an enrichment of the heavy REE in relation to the lightest REE. In addition, $\mathrm{La}$ is often at lower values than $\mathrm{Nd}$. The distribution of REE in sea water is characterized by an important negative $\mathrm{Ce}$ anomaly $\left(\mathrm{Ce} / \mathrm{Ce}^{*}=0.18\right)$ and an enrichment in heavy REE in relation to light ones (Høgdahl et al., 1968). Thus, the REE patterns of the hydrothermal deposits resemble those of sea water, but the $\mathrm{Ce}$ anomaly is less pronounced and $\mathrm{La}$ is more de- 


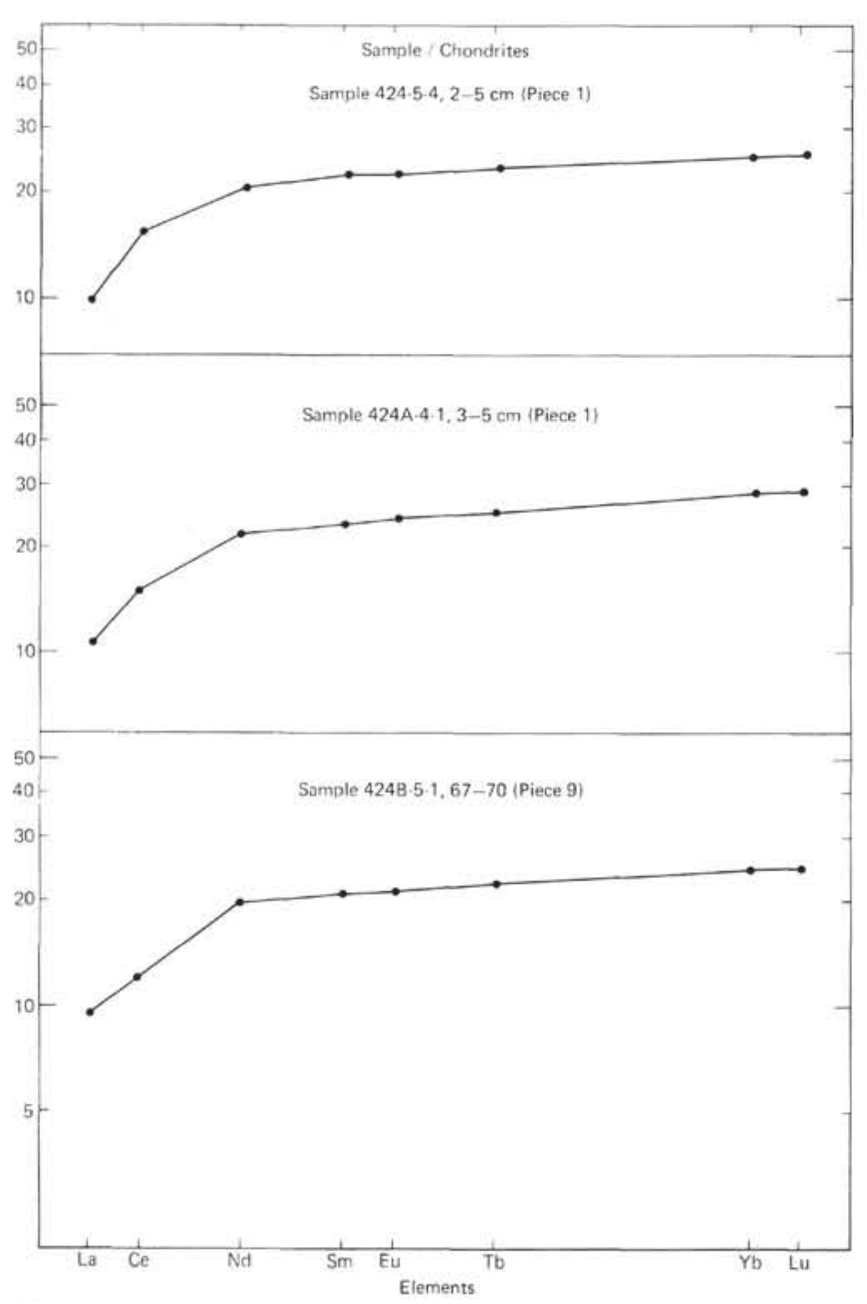

Figure 25. REE abundance patterns of basalts.

pleted than in the sea water pattern, where it is at the same level as Nd. The REE distribution curves of basalts, as compared with shales, are highly fractionated, with an important depletion in the lightest REE, especially $\mathrm{La}, \mathrm{Ce}, \mathrm{Nd}$, and $\mathrm{Sm}$. So, it is possible that the influence of the basalt can be seen in the low proportion of light REE, especially La. Sea water can induce the negative $\mathrm{Ce}$ anomaly and the enrichment in heaviest REE.

The REE distribution curves in foraminifer-nannofossil ooze are similar to those of hydrothermal deposits, but the enrichment in heavy REE is slight, and there is no depletion of La with respect to Nd. This type of distribution and the absolute REE contents can be seen in "classical" carbonate oozes (Spirn, 1965; Piper, 1974; Courtois and Hoffert, 1977).

In conclusion, we note that the main characteristic of this type of hydrothermal deposit is its very low REE content. This is in contrast to the high trace-element concentrations (with REE values of several hundreds of $\mathrm{ppm}$ ) found in deep-sea brown muds from, for example, the EPR (Piper and Graef, 1974; Courtois and Hoffert, 1977). The REE distribution curves of Leg 54 hydrothermal deposits are characterized by an important enrichment in heavy REE and a slight negative Ce anoma-

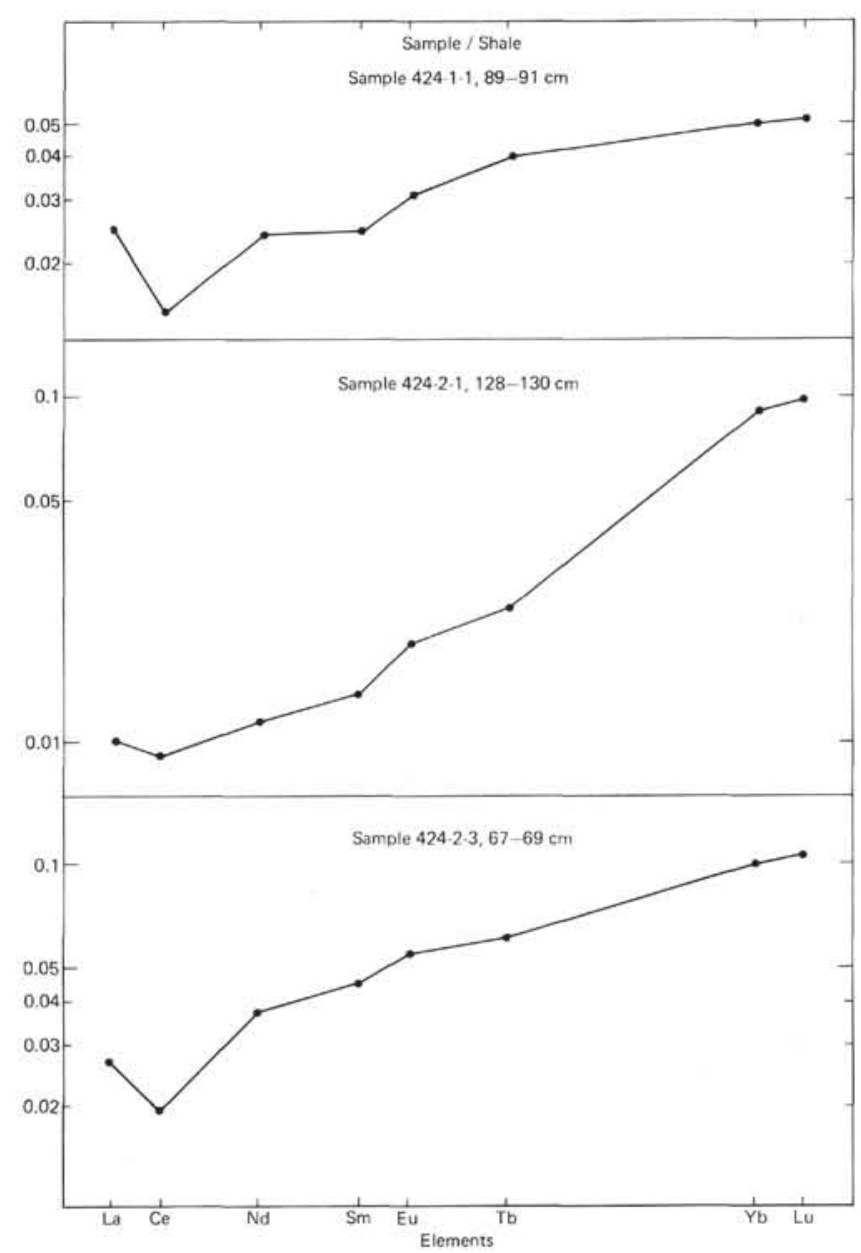

Figure 26. REE abundance patterns of sediment (Hole 424).

ly, which may possibly reflect a mixed influence of basalt and sea water.

\section{CONCLUSION}

The principal results are the following:

Hydrothermal deposits are of two types, depending upon whether or not the basic unit - a dark green granule - contains manganese oxyhydroxides.

The dark green granule is characterized by a chemical composition which is $\mathrm{Si}-\mathrm{Fe}$ rich and $\mathrm{Al}$-poor. $\mathrm{K}$ and $\mathrm{Mg}$, in lesser amount, are also present. Trace elements and REE are present in low concentrations. The mineralogical investigation indicates a smectite type of structure for this clay.

From textural and mineralogical studies, two types of clays may be distinguished: (1) an Fe-beidellite with a lath-like morphology, and (2) a glauconite-celadonite type of material with ringlet-like morphology characterized by a near $10 \AA$ basal peak.

$\mathrm{Mn}$ is present in different forms: as oxyhydroxides and as well-crystallized todorokite which differs from hydrogenous todorokite. The deposit of Mn should be later in respect to smectitic material and near the water/ sediment interface. 


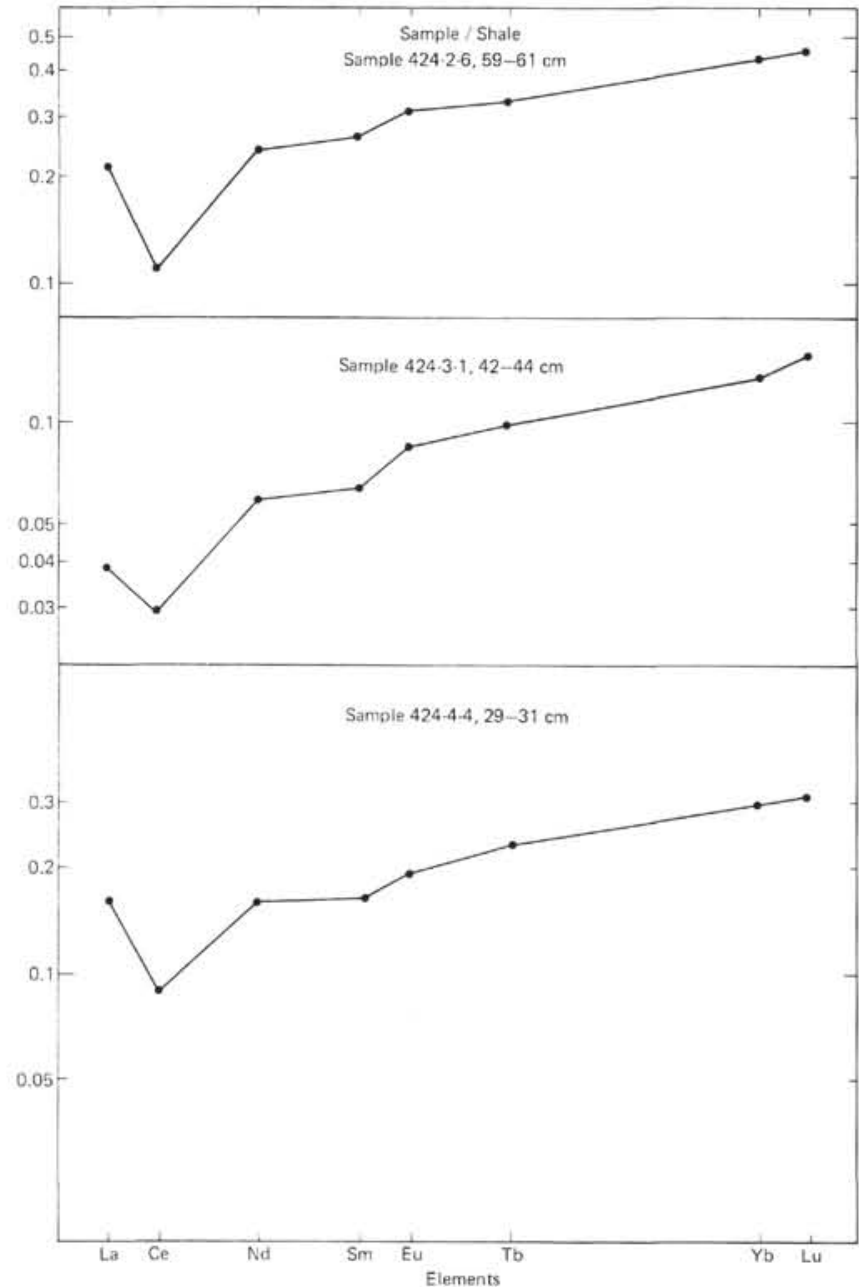

Figure 27. REE abundance patterns of sediment (Hole 424).

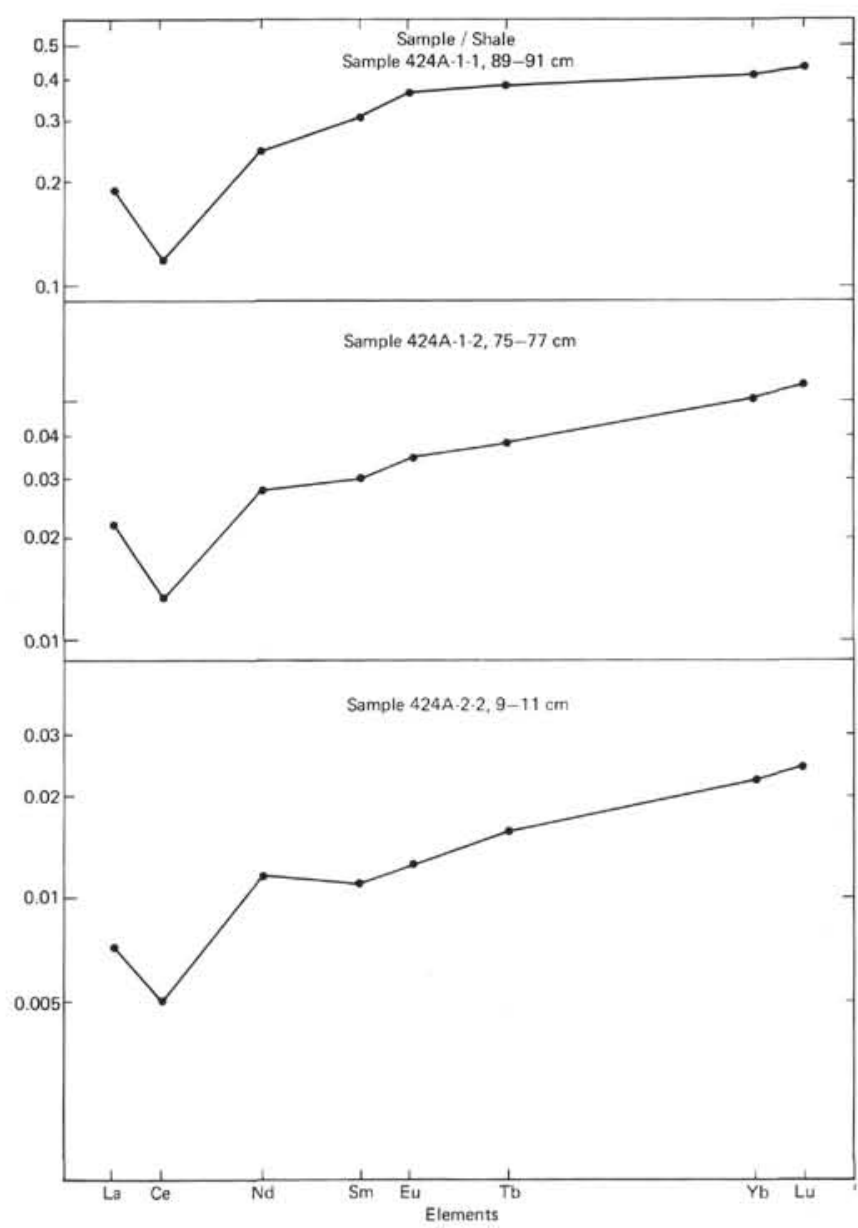

Figure 28. REE abundance patterns of sediment (Hole $424 A)$. 


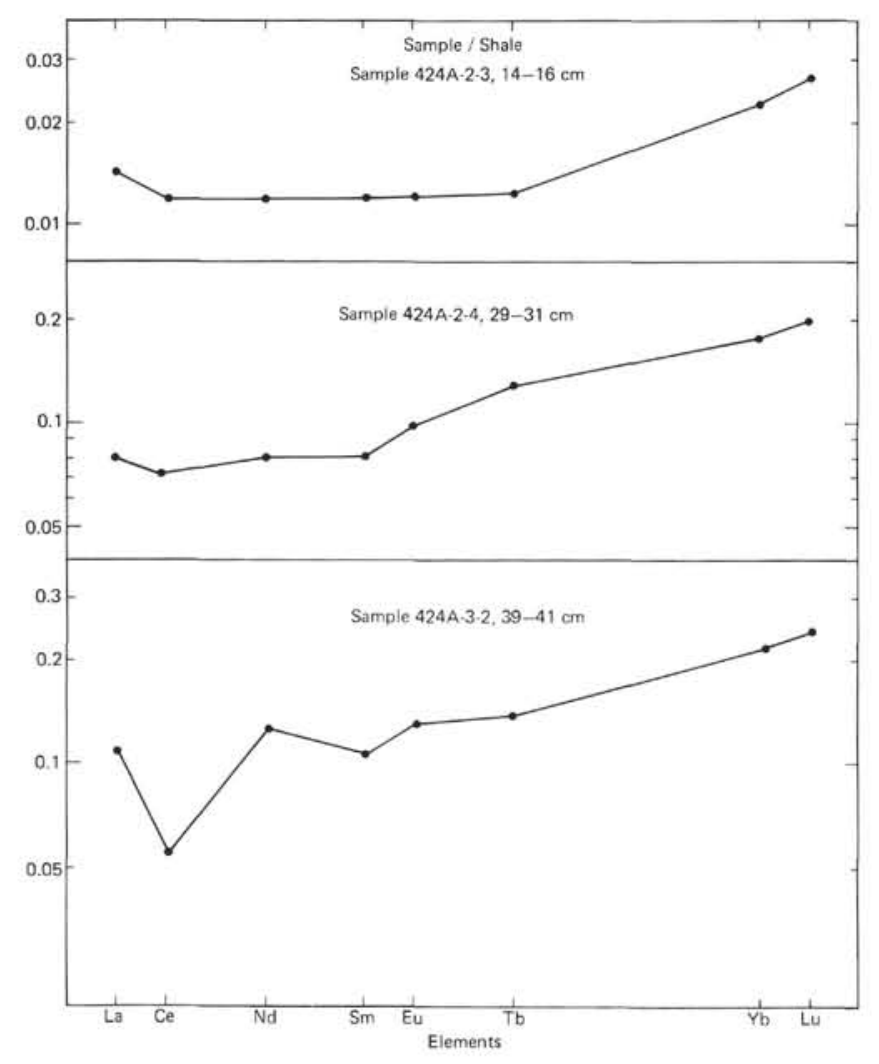

Figure 29. REE abundance patterns of sediment (Hole $424 A)$.

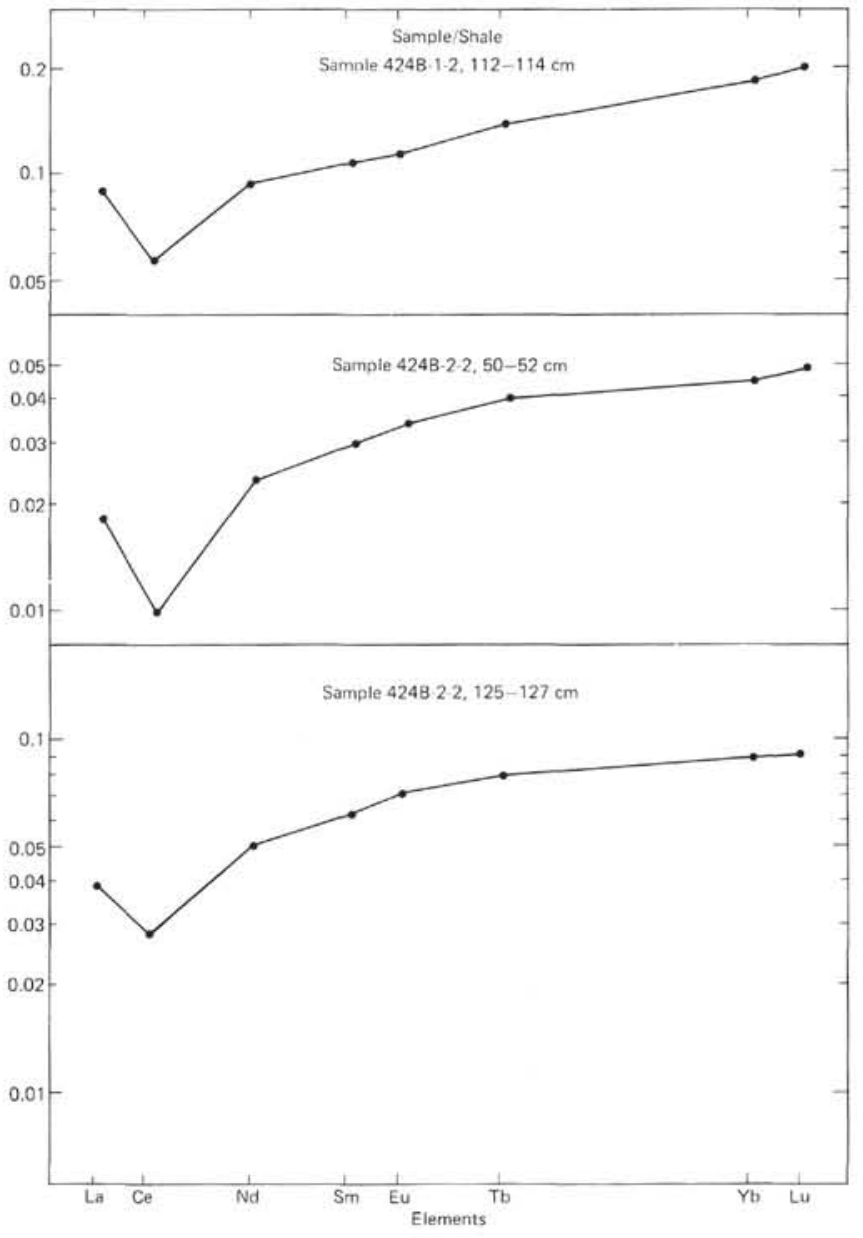

Figure 30. REE abundance patterns of sediment (Hole $424 B)$. 


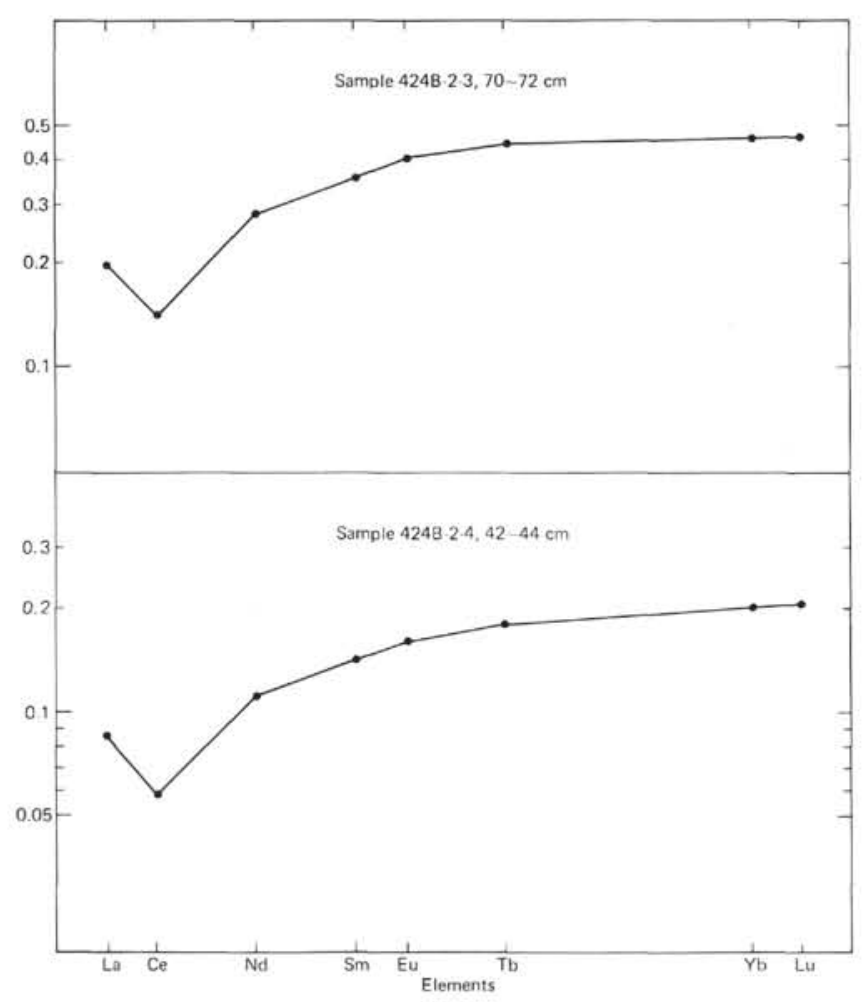

Figure 31. REE abundance patterns of sediment (Hole $424 B)$.

Further results are:

Amorphous silica must be present as indicated by X-ray diagrams.

Organisms seem to be instable in this environment.

The foraminifer-nannofossil ooze has a clay mineral composition which differs from most of the Panama Basin sediments. These clay minerals seem also instable in this environment.

The REE study indicates that the material giving rise to hydrothermal deposits has a mixed origin: basalt and sea water.

Therefore, the hydrothermal deposits have definite mineralogical and geochemical characteristics and appear also as an instable environment in which alterations, transformations, and neoformations occur.

\section{REFERENCES}

Ataman, G., 1964. Oligoéléments dans les argiles. Revue I.F.P. v. 19, No. 9, p. 958-969.

Besnus, Y. and Lucas, J., 1968. Méthode de dosage de 18 éléments majeurs et traces dans les roches sedimentaires et les produits d'altération par spectrométrie à lecture directe. Colloques Nat, du CNRS, Paris, v.923, p. 93-106.

Besnus, Y. and Rouault, R., 1973. Une methode d'analyse des roches au spectromètre d'arc à lecture directe par un dispositif d'électrode rotative. Analusis, v. 2, p. 111-116.

Brongersma-Sanders, M., 1967. Barium in pelagic sediments and in diatoms. Nederl. Akad. Wetersch. Proc., v. B, p. 93-99.
Corliss, J. B., Lyle, M., Dymond J. and Crane K., 1978. The chemistry of hydrothermal mounds near the Galapagos Rift. Earth Planet. Sci. Let. v. 40, p. 12-24.

Courtois, C. and Hoffert, M., 1977. Distribution des terres rares dans les sédiments superficiels du Pacifique Sud Est. Bull. Soc. Géol. Fr., v. 7, p. 1245-1252.

Crane, K. and Normark, W. R., 1977. Hydrothermal activity and crestal structure of the East-Pacific Rise at $21^{\circ} \mathrm{N}$. $J$. Geophys. Res., v. 82, No. 33, p. 5336-5348.

El Wakeel, S. K. and Riley, J. P., 1961. Chemical and mineralogical studies of deep-sea sediments. Geochim. Cosmochim. Acta, v. 25 , p. $110-146$.

Frey, F. A., Bryan, W. B., and Thompson, G., 1974. Atlantic Ocean floor: geochemistry and petrology of basalts from Leg 2 and 3 of the Deep Sea Drilling Project. $J$. Geophys. Res., v. 79, p. 5507-5527.

Glasby, G. P., 1978. Marine manganese deposits. Elsevier Ocean Ser. v. 15.

Haskin, M. A. and Haskin, L. A., 1966. Rare earths in European shales: a redetermination. Science, v. 154, p. 507-509.

Heath, G. R., Moore, T. C., and Roberts, G. L., 1974. Mineralogy of surface sediments from the Panama Basin, Eastern Equatorial Pacific. J. Geol., v. 82, p. 145-160,

Hekinian, R., Rosendahl, B. R., Cronan, D. S., Dmitriev, Y., Fodor, R. V., Goll, R. M., Hoffert, M., Humphris, S. E., Mattey, D. P., Natland, J., Petersen, N., Roggenthen, W., Schrader, E. L., Srivastava, R. K., and Warren, N., 1978. Hydrothermal deposits and associated basement rocks from the Galapagos Spreading Center. Oceanologica Acta, v. 1, p. $473-482$.

Hoffert, M., Perseil, A., Hekinian, R., Choukroune, P., Needham, H. D., Francheteau, J., and Le Pichon, X., 1978. Hydrothermal deposits sampled by diving saucer in transform fault " A" near $37^{\circ} \mathrm{N}$ on the Mid-Atlantic Ridge, FAMOUS area. Ibid., p. 73-86.

Høgdahl, O. T.. Melson. S., and Bowen. V.. 1968. Neutron activation analysis of lanthanide elements in seawater. $A d v$. Chem. Ser., v. 73, p. 308-325.

Karpoff, A. M., Bocquier, G., Isnard, P., and Tardy, Y., 1973. Géochimie d'une toposéquence de sols tropicaux du Tchad. Utilisation des méthodes statistiques. Sci. Geol. Bull., v. 26 (4), p. $315-338$.

Klitgord, K. D. and Mudie, J. D., 1974. The Galapagos Spreading Center: A near bottom geophysical survey. GeoPhys, J. Roy Astron. Soc., v. 38, p. 563-586.

Lonsdale, P., 1977. Deep-tow observations at the mounds abyssal hydrothermal field, Galapagos Rift. Earth Planet. Sci. Lett., v. 36 , p. $92-110$.

Odin, G. S., 1975. Les glauconies-constitution, formation, age. Thèse Doc. d'État. Université P. et M. Curie, Paris.

Person, A., 1976. Recherches sur les néoformations argileuses dans l'environnement volcanique. Thèse Sc. Paris.

Piper, D. Z., 1974. Rare earth elements in the sedimentary cycle: summary. Chem. Geol., v. 14, p. 285-304.

Piper, D. Z. and Graef, P. A., 1974, Gold and rare earth elements in sediments from the East Pacific Rise. Mar. Geol., v. 17 , p. $287-297$.

Schilling, J. G., Anderson, R. N., and Vogt, P., 1976. Rare earth, $\mathrm{Fe}$ and $\mathrm{Ti}$ variations along the Galapagos spreading center, and their relationship to the Galapagos mantle plume. Nature, v. 261, No. 5556, p. 108-113.

Spirn, R. V., 1965. Rare earth distributions in the marine environment. Ph.D. Thesis, M.I.T. Department of Geology and Geophysics, Cambridge, Mass. 
Straczek, J. A., Horen, A., Ross, M., and Warshaw, C. M., 1960. Studies of the manganese oxides. IV. Todorokite. Amer. Min., v. 45, p. 1174-1184.

Treuil, M., Jaffrezic, H., Deschamps, N., Derre, C., Guichard, F., Joron, J. L., Pelletier, B., Courtois, C., and Novotny, S., 1973. Analyse des lanthanides du hafnium, du scandium, du chrome, du manganese, du cobalt, du cuivre et du zinc dans les minéraux et les roches par activation neutronique. J. Radioanal. Chem.,v. 18, p. 55-68.
Trichet, J., 1970. Contribution à l'étude de l'alteration expérimentale des verres volcaniques. Travaux du Laboratoire de Géologie E.N.S., No. 4.

Williams, D. L., von Herzen, R. P., Sclater, J. G., and Anderson, R. N., 1974. The Galapagos Spreading Center: lithospheric cooling and hydrothermal circulation. Geophys. J. Roy. Astron. Soc., v. 38, p. 587-608. 